\title{
Ontwikkelingscheque Uitwerking Advies Denktank Leren en Werken
}

Gerla van Breugel

Andries de Grip

Dieter Dohmen (FiBS)

ROA-R-2011/3 
Colofon

(C) Researchcentrum voor Onderwijs en Arbeidsmarkt (ROA). Niets uit deze uitgave mag op enige manier worden verveelvoudigd zonder voorafgaande schriftelijke toestemming van de directeur van het ROA.

\section{Researchcentrum voor Onderwijs en Arbeidsmarkt}

School of Business and Economics

Maastricht University

\section{Vormgeving}

ROA secretariaat, Maastricht

\section{Verkoop}

Researchcentrum voor Onderwijs en Arbeidsmarkt email: secretary-roa-sbe@maastrichtuniversity.nl website: www.roa.nl

ISBN: 978-90-532I-494-7

april $201 \mathrm{I}$ 


\section{Inhoud}

Voorwoord

Resumé

$\mathbf{v}$

vii

I Inleiding

I.I Achtergrond onderzoek

I.2 Onderzoeksopzet

I.3 Leeswijzer

I

2

2 Het individuele leerbudget: leren van het verleden 5

2.I Endowment en labeling 5

2.2 Pilotprojecten van bedrijven $\quad 7$

2.2.I Het individueel inzetbaarheidbudget van KPN 8

2.2.2 Het employabilitybudget van ING IO

2.2.3 De E(mployability)-miles van Philips II

2.2.4 Persoonlijk Ontwikkelings Budget (POB) van Shell I2

2.2.5 Individueel Opleidingsbudget (IOB) van MSD I3

2.2.6 Samenvatting $\quad$ I4

2.3 Pilotprojecten van overheden en sociale partners $\quad$ I4

2.3.I Leerbon van de provincie Noord-Brabant 20

2.3.2 Ontdekcheque in de Metalektro 2I

2.3.3 Leertegoedbon in de Metaalbewerking 22

2.3.4 Experiment Individuele Leerrekening AGF/CKO 23

2.3.5 Experiment Individuele Leerrekening RBO Groningen 25

2.3.6 WeGebAU, stimulering door het federale arbeidsbureau (Duitsland) 26

2.3.7 Bildungsscheck Nordrhein-Westfalen (Duitsland) 27

2.3.8 Individual Learning Accounts, ILAs (Verenigd Koninkrijk) 28

2.3.9 Individual Learning Accounts, ILAs (Wales) 29

2.3.IO Individuele leerrekeningen Vlaanderen (België) 30

2.3.II Trainingscheques Vlaanderen (België) 30

2.3.I2 Scholingsrekeningen en vouchers van de deelstaten

(Oostenrijk) 3I

2.3.I3 Scholingsvouchers van de werknemerskamers 32

2.3.I4 Geneefs scholingsvouchermodel (Zwitserland) 33

2.3.I5 Voucherexperiment (Zwitserland) 34 
2.3.I6 Samenvatting

3 Lessen uit de theorie en de pilotprojecten:

Leerpunten voor de Ontwikkelingscheque $\quad 37$

3.I Het proces: hoe leerpunten te destilleren uit de praktijk 37

3.2 Beschrijving 38

3.3 Uitvoering en beheer 39

3.4 Communicatie en begeleiding 4I

3.5 Financiering 42

4 Uitvoeringsmodel Ontwikkelingscheque 43

4.I Het model 43

4.I.I Beschrijving 44

4.I.2 Uitvoering en beheer 45

4.I.3 Communicatie en begeleiding 46

4.2 Specifiek model voor de doelgroep werknemers zonder startkwalificatie

4.2.I Uitvoering en beheer $\quad 47$

4.2.2 Communicatie en begeleiding $\quad 48$

4.3 Financiering en verwachte kosten 49

4.4 De eerste stap $\quad 52$

Bijlagen $\quad 55$

Tabel BI
Eerste inventarisatie van individuele leerbudgetten buiten Nederland

Tabel B2

Eerste inventarisatie van individuele leerbudgetten in Nederland 60

$\begin{array}{ll}\text { Overzicht experts } & 65\end{array}$

Tabel B 3

Budgettair beslag van huidige maatregelen in 2010

66 


\section{Voorwoord}

In juli 2009 bracht de door de Ministeries van SZW en OCW geïnstalleerde Denktank Leren en Werken haar advies Tijd voor ontwikkeling uit. In dit advies deed de Denktank een aantal voorstellen voor een strategie om het leven lang leren in Nederland meer van de grond te krijgen. Eén van deze voorstellen was het invoeren van een opleidingscheque. In dit onderzoeksrapport wordt dit voorstel nader uitgewerkt op basis van een verkenning van de resultaten van eerdere binnenlandse en buitenlandse experimenten met opleidingscheques en gesprekken met deskundigen.

De auteurs van dit rapport willen een aantal personen die aan de totstandkoming van dit rapport hebben meegewerkt, bedanken. In de eerste plaats dhr. Toon Janssen die namens de projectdirectie Leren en Werken dit onderzoek heeft begeleid. Daarnaast willen we de sleutelpersonen van de sociale partners waarmee we gesproken hebben en de Nederlandse en buitenlandse experts die ervaring hebben met eerdere opleidingschequeprojecten, bedanken voor hun waardevolle feedback op het door ons uitgewerkte voorstel voor een Ontwikkelingscheque. 



\section{Resumé}

De Denktank Leren en Werken vindt dat het leven lang leren van werkend Nederland tot op heden onvoldoende van de grond komt. In haar advies Tijd voor ontwikkeling draagt zij een aantal voorstellen aan die het postinitiële leren in Nederland een positieve stimulans kunnen geven. Eén van deze voorstellen is het invoeren van een opleidingscheque. Een opleidingscheque is een vorm van een individueel leerbudget waarbij het individu een bedrag ontvangt, dat naar eigen inzicht aan leeractiviteiten besteed mag worden. Dit roept de vraag op hoe een dergelijke opleidingscheque er uit zou moeten zien, om er voor te zorgen dat werkenden daadwerkelijk meer leeractiviteiten gaan ondernemen. Deze vraag staat centraal in dit rapport. Het feit dat diverse overheden, sociale partners en bedrijven in zowel binnen- als buitenland in de afgelopen jaren een heel scala aan vormen van individuele leerbudgetten met wisselend succes hebben toegepast, laat zien dat het beantwoorden van deze vraag geen sinecure is.

\section{Bestudeerde projecten en hun kenmerken}

Voor het beantwoorden van de vraag hoe een goed werkende opleidingscheque er uit zou moeten zien, is uitgebreid geput uit de opgedane ervaringen in een twintigtal eerdere projecten. Daarbij zijn zowel schriftelijke en digitale bronnen geraadpleegd, als ook gesprekken gevoerd met diverse experts uit het veld. Een deel van de geanalyseerde projecten is uitgevoerd door landelijke en regionale overheden in het Verenigd Koninkrijk, Duitsland, België, Oostenrijk, Zwitserland en de Provincie Noord-Brabant. Een ander deel van de projecten is opgezet door sociale partners in enkele Nederlandse bedrijfssectoren: de Metalektro, de Metaalbewerkingsbedrijven, de sector Aardappelen, groente en fruit en de Installatiebranche. Verder is ook gekeken naar projecten die in Nederland zijn opgezet door verschillende bedrijven: Philips, ING, KPN, Shell en Merck Sharp \& Dohme.

De individuele leerbudgetten binnen deze bedrijven hebben met elkaar gemeen dat alle werknemers die onder de bedrijfs-cao vallen er gebruik van mogen maken. Daarnaast verloopt de aanvraagprocedure van de meer recente leerbudgetprojecten doorgaans digitaal en zonder tussenkomst van de leidinggevende. De budgetten varieren in omvang tussen de $€ 227$ ( $f_{500}$ ) ) en $€$ I.000 per jaar en tussen de $€$ I.200 en $€ 2.500$ per drie jaar. De keuzevrijheid loopt sterk uiteen: van een paar specifieke door het bedrijf zelf geselecteerde leeractiviteiten in het E-miles programma van Philips tot het brede leeractiviteiten die gerelateerd zijn aan het werkzame leven en bijdragen aan het 
$C V^{\prime}$ van ING. Ook de deelnamepercentages lopen sterk uiteen (van I,3\% tot $45 \%$ ) en nemen (met uitzondering van het Persoonlijk Ontwikkelings Budget van Shell) toe naarmate de keuzevrijheid voor de deelnemers groter wordt.

Daarentegen wordt in de projecten die zijn opgezet door overheden en sociale partners, het leerbudget meestal aan bepaalde doelgroepen gegeven, zoals laagopgeleiden, 45-plussers, herintreders, werklozen, mensen werkzaam in het MKB of startende ondernemers. De budgetten met een looptijd van een jaar variëren van $€ 50$ tot $€$ I.OOO per jaar, terwijl meerjarige budgetten oplopen tot $€ 2.640$ te besteden in zes jaar. Opvallend is dat de leerbudgetten van Nederlandse overheden en sociale partners op bepaalde kenmerken verschillen van de budgetten van buitenlandse opleidingschequeprojecten. In Nederland zijn deze projecten bijvoorbeeld vaker door de sector opgezet, terwijl ook de keuzevrijheid groter is en de volledige kosten worden vergoed tot het maximale budget is bereikt. In andere landen neemt de regio of de deelstaat vaker het voortouw en moeten de leeractiviteiten gericht zijn op erkende beroepskwalificaties. Bovendien wordt er meestal slechts een bepaald percentage van de gemaakte kosten vergoed. Het ontbreken van goede evaluaties maakt het overigens vaak lastig om een oordeel te vellen over de behaalde resultaten van de projecten die de overheden en sociale partners hebben opgezet.

\section{Leerpunten}

De lessen die getrokken zijn uit de eerdere opleidingschequeprojecten, de gesprekken met experts en enkele theoretische inzichten zijn o.a. dat een opleidingscheque het beste werkt als:

- het individu de cheque als een waardevol bezit beschouwd;

- de cheque een goed op het bestedingsdoel afgestemde naam heeft;

- de cheque van voldoende omvang is, zodat een aanzienlijk deel van de leerkosten ermee betaald kunnen worden;

- de cheque slechts een beperkte tijd geldig is, omdat de ontvanger van de cheque daardoor een grotere prikkel heeft om na te denken over het bestedingsdoel en het daadwerkelijk gebruik van de cheque wordt gestimuleerd.

Ook is het belangrijk dat er een betrekkelijk grote keuzevrijheid is bij de besteding van de cheque, aangezien dat de kans vergroot dat iemand iets kan kiezen dat hem of haar het beste past. Deze keuzevrijheid moet zowel betrekking hebben op de inhoud (niet alleen cursussen en opleidingen, maar ook stages en loopbaanadviestrajecten) als ook op de keuze van de aanbieder (dichtbij werk/woonplaats, reguliere aanbieders en wijkcentra, etc.), Bovendien moet de administratieve procedure rond het inwisselen van de cheque zo eenvoudig mogelijk zijn.

Idealiter wordt de cheque opgenomen als een integraal onderdeel van een Persoonlijk Ontwikkelingsplan (POP) of een ander ontwikkeltraject. Ook is het belangrijk dat een opleidingscheque breed en herhaaldelijk onder de aandacht wordt gebracht via 
kanalen die zijn afgestemd op de doelgroep. Deze begeleiding dient laagdrempelig en vrijwillig te zijn, om niet als een barrière gezien te worden. Werkgevers, O\&O-fondsen, collega's en andere peergroups kunnen hierbij een belangrijke rol spelen, mits zij goed geïnformeerd zijn over én een positieve attitude hebben ten opzichte van de cheque. Wanneer er een eigen bijdrage van de werknemer gevraagd wordt, lijkt eigen tijd een betere optie dan eigen geld, al hoewel ook de tijdsinvestering als een leerbarrière ervaren kan worden, zeker door laagopgeleiden.

\section{Ontwikkelingscheque}

Het hier voorgestelde model voor de opzet van de Ontwikkelingscheque gaat uit van twee stapelbare cheques, elk ter waarde van $€ 500$, die jaarlijks aan werknemers worden gegeven. De ene cheque wordt gefinancierd door de overheid en de andere door het O\&O-fonds of de werkgever. Beide cheques zijn maximaal drie jaar geldig. Op deze manier kan de ontvanger cheques stapelen voor duurdere leeractiviteiten, maar voorkomt de termijn van drie jaar afstel door uitstel. Ook zorgt de gedeelde financiering voor gezamenlijke betrokkenheid van overheid en sociale partners. De cheques worden uitgegeven door een bestaande overheidsinstantie, bijvoorbeeld het Agentschap SZW of DUO. Hierdoor worden de uitvoeringskosten beperkt.

De Ontwikkelingscheque mag worden besteed aan niet-functiegerichte leeractiviteiten en andere activiteiten gericht op de loopbaanontwikkeling. De cheque kan alleen worden besteed bij gecertificeerde aanbieders van leeractiviteiten e.d. De werknemer wisselt de cheque in door deze op te sturen met een (digitaal) formulier waarop de werknemer de activiteit, de plaats, periode, kosten en de motivatie vermeldt en waarop de handtekening van de werkgever, het O\&O-fonds óf het servicepunt Leren en Werken staat. Door deze werkwijze:

- blijft de werkgever verantwoordelijk voor de functiegerichte leeractiviteiten;

- moet de werknemer zijn leerwens concreet maken;

- kan informatie verzameld worden die vereist is voor een goede monitoring en evaluatie;

- wordt fraude bestreden;

- wordt de dialoog tussen werknemer en de werkgever, of een andere betrokken partij gestimuleerd.

De werknemer kan bij de werkgever ook terecht voor begeleiding bij het keuzeproces, al zal het MKB hierbij ondersteund moeten worden door O\&O-fondsen, brancheorganisaties, vakbonden of de servicepunten Leren en Werken. Uitgangspunt is dat de keuze voor de begeleiding bij de werknemer ligt en dat deze begeleiding eenvoudig toegankelijk is. 


\section{Specifiek model voor werknemers zonder startkwalificatie}

Met name bij de werkenden zonder startkwalificatie voor de arbeidsmarkt is de deelname aan het leven lang leren erg laag. Voor deze laagopgeleiden zou het model voor de Ontwikkelingscheque op een aantal punten moeten worden aangepast. Daarom zou het goed zijn als laagopgeleiden de Ontwikkelingscheques ook aan functiegerichte leeractiviteiten mogen besteden. De Ontwikkelingscheque moet bij laagopgeleide werknemers ook goed onder de aandacht worden gebracht door een persoonlijke benadering met veel mondelinge communicatie, bij voorkeur met iemand waarmee de laagopgeleide werknemer een vertrouwensband heeft, bijvoorbeeld seniorcollega's, OR- of vakbondsleden. Ook moet er extra aandacht worden besteed aan de ondersteuning bij het inwisselen van de cheque.

Op die manier wordt de drempel naar een leven lang leren voor laagopgeleiden verder verlaagd. Dát deze doelgroep weer gaat leren is immers vaak in eerste instantie nog belangrijker dan wát er inhoudelijk precies geleerd wordt. Verder zal de communicatie en begeleiding voor deze groep zoveel mogelijk via persoonlijk contact moeten plaatsvinden. Om na verloop van tijd de activiteiten naar een hoger c.q. meer inhoudelijk plan te tillen, moeten deze gemonitord worden zodat de begeleider informatie heeft om het ontwikkelproces goed te begeleiden.

\section{De eerste stap}

Een inschatting van de benodigde middelen, zowel van de kant van de overheid als van de kant van de O\&O-fondsen of werkgevers, leidt al snel tot de conclusie dat de invoering van een Ontwikkelingscheque voor alle werkenden financieel geen haalbare kaart is. Ook de invoering van de voorgestelde Ontwikkelingscheque voor alle werkenden zonder startkwalificatie (iets minder dan 2 miljoen) is al een erg kostbare zaak. Het zou de overheid en de O\&O-fondsen of werkgevers bij een deelnamepercentage van 50\% elk namelijk al $€ 495$ miljoen per jaar kosten.

Een verdere inperking van de doelgroep lijkt daarom noodzakelijk om een eerste stap te kunnen zetten. Een mogelijk uitgangspunt daarbij is dat de urgentie om de deelname aan een leven lang leren te stimuleren het grootst is voor laagopgeleide werknemers in sectoren waar de werkgelegenheid krimpt en de komende jaren nog verder zal teruglopen. Dit is bijvoorbeeld het geval in de sectoren hout- en bouwmaterialen, landbouw en visserij, metaalproducten en kunststofverwerking. In deze 'krimp'sectoren zijn 300.000 laagopgeleiden werkzaam. Dit betekent dat de kosten van de Ontwikkelingscheque voor deze beperkte doelgroep bij een deelnamepercentage van $50 \%$ ongeveer $€ 75$ miljoen bedragen voor de overheid en eenzelfde bedrag voor de O\&O-fondsen of werkgevers. Daarbij is overigens nog geen rekening gehouden met de operationele kosten voor de uitgifte en het beheer van de Ontwikkelingscheque en de kosten van de begeleiding van de laagopgeleide werknemers. Deze begeleiding is zoals gezegd van cruciaal belang om de Ontwikkelingscheque te laten slagen. 


\section{Inleiding}

\subsection{Achtergrond onderzoek}

De Denktank Leren en Werken vindt het van groot belang dat de Nederlandse burgers en het bedrijfsleven een leven lang leren serieus gaan nemen. Zij voert hiervoor een aantal redenen aan. Zo is het tempo van de economische dynamiek dusdanig hoog dat er in veel functies steeds meer en nieuwe competenties nodig zijn om deze adequaat te kunnen uitoefenen. Ook neemt de beroepsbevolking in de komende 20 jaar af, waardoor minder mensen meer zullen moeten produceren waarvoor een hoger kwalificatieniveau vereist is. Bovendien verliest de vergrijzende beroepsbevolking haar competenties als zij die niet traint door het 'use it or loose it'-principe. En tot slot wijst de Denktank Leren en Werken op het grote aantal Nederlanders (I,I miljoen mensen oftewel I0,5\% van de bevolking van I6-64 jaar in 2008) dat volgens de definitie van het OECD laaggeletterd is. ${ }^{\mathrm{I}}$

Diverse onderzoeken geven echter aan dat slechts een beperkt deel van de Nederlandse beroepsbevolking aanvullende scholing volgt. Volgens de Labour Force Survey (LFS) volgde in $2009 \mathrm{I} 7 \%$ van de $25 \mathrm{t} / \mathrm{m}$ 64-jarigen een cursus of opleiding. ${ }^{2}$ In het voorjaar van 2008 had, volgens de Adult Education Survey (AES) van het CBS, 28\% ${ }^{3}$ van alle $25 \mathrm{t} / \mathrm{m}$ 64-jarigen deelgenomen aan enige vorm van aanvullende scholing (bestaande uit cursussen, trainingen, privélessen, afstandsonderwijs, seminars/workshops e.d). Uit de AES blijkt dat gebrek aan geld en tijd belangrijke hindernissen zijn voor werkenden die willen leren.

In haar advies Tijd voor ontwikkeling heeft de Denktank Leren en Werken voorgesteld om het leven lang leren in Nederland een impuls te geven door het invoeren van

I. Denktank Leren en Werken (2009), Tijd voor ontwikkeling: Advies van de Denktank Leren en Werken over het stimuleren van een leven lang leren in Nederland, Den Haag: Ministeries van Onderwijs, Cultuur en Wetenschap en Sociale Zaken en Werkgelegenheid.

2. Het betreft allerlei soorten cursussen en opleidingen waaraan de respondent deelnam in de vier weken voorafgaand aan het enquêtemoment. De gevolgde cursus of opleiding hoeft niet relevant te zijn voor iemands huidige of toekomstige baan. Bron: Eurostat.

3. Het verschil tussen de percentages uit de LFS en de AES kan worden verklaard door de verschillende definities van scholing en door het verschil in de periode waarin de scholing plaatsvond. De LFS kijkt naar scholing gevolgd in de laatste vier weken, terwijl het AES een jaar terugkijkt. 
een opleidingscheque, die het voor individuen mogelijk maakt om het eigen leren te financieren. Door middel van deze opleidingscheque wil de Denktank het voor volwassenen aantrekkelijker maken om zichzelf te blijven ontwikkelen. Ook wil de Denktank met de cheque een bijdrage leveren aan het bevorderen van een leercultuur en individuen bewust maken van het rendement dat het volgen van aanvullende scholing voor hun loopbaanontwikkeling kan hebben. De invoering van de opleidingscheque zou volgens de Denktank gefaseerd moeten plaatsvinden: eerst zou de opleidingscheque beschikbaar moeten worden gesteld aan werknemers van 50 jaar en ouder, werknemers zonder startkwalificatie ${ }^{4}$ en werknemers met een baan van maximaal 24 uur per week. Op de lange termijn wil de Denktank dat alle volwassenen over een opleidingscheque kunnen beschikken.

Een opleidingscheque is een vorm van een individueel leerbudget waarbij een bedrag rechtstreeks ter beschikking wordt gesteld aan het individu om (deels) naar eigen inzicht te besteden aan (bepaalde) leeractiviteiten. Enkele onderzoeken hebben aangetoond dat dergelijke individuele leerbudgetten individuen inderdaad kunnen stimuleren om leeractiviteiten te ontplooien die men anders achterwege zou laten. ${ }^{6}$ Bovengenoemde studies naar de effectiviteit van een individueel leerbudget hebben laten zien dat een opleidingscheque effectief kan zijn, mits het budget niet te klein is en het instrument op een adequate manier wordt uitgevoerd. Het is dan ook de uitvoering van een opleidingscheque die in dit onderzoek centraal staat.

\subsection{Onderzoeksopzet}

In deze studie zal een concreet voorstel voor een dergelijke opleidingscheque c.q. Ontwikkelingscheque ${ }^{7}$ worden uitgewerkt. Daarbij hebben we gewerkt volgens een 'trechtermodel'. Eerst wordt er een overzicht gegeven van eerdere projecten met opleidingscheques, vouchers, e.d. die individuele werkenden in staat stellen om op eigen initiatief een bepaalde training of cursus te gaan volgen. Daarbij is zowel gekeken naar projecten in Nederland als naar eerdere projecten in andere landen. Op basis van dit overzicht is vervolgens een inventarisatie gemaakt van twintig projecten van individuele leerbudgetten c.q. opleidingscheques. Op basis van deze voorbeelden hebben we een overzicht van leerpunten opgesteld in combinatie met suggesties vanuit de economische theorie. In de tweede onderzoeksstap hebben we, op basis van deze leer-

4. Iemand mét een startkwalificatie heeft een HAVO- of VWO-diploma of een diploma op minimaal MBO niveau 2.

5. Zie voetnoot I.

6. Messer, D., \& S.C. Wolter (2009), Money matters: Evidence from a large-scale randomized fiels experiment with vouchers for adult training, CESifo Working Paper 2548, Munich.

Groot, W. en H. Maassen van den Brink (2009), Werkt het scholingsbudget?: In opdracht van de Denktank Leren en Werken, Amsterdam: TIER;

Dagevos, J. e.a. (2009), Een duwtje in de rug: Evaluatie van de provinciale leerbonnen, Tilburg: TELOS.

7. Op basis van redenen die worden toegelicht in hoofdstuk 4 (paragraaf 4.I.I), is gekozen voor de naam Ontwikkelingscheque in plaats van opleidingscheque. 
punten, een conceptmodel voor een Ontwikkelingscheque opgesteld dat vervolgens uitvoerig is besproken met diverse partijen uit het veld. Op basis van deze feedback is het model verder ontwikkeld.

\subsection{Leeswijzer}

In hoofdstuk 2 wordt een aantal theoretische principes besproken die aanknopingspunten bieden voor de uitvoering van een Ontwikkelingscheque. Daarnaast zal het overgrote deel van dit hoofdstuk een beschrijving geven van de diverse praktijkvoorbeelden van individuele leerbudgetten. In hoofdstuk 3 worden de leerpunten voor de Ontwikkelingscheque gepresenteerd op basis van de theorie en de praktijkvoorbeelden en gesprekken met experts. In hoofdstuk 4 staat het uitvoeringsmodel van de Ontwikkelingscheque centraal, dat op basis van de leerpunten uit hoofdstuk 3 en de feedback van de geraadpleegde experts tot stand is gekomen. 



\section{Het individuele leerbudget: leren van het verleden}

Het individuele leerbudget is een instrument waar al meerdere malen en in diverse landen mee geëxperimenteerd is door het uitvoeren van pilotprojecten. Deze pilotprojecten leveren potentieel waardevolle inzichten op voor het invoeren van de beoogde Ontwikkelingscheque. In dit hoofdstuk wordt daarom een beeld geschetst van de ontwikkelingen in de laatste tien jaar waarbij wordt ingezoomd op een twintigtal pilotprojecten in binnen-en buitenland. Het hoofdstuk begint met een aantal relevante inzichten uit de economische theorie (paragraaf 2.I) gevolgd door beschrijvingen van een vijftal pilotprojecten van Nederlandse bedrijven (paragraaf 2.2). Tot slot worden in paragraaf 2.3 vijftien projecten belicht, die door overheden of sociale partners in binnen-en buitenland zijn uitgevoerd.

\subsection{Endowment en labeling}

\section{Endowment}

Onderzoek laat zien dat consumenten zich lang niet altijd rationeel gedragen. Kahneman en Tversky (1979) hebben consumenten diverse keuzes voorgelegd waarvan de theorie voorspelde dat zij geen voorkeur voor een bepaalde keuze zouden hebben. ${ }^{8}$ Deze voorspellingen bleken niet te kloppen zoals onderstaande voorbeelden laten zien:

\section{Situatie I}

Je ontvangt $€$ I.OOO. Daarnaast heb je de keuze tussen a) 50\% kans op $€$ I.000 en $50 \%$ kans op $€$ o of b) I00\% kans op $€ 500$. De verwachte waarde van beide keuzes is hetzelfde, namelijk $€ \mathrm{I} .500$ ( $€ \mathrm{I} .000+0,5 \mathrm{x} € \mathrm{I} .000=€ \mathrm{I} .500$ en $€ \mathrm{I} .000+\mathrm{I}$ x $€ 500$ $=€ \mathrm{I} .500)$. Echter, $84 \%$ van de consumenten kiest voor de 'zekere' $€$ I.500 en slechts I6\% voor de $50 \%$ kans op $€ 2.000$ en $50 \%$ kans op $€$ I.000.

\section{Situatie 2}

Je ontvangt $€$ 2.000. Daarnaast heb je de keuze uit a) 50\% kans om $€$ I.000 te verliezen en $50 \%$ kans op $€$ o verlies en b) een zeker verlies van $€ 500$. Ook hier is de verwachte

8. Kahneman, Daniel and Amos Tversky (1979), Prospect Theory: An Analysis of Decision under Risk, Econometrica, Vol. 47, No. 2, pp. 263-292. 
waarde van de einduitkomsten van de keuzes gelijk (€ I.500). Hier kiest echter $69 \%$ van de consumenten voor de eerste optie en slechts $31 \%$ voor de zekere uitkomst van $€ \mathrm{I} .500$.

Op basis van deze en andere situaties hebben Kahneman en Tversky een aantal conclusies getrokken. Ten eerste behandelen consumenten winst en verlies geheel verschillend. Als het om winst gaat, vertonen consumenten risicoaversie (een meerderheid verkiest een lagere zekere winst boven de onzekere hogere winst), terwijl ze bij verlies juist risiconemend zijn (een meerderheid verkiest het onzekere hogere verlies boven het zekere lagere verlies). Verliezen wat je als je bezit beschouwt, doet blijkbaar meer pijn dan de vreugde van een mogelijke winst. Ten tweede hechten consumenten meer waarde aan zekere boven onzekere uitkomsten en ten derde blijkt dat het nogal wat uitmaakt hoe je een situatie presenteert. De verwachte waardes in situatie I zijn gelijk aan die van situatie 2 (€ I.50O), echter in situatie I valt er bovenop de $€$ I.OOO geld te winnen en in situatie 2 heb je $€ 2.000$ en kun je daar een deel van verliezen. Dit leidt tot andere keuzes. Het feit dat mensen anders kiezen als ze iets kunnen verliezen dan als ze iets kunnen winnen verklaren Kahneman en Tversky door het 'endowment effect'. Dit effect treedt op omdat individuen een hogere waarde toekennen aan objecten die ze in bezit hebben, dan aan exact dezelfde mogelijkheden die ze niet zelf in bezit hebben. Oftewel verliezen wat je hebt, heeft meer impact dan mogelijk iets kunnen bezitten dat je nu niet bezit.

\section{Labeling}

Wanneer een subsidie wordt uitgekeerd met een bepaald doel, dan krijgt deze subsidie doorgaans een naam mee die verwijst naar de beoogde bestemming. De keuze van die naam (of etiket) lijkt van ondergeschikt belang. Onderzoek van Kooreman geeft echter aan dat dit etiket ("label") effect kan hebben op de besteding van het geld. ${ }^{9}$ Kooreman heeft het uitgavenpatroon onderzocht van Nederlandse huishoudens die kinderbijslag ontvangen. Deze bijslag draagt dan wel de naam "kinderbijslag", maar gezinnen zijn volledig vrij om deze middelen naar eigen inzicht te besteden, aangezien er geen regels m.b.t. de besteding van de kinderbijslag zijn. Uit het onderzoek van Kooreman blijkt dat huishoudens de kinderkleding veel vaker van de kinderbijslag betalen dan van elke andere inkomensbron. Het label of etiket "kinderbijslag" dat aan het bedrag hangt, lijkt er dus voor te zorgen dat het geld inderdaad aan de kinderen wordt besteed. Dit verschijnsel noemt men het 'labeling effect'.

9. Peter Kooreman (2000), The Labeling Effect of a Child Benefit System, The American Economic Review, Vol. 90, No. 3, pp. 571-583. 


\subsection{Pilotprojecten van bedrijven}

Zowel binnen als buiten Nederland is er in de afgelopen jaren veel ervaring opgedaan met verschillende vormen van individuele financiering van leren. Binnen Nederland heeft de projectdirectie Leren en Werken bijvoorbeeld diverse pilotprojecten opgezet of mede gefinancierd. Daarnaast hebben bedrijven of de sociale partners in bepaalde sectoren en ook enkele provincies en gemeenten gewerkt aan experimenten met vraaggestuurde financiering van trainingen. Ook in andere Europese landen is er geëxperimenteerd met zogenaamde Individual Learning Accounts (ILAs), zo bleek op een CEDEFOP seminar eind januari 2008. ${ }^{\text {I0 }}$ In tabel $\mathrm{B}_{1}$ en $\mathrm{B}_{2}$ in de bijlage wordt een overzicht gegeven van allerlei vormen van individuele financiering van leren uit binnen- en buitenland. Dit overzicht heeft niet de intentie compleet te zijn, maar heeft als doel een goed beeld te geven van de variatie in vormen, doelstellingen, betrokken partijen, e.d. van de diverse financieringsvormen.

Uit de voorbeelden in tabel $\mathrm{B}_{1}$ en $\mathrm{B}_{2}$ in de bijlage zijn 20 projecten geselecteerd: vijf bedrijfspilotprojecten en vijftien pilotprojecten opgezet door overheden of sociale partners. De selectie van deze projecten heeft plaatsgevonden op basis van één of meerdere van de volgende criteria:

- Het project is gericht op één of meerdere van de volgende groepen:

- (werkende) personen zonder startkwalificatie

(in dit rapport ook aangeduid met de term laagopgeleiden);

- werkenden van 50 jaar en ouder;

- werkenden met een parttime baan.

- Er is voldoende informatie over het project beschikbaar om er een voldoende compleet beeld van te kunnen geven (werking, resultaten, e.d.). Lang niet alle voorbeelden bleken even goed gedocumenteerd of geëvalueerd te zijn. Met name bij ILAs die al langer geleden plaatsvonden, is het zeer moeilijk gebleken om geschikte informatie te achterhalen.

- Het project bevat bruikbare lessen door het succes van de vorm (do's) of juist door het tegenvallende resultaat (don'ts).

De vijf pilotprojecten opgezet door bedrijven worden in deze paragraaf eerst in tabel 2.I kort schematische weergegeven en daarna verder uitgediept door een casebeschrijving. De vijftien pilotprojecten uitgevoerd op initiatief van overheden of sociale partners worden op vergelijkbare wijze in paragraaf 2.3 gepresenteerd. In de beschrijving van de onderstaande pilotprojecten worden de relevante aspecten van het project zoveel mogelijk in een vaste volgorde besproken. Dit om een vergelijking tussen de verschillende projecten mogelijk te maken en om bepaalde aspecten snel terug te

IO. Seminar on individual learning accounts: An incentive for financing continuing vocational education and training georganiseerd door CEDEFOP (European Centre for the Development of Vocational Tranining) op 3I januari 2008 te Thessaloniki, Griekenland. 
kunnen vinden. Door het ontbreken van sommige gegevens zal echter niet elk aspect in elke casebeschrijving terug te vinden zijn of worden soms andere termen gebruikt. De aspecten zijn als volgt verdeeld in een vijftal groepen:

- Beschrijving: hoogte van het bedrag, frequentie, cumulatie of niet, spaarelement, eigen bijdrage.

- Uitvoering en beheer: centrale of decentrale uitgifte, voor wie bestemd, toegestane cursussen, wijze van aanvragen, toetsing en controle, beheer door wie (decentraal/centraal).

- Communicatie en begeleiding: introductie, begeleiding (voor wie, door wie).

- Financiering: wie (overheid, sociale partners, bedrijf, individu) levert welke bijdrage, kosten.

- Resultaten

\subsubsection{Het individueel inzetbaarheidbudget van KPN ${ }^{11}$}

\section{Beschrijuing}

Werknemers van KPN hebben sinds 2008 per jaar $€$ I.00o te besteden. Cumulatie is mogelijk, want het budget dat in het ene jaar niet besteed wordt, mag in het jaar erna gebruikt worden.

\section{Uitvoering en beheer}

Alle werknemers die onder de KPN CAO vallen kunnen hun budget besteden aan o.a. opleidingen en online assessments. De besteding was bij de start van het budget volledig vrij, mits de leidinggevende akkoord ging met de keuze. Als gevolg van fraude heeft KPN de keuze van de werknemers beperkt door een digitaal opleidingspakket samen te stellen bestaande uit I.400 opleidingen inclusief een blacklist. Vanaf 2010 wordt echter het keuzepakket van het inzetbaarheidbudget weer uitgebreid met instrumenten gericht op gezondheid (leefstijl en preventie) waaronder een gezondheidscheck. De werknemer zet het individueel inzetbaarheidbudget in via het internetportal 'Mijn Kompas'. Via dit portal kiest de werknemer zijn opleiding, assessment of ander instrument en kan de procedure zonder verdere tussenkomst van een leidinggevende worden afgerond. KPN streeft ernaar om 'Mijn Kompas' in 2010 I00\% zelfsturend (geautomatiseerd) te laten werken zodat de manager volledig vrijgesteld wordt van eventuele goedkeuringen en de medewerkers nog eenvoudiger hun aanvraag kunnen voltooien.

II. Bronnen:

http://www.ncsi.nl/nl/kennis/kennisbank/kpn-mijn-kompas--instrument-voor-socialeinnovatie/451?q=mjin kompas sociale innovatie (29 maart 20II);

KPN Duurzaamheidsverslagen van 2008 en 2009 ; KPN CAO 20I0, Onderhandelaarsakkoord 28 april 2010. 


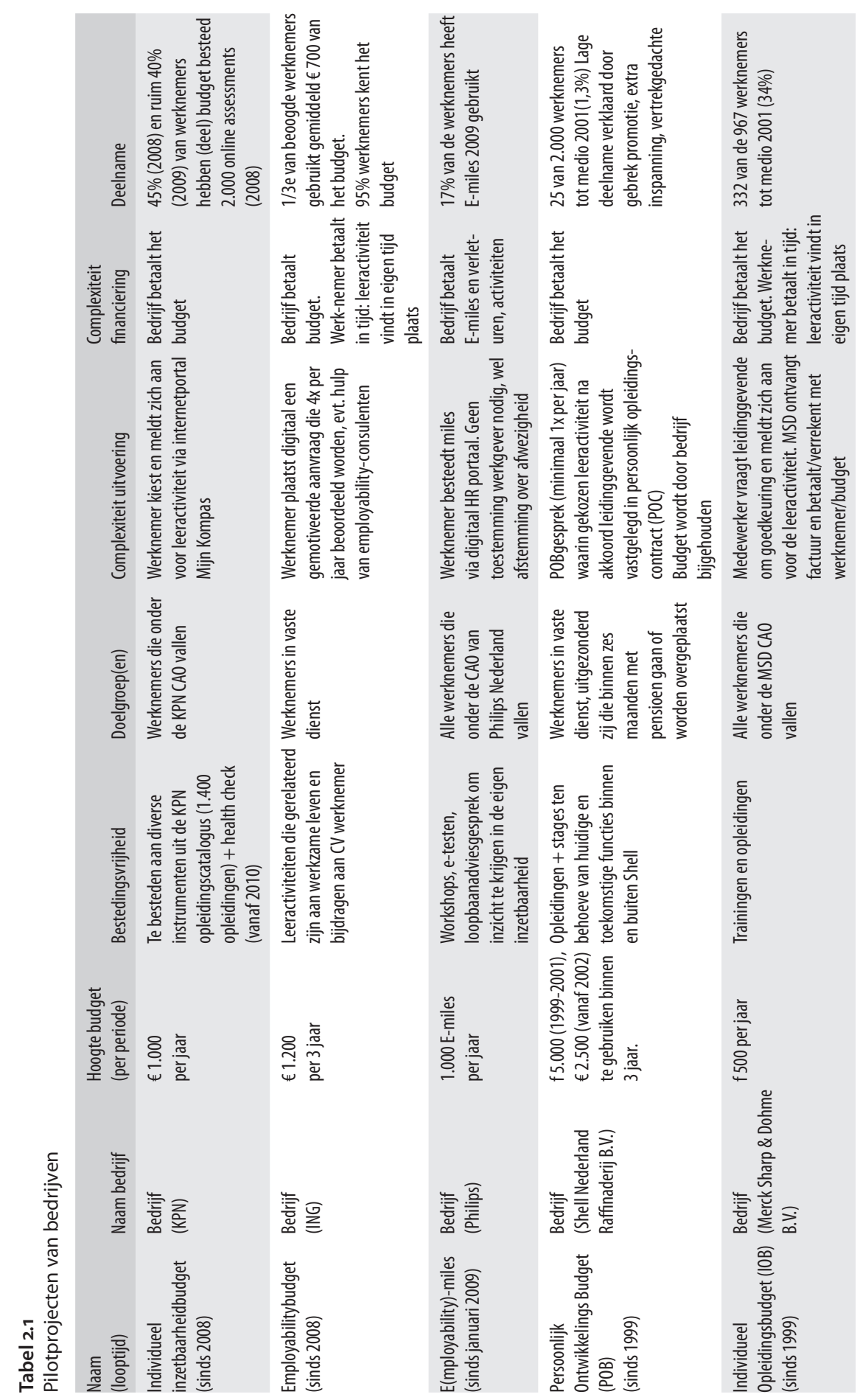


Communicatie en begeleiding

Internetportal Mijn Kompas, HR-afdeling en leidinggevende.

\section{Financiering}

Het budget wordt ter beschikking gesteld door KPN.

\section{Resultaat}

In 2008 heeft $45 \%$ en in 2009 ruim $40 \%$ van de werknemers hun budget (deels) besteed. Daarnaast hebben ruim 2.000 mensen de korte online assessment gedaan.

\subsubsection{Het employabilitybudget van ING ${ }^{12}$}

\section{Beschrijving}

Sinds januari 2008 hebben ING-werknemers de beschikking over een employabilitybudget van $€ \mathrm{I} .200$ dat moet worden besteed binnen een periode van drie kalenderjaren. Cumulatie van meerdere budgetten is dus niet mogelijk.

\section{Uitvoering en beheer}

Iedere werknemer van ING met een dienstverband voor onbepaalde tijd ontvangt dit employabilitybudget dat vrij mag worden besteed zo lang de activiteit (opleiding, cursus, coachingstraject, etc.) bijdraagt aan het (toekomstige) werkzame leven of iets toevoegt aan het $\mathrm{CV}$ van de werknemer. Het employabilitybudget staat los van het reguliere opleidingsbudget dat bestemd is voor opleidingen gericht op de eigen functie of de geplande volgende functie en staat ook los van een eventueel Sociaal Plan. De werknemer vult digitaal een formulier in waarin hij aangeeft wat hij wil gaan doen en wanneer, de kosten van het employabilitydoel en een korte motivering. Na verzending wordt dit formulier door twee personen van het toekenningsteam onafhankelijk van elkaar beoordeeld. Na goedkeuring neemt de werknemer contact op met de aanbieder van de activiteit voor het regelen van deelname en afhandeling van de factuur. De werknemer dient de factuur in bij ING en betaalt de aanbieder.

\section{Communicatie en begeleiding}

ING heeft employability-consulenten aangesteld die werknemers en leidinggevenden ondersteunen en stimuleren. Bijvoorbeeld door als vraagbaak op te treden en mensen de weg te wijzen.

\section{Financiering}

Het budget wordt ter beschikking gesteld door ING, dat daar $€$ Io miljoen per jaar voor heeft gereserveerd. De werknemer investeert zijn tijd in het budget doordat de leeractiviteiten in eigen tijd plaatsvinden.

I2. Bronnen: ING-CAO 2008-20IO, p. 32; Dhr. W. Daalder (voormalig programmamanager Employability), ING. 


\section{Resultaat}

Ongeveer een derde van de werknemers in vaste dienst heeft gebruik gemaakt van hun employabilitybudget. Gemiddeld wordt $€ 700$ van het budget besteed. Er zijn geen verschillen tussen de 'gebruikers' en de 'niet-gebruikers' van het budget, behalve dat werknemers die langer dan 25 jaar in dienst zijn van ING relatief minder gebruik maken van het budget. Er is veel gebruik gemaakt van de employabilityconsulenten, concrete cijfers hierover ontbreken echter. De bekendheid van het employabilitybudget is groot: 95\% van de werknemers kent het. Het employabilitybudget wordt in ieder geval tot en met 20 II voortgezet parallel aan de looptijd van de huidige CAO.

\subsubsection{De E(mployability)-miles van Philips ${ }^{13}$}

\section{Beschrijving}

Werknemers van Philips Nederland ontvangen sinds I januari 2009 jaarlijks I.000 E-miles die zij gedurende dat kalenderjaar kunnen besteden. Niet bestede miles vervallen na 3 I december van dat kalenderjaar en er is dan ook geen cumulatie mogelijk.

\section{Uitvoering en beheer}

Alle werknemers vallend onder de CAO van Philips Nederland kunnen hun E-miles besteden aan activiteiten als loopbaangesprekken (zowel individueel als in groepsverband) en diverse testen (via de PC) om zicht te krijgen op de eigen loopbaan, persoonlijkheid, vaardigheden, interesses en werkstijlen. Een workshop in groepsverband kost bijvoorbeeld 300 E-miles, de E-check (online vragenlijsten, een rapportage inclusief bespreking en adviesgesprek) kost I.00o E-miles. Het doel van dit programma is werknemers inzicht te laten krijgen in de eigen mate van inzetbaarheid ("wie ben ik, wat wil ik, wat kan ik?”). De werknemer besteedt de E-miles digitaal via het HR-portaal en doet dit zonder inmenging van de leidinggevende. De gekozen activiteit wordt uitgevoerd onder werktijd en de afwezigheid hiervoor moet wel tijdig met de leidinggevende worden afgestemd.

\section{Communicatie en begeleiding}

Via het HR-portaal, HR-afdeling en leidinggevende. Ook zijn er groepsbijeenkomsten belegd waarin de E-miles en de bestedingsmogelijkheden nog eens zijn uitgelegd.

\section{Financiering}

De E-miles worden door Philips betaald.

I3. Bronnen: CAO Philips 2008-2009; Gerards, R. en A. de Grip (20IO), Managementrapportage E-miles, Oktober 20Io, Maastricht (interne publicatie); dhr. R. Gerards (onderzoekt E-miles in promotieonderzoek), Universiteit Maastricht. http://www.philips.nl/about/carriere/werken_bij_philips/jouw_ mogelijkheden/coaching feedback/index.page (29 maart 20II). 


\section{Resultaat}

De E-miles ontvangen in 2009 blijken begin 2010 door $17 \%$ van de ontvangers te zijn gebruikt. Er was een duidelijke piek waar te nemen in de laatste weken van het jaar toen de miles dreigden te verlopen (ondanks het feit dat mensen wisten dat ze in 2010 weer nieuw miles zouden krijgen). Frequent en tijdig werknemers eraan herinneren dat de miles nog besteed moeten worden, bleek geen overbodig luxe. Redenen om de miles niet te gebruiken zijn zeer divers, maar geen tijd (22\%), geen nuttige producten in het aanbod (I4\%) en onbekendheid met de E-miles (I2\%) worden het vaakst genoemd. Het management bleek niet altijd even goed op de hoogte te zijn van de regeling om het gebruik ervan te kunnen stimuleren. De gebruikers van de E-miles zijn ten opzichte van de niet-gebruikers vaker hoogopgeleid, jonger en vrouw.

\subsubsection{Persoonlijk Ontwikkelings Budget (POB) van Shell ${ }^{14}$}

\section{Beschrijving}

Sinds 1999 kunnen werknemers van Shell Nederland Raffinaderij B.V. beschikken over een Persoonlijk Ontwikkelingsbudget (POB). Bij aanvang in 1999 bedroeg het POB $f 5.000$ te besteden binnen drie jaar, vanaf 2002 is dit gewijzigd in $€ 2.500$ per drie jaar. De verschillende budgetten zijn dus niet cumuleerbaar.

\section{Uitvoering en beheer}

Werknemers die in vaste dienst zijn van Shell Nederland Raffinaderij B.V. kunnen, ongeacht de omvang van hun dienstverband, gebruik maken van het POB. Werknemers met een contract korter dan drie jaar, werknemers die binnen twaalf maanden met pensioen gaan of werknemers die binnen zes maanden worden overgeplaatst naar een andere Shell-maatschappij kunnen geen gebruik maken van het POB. Het POB kan worden ingezet voor alle opleidingen die de kennis en kunde van de werknemer in zijn huidige of toekomstige functie vergroten of die de werknemer meer mogelijkheden bieden op de arbeidsmarkt buiten Shell. Ook kan het POB worden besteed aan een stage om inzicht te krijgen in een ander vakgebied of functie. Daarnaast is er nog extra financiering mogelijk voor deskundig loopbaan-/ opleidingsadvies bovenop het POB tot maximaal $\mathrm{f}$ I.500 per drie jaar. Het POB dient de employability van de werknemers te vergroten. Ten minste eenmaal per jaar bespreekt de werknemer het benutten van zijn POB met de directe leidinggevende. De in dat gesprek gemaakte afspraken (gekozen opleiding of stage) worden vastgelegd in een persoonlijk opleidingscontract (POC) dat door beiden wordt ondertekend. Toestemming van de leidinggevende voor de gekozen opleiding of stage is dus vereist. De werknemer is vrij in de keuze voor de opleidingsinstelling, Shell schrijft de werknemer in. Het budget wordt centraal geadministreerd door Shell.

I4. Bron: De Korte, A.W. e.a. (200I), Eindrapport verkenning van de POR: een onderzoek naar de mogelijkheden tot invoering van een persoonlijke ontwikkelingsrekening in Nederland, Utrecht: Berenschot en PriceWaterhouseCoopers. 


\section{Communicatie en begeleiding}

Door leidinggevende in een jaarlijks gesprek.

\section{Financiering}

Het POB is toegevoegd aan de bestaande zelfstudieregeling van Shell en geldt als complementaire regeling voor extra opties (in geld of tijd) waarin de zelfstudieregeling niet voorziet. Shell betaalt het POB volledig.

\section{Resultaat}

In de periode 1999 - medio 200 I hebben ongeveer 25 werknemers gebruikgemaakt van het POB op een totaal personeelsbestand van 2.000 werknemers (I,3\%). Deze geringe deelname wordt verklaard door de extra inspanning die gevergd wordt van mensen om echt iets nieuws te gaan leren. Ook zijn veel medewerkers bang dat men denkt dat zij Shell willen verlaten als zij een opleiding volgen voor een andersoortige functie. Door een betere promotie van het $\mathrm{POB}$ en een verhoging van het budget probeert Shell deelname aan de regeling te stimuleren.

\subsubsection{Individueel Opleidingsbudget (IOB) van MSD $^{15}$}

\section{Beschrijuing}

Sinds 1999 beschikken werknemers van Merck Sharp \& Dohme (MSD) B.V. over een Individueel Opleidingsbudget (IOB) van $\mathrm{f} 500$ per jaar dat is bedoeld om het leren door werknemers te stimuleren. In 1999 is het IOB als experiment begonnen, maar inmiddels is het een regulier instrument dat onderdeel is van de Opleidingskostenregeling.

\section{Uitvoering en beheer}

De werknemers die onder de CAO van Merck Sharp \& Dohme (MSD) B.V. vallen ontvangen allen een IOB dat zij uitsluitend mogen besteden aan trainingen en opleidingen. De werknemer kiest een opleiding of training uit en laat deze door de leidinggevende goedkeuren. Vervolgens meldt de werknemer zich aan bij het opleidingsinstituut dat hij heeft gekozen uit een gelimiteerd aanbod en volgt de opleiding in eigen tijd. De rekening wordt naar MSD gestuurd die deze verrekent met het IOB en een eventueel restbedrag met de werknemer. Het budget wordt dus centraal geadministreerd door MSD.

\section{Communicatie en begeleiding}

Bij de invoering van het budget in 1999 heeft men door middel van een interne PR-actie het IOB onder de aandacht van werknemers gebracht.

I5. Bron: De Korte, A.W. e.a. (200I), Eindrapport verkenning van de POR: een onderzoek naar de mogelijkheden tot invoering van een persoonlijke ontwikkelingsrekening in Nederland, Utrecht: Berenschot en PriceWaterhouseCoopers. 


\section{Financiering}

Het IOB wordt volledig door MSD gefinancierd.

\section{Resultaat}

Sinds de invoering van het IOB heeft $34 \%$ van de werknemers er gebruik van gemaakt (tot medio 200I). De cursusonderwerpen van de gevolgde trainingen en opleidingen zijn zeer divers: computer (I7\%), talen (I4\%) en personal development (II\%), maar ook auto/boot (I4\%). Daarnaast komen onderwerpen als verzorging, financiën en muziek voor.

\subsubsection{Samenvatting}

De besproken voorbeelden van de individuele leerbudgetten die binnen bedrijven zijn gebruikt, hebben met elkaar gemeen dat werknemers er gebruik van mogen maken mits zij onder de bedrijfs-cao vallen. Bij ING en Shell is het budget beperkt tot de werknemers met een vast dienstverband. Daarnaast verloopt de aanvraagprocedure van de meer recente leerbudget projecten doorgaans digitaal en zonder tussenkomst van de leidinggevende. De budgetten variëren in omvang tussen de $€ 227$ (f 500)) en $€ \mathrm{I} .000$ per jaar en tussen de $€ \mathrm{I} .200$ en $€ 2.500$ per drie jaar. De keuzevrijheid loopt sterk uiteen: van een paar specifieke door het bedrijf zelf geselecteerde leeractiviteiten in het E-miles programma van Philips tot het brede 'leeractiviteiten die gerelateerd zijn aan het werkzame leven en bijdragen aan het CV' van ING. De deelnamepercentages lopen sterk uiteen: van $\mathrm{I}, 3 \%$ tot $45 \%$ en nemen (met uitzondering van het Persoonlijk Ontwikkelings Budget van Shell) toe naarmate de keuzevrijheid voor de deelnemers groter wordt.

\subsection{Pilotprojecten van overheden en sociale partners}

In deze paragraaf worden vijftien pilotprojecten nader beschreven die door overheden of sociale partners zijn geïnitieerd. De eerste vijf pilotprojecten zijn van Nederlandse bodem, terwijl de laatste tien projecten uit diverse EU-landen afkomstig zijn. Net als in de vorige paragraaf worden de projecten eerst in een schematisch overzicht kort gepresenteerd (zie tabel 2.2) waarna een uitgebreide casebeschrijving volgt. 


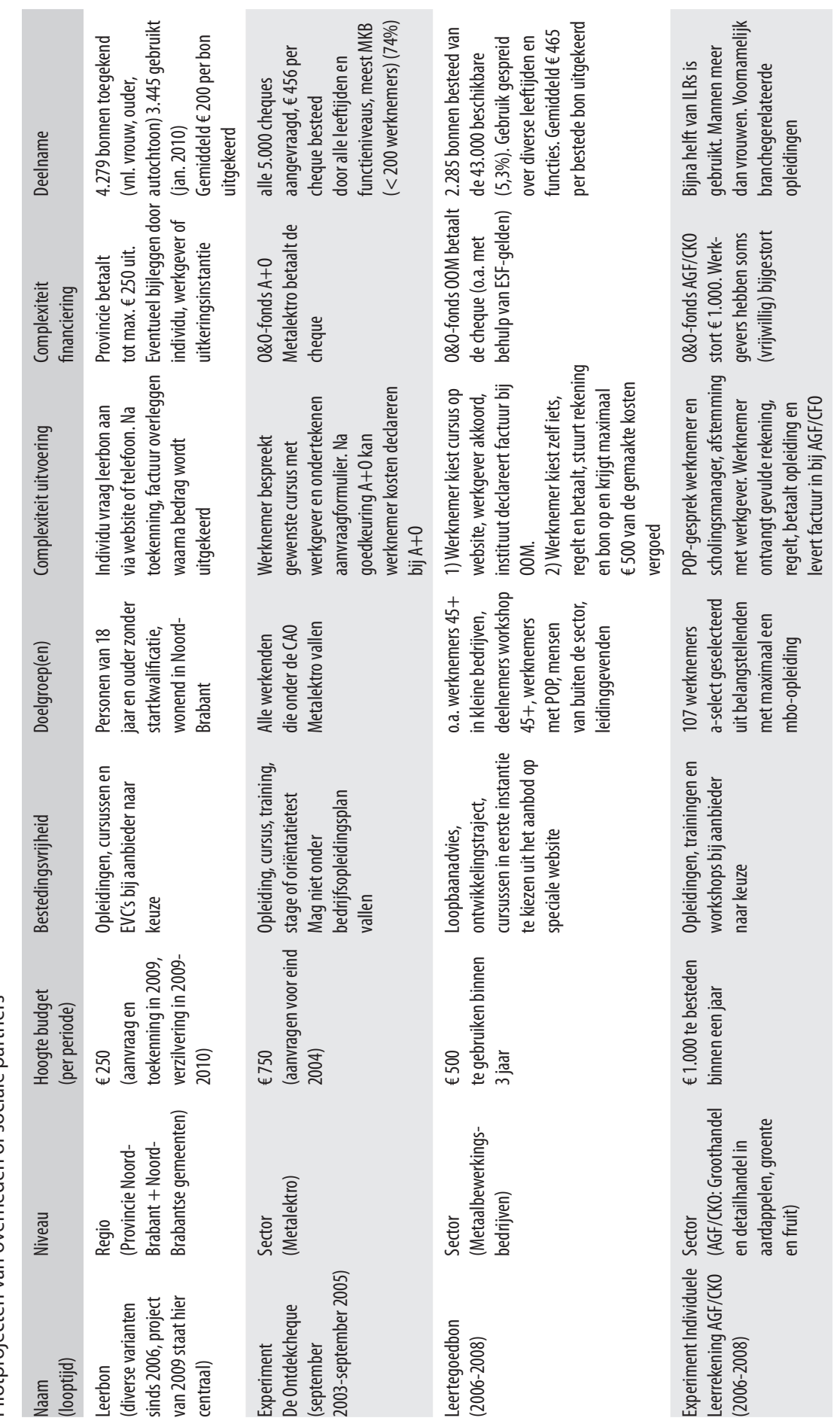




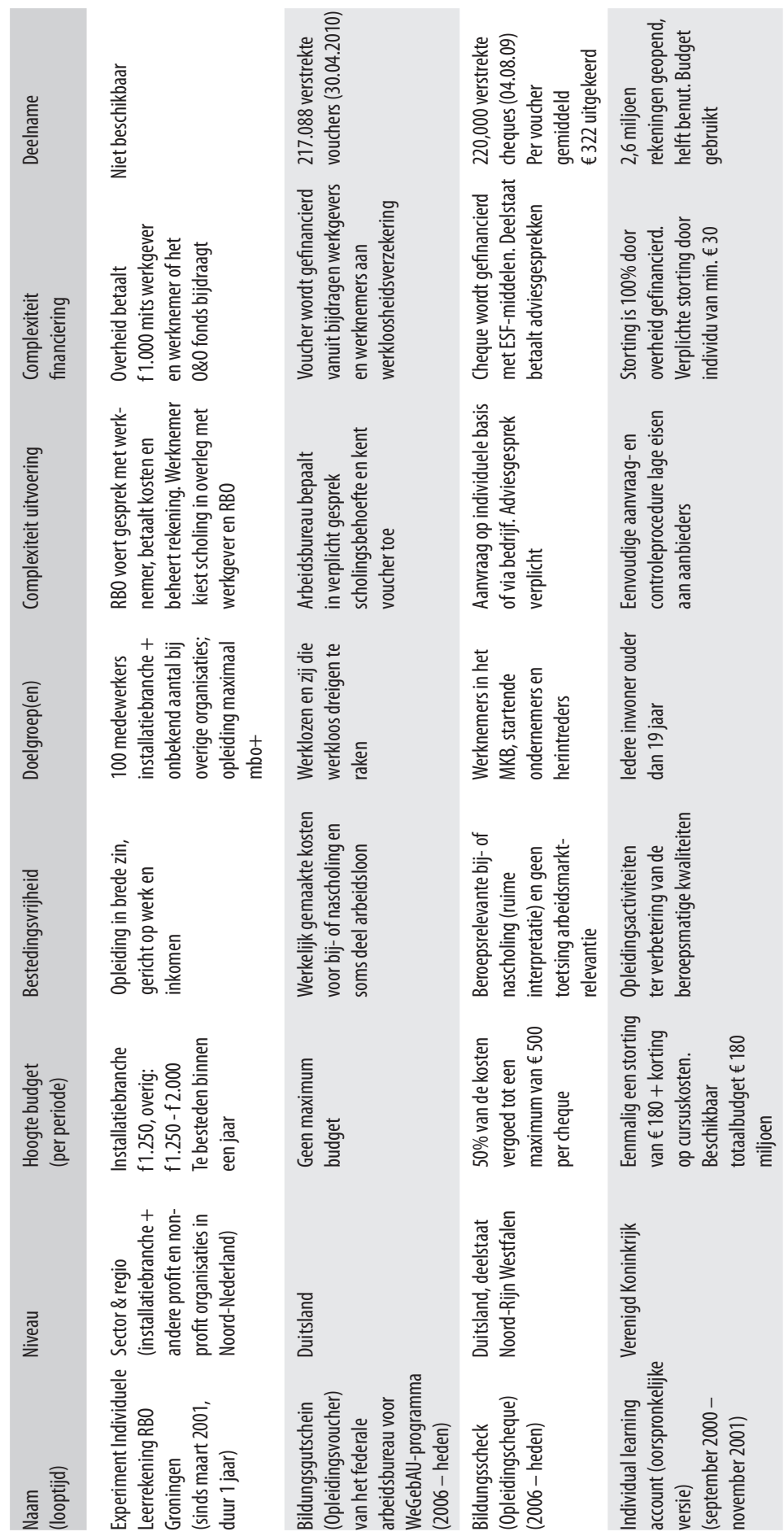




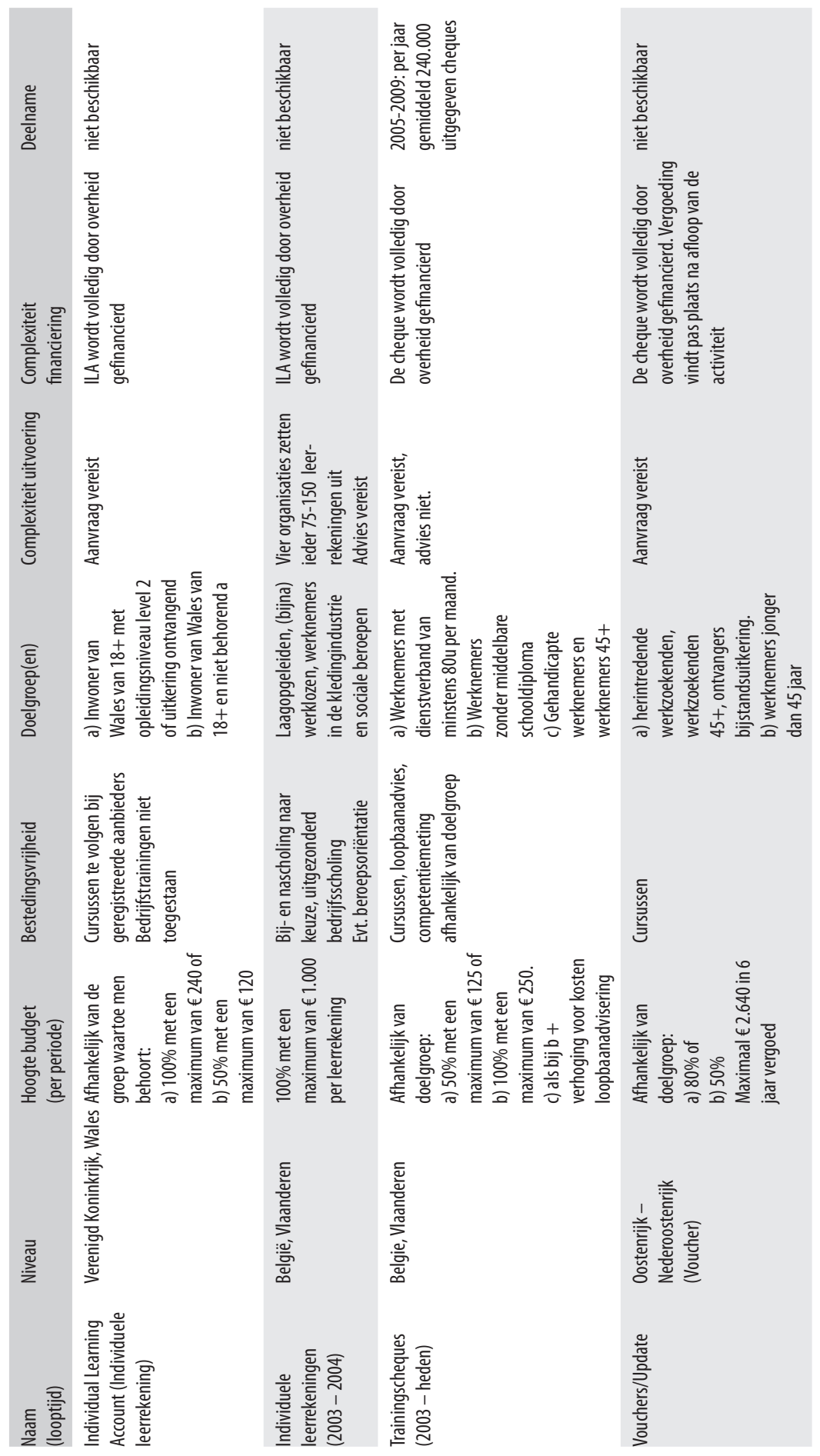


咅
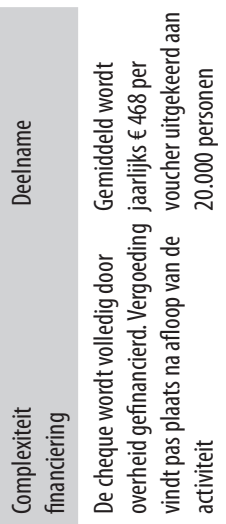

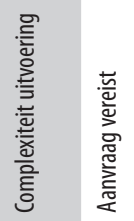
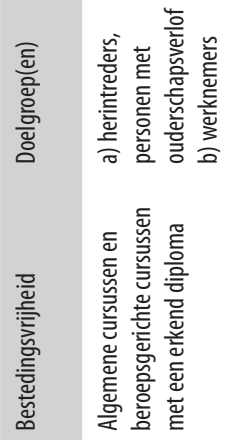
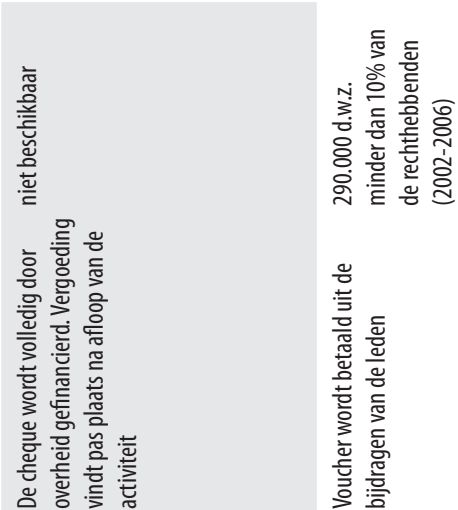

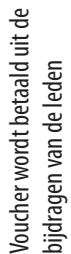
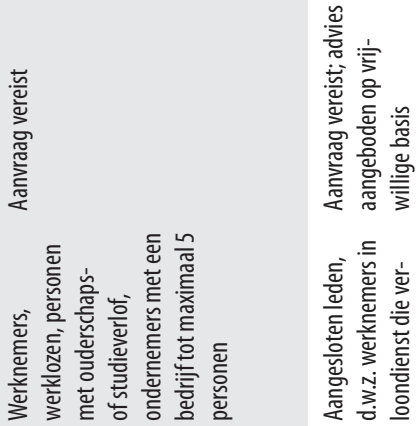

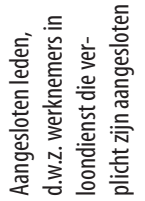
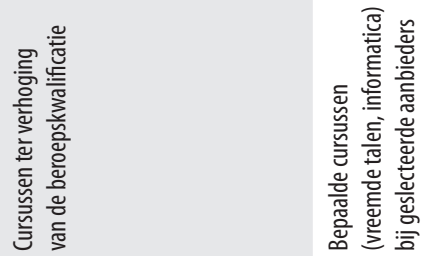

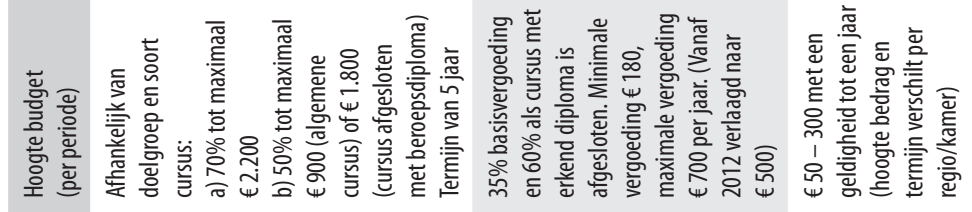

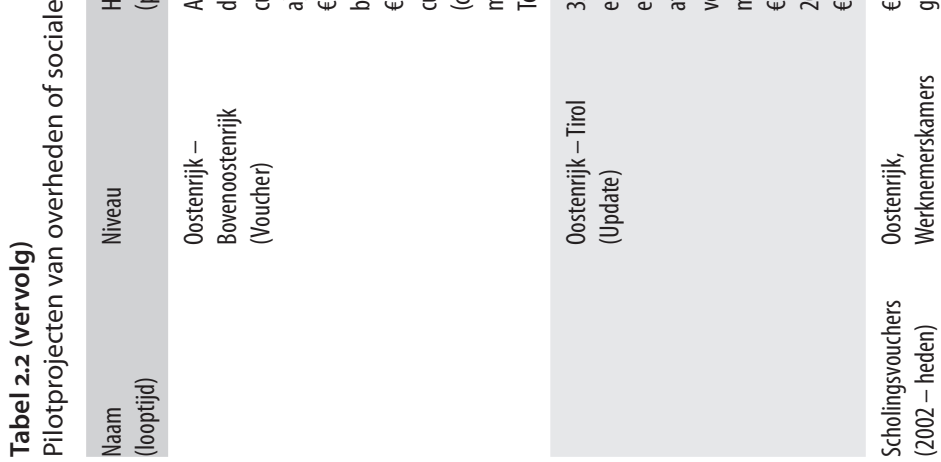



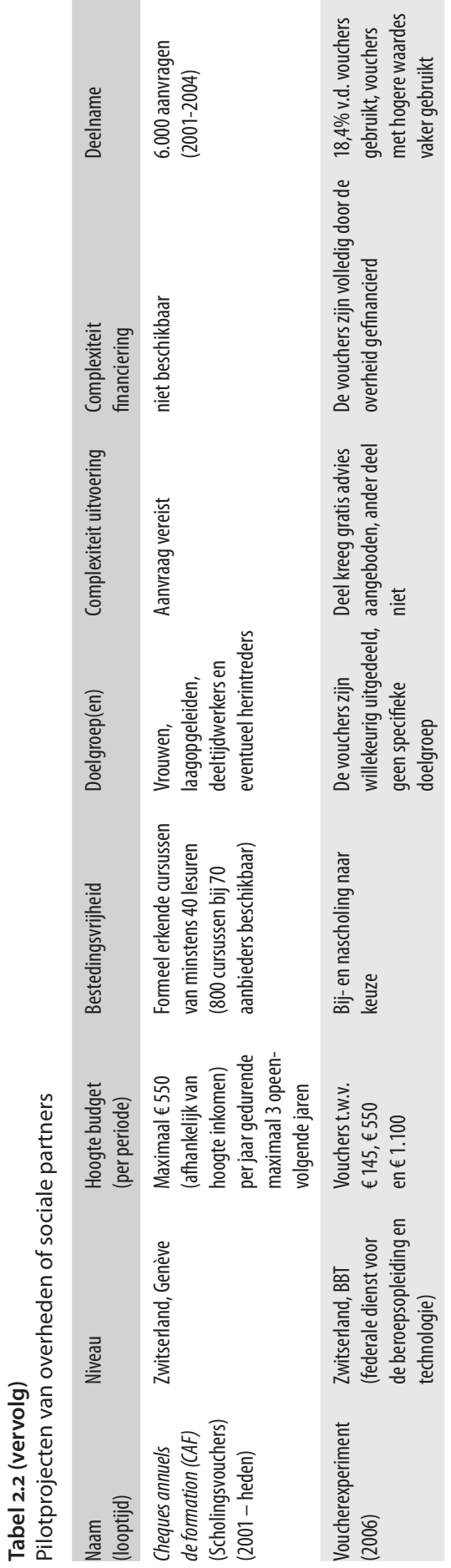


\subsubsection{Leerbon van de provincie Noord-Brabant ${ }^{16}$}

\section{Beschrijving}

Sinds 2006 zijn in de provincie Noord-Brabant diverse leerbon pilots gehouden, zowel op provinciaal als op gemeentelijk niveau. Gebaseerd op deze succesvolle pilots heeft de provincie in 20098.000 leerbonnen van maximaal $€ 250$ beschikbaar gesteld met als doel laagopgeleide Brabanders te verleiden een opleiding of cursus te volgen om zo hun de arbeidsmarkt- en maatschappelijke participatie te bevorderen of versterken.

\section{Uitvoering en beheer}

Inwoners van de provincie Noord-Brabant die minimaal i8 jaar zijn en nog geen startkwalificatie hebben, kunnen de leerbon aanvragen via een zeer eenvoudig digitaal aanvraagformulier op de website www.leerbon.nl of telefonisch. De aanvragen zijn vervolgens behandeld door één van de zes servicepunten Leren en Werken. Na het toekennen van de leerbon wordt het leerbonbedrag overgemaakt nadat de aanvrager de factuur van de gevolgde opleiding of cursus heeft overlegd. Het is ook mogelijk dat het bedrag rechtstreeks wordt overgemaakt aan de cursusaanbieder. De te kiezen aanbieder moet ingeschreven staan bij de Kamer van Koophandel, dit om leren in de vertrouwde omgeving (buurthuis, wijkcentrum) mogelijk te maken en zo de drempel laag te houden.

Communicatie en begeleiding

Via website, lokale kranten, servicepunten Leren en Werken.

\section{Financiering}

De provincie Noord-Brabant heeft deze regeling betaald. Totale kosten bedroegen ongeveer $€ 850.000$.

\section{Resultaat}

In de loop van 2009 zijn alle 8.000 bonnen aangevraagd (8.084 aanvragen, peildatum 4 januari 20IO). 7.356 aanvragen kwamen daadwerkelijk in aanmerking voor een leerbon, maar uiteindelijk zijn er 4.379 leerbonnen toegekend. Dit wordt o.a. veroorzaakt door mensen die niet meer bereikbaar bleken te zijn, de vragenlijst niet hebben teruggestuurd of zichzelf terugtrokken. Per 8 januari 20 IO zijn 3.445 leerbonnen daadwerkelijk uitgekeerd. Per leerbon is gemiddeld $€ 200$ uitgekeerd en deze is besteed aan een cursus die gemiddeld $€ 339$ kostte. Het verschil is door de cursist, de werkgever of de uitkeringsinstantie bijgelegd. De mensen die een leerbon toegekend hebben

I6. Bronnen: Dagevos, J. e.a. (2009), Een duwtje in de rug: Evaluatie van de provinciale leerbonnen, Tilburg: TELOS;

Galema, W. en E. de Beule (2010), Behoefen- en bekendheidsonderzoek Leerbon, Eindrapportage, 's-Hertogenbosch/Eindhoven: CINOP/Markteffect;

Geenen, M.J.D. (20I0), De leerbon doorgelicht: evaluatie leerbon 2009,'s-Hertogenbosch/Mill: Provincie Noord-Brabant/Wise up Arbeidsmarktconsultancy. 
gekregen zijn voornamelijk vrouw (70\%), autochtoon $(87 \%)$ en gemiddeld 53 jaar oud. $38 \%$ van deze personen heeft een betaalde baan, $47 \%$ heeft een uitkering en $15 \%$ is een niet-uitkeringsgerechtigde (ook wel nugger genoemd). De mensen met een toegekende leerbon bleken deze vooral te hebben aangevraagd om zich persoonlijk te ontwikkelen $(42 \%)$ of om werkgerelateerde redenen (31\%). Cursussen op het gebied van ICT en taal zijn veruit het meest gekozen. Het was de bedoeling van de provincie dat met ingang van 2010 de gemeenten de leerbon zouden overnemen en bijvoorbeeld zouden inbedden in hun WMO-activiteiten. Dit is niet gebeurd o.a. omdat een aanzienlijk aantal gemeenten kampt met tekorten in het WMO-budget. Ten tijde van het schrijven van deze rapportage biedt alleen de gemeente 's-Hertogenbosch de leerbon aan.

\subsubsection{Ontdekcheque in de Metalektro ${ }^{17}$}

\section{Beschrijving}

In september 2003 heeft het $\mathrm{O} \& \mathrm{O}$ fonds voor de Metalektro, $\mathrm{A}+\mathrm{O}$, bij wijze van experiment 5.000 Ontdekcheques beschikbaar gesteld met een waarde van $€ 750$ per cheque. De cheques zijn in september 2003 beschikbaar gesteld en moesten voor het einde van 2004 aangevraagd worden.

\section{Uitvoering en beheer}

De cheque kan door werknemers uit deze sector worden besteed aan een opleiding, cursus, training, stage of oriëntatietest zolang deze maar niet onder het bedrijfsopleidingsplan van het bedrijf valt. De werknemer volgt de activiteit in eigen tijd, maar na overleg en goedkeuring van de werkgever is het ook mogelijk om de activiteit onder werktijd te doen. De werknemer vraagt de cheque rechtstreeks aan bij $\mathrm{O} \& \mathrm{O}$-fonds $\mathrm{A}+\mathrm{O}$ door een eenvoudig aanvraagformulier (verkrijgbaar bij werkgever of via internet bij $\mathrm{A}+\mathrm{O}$ ) in te dienen, waarop is aangegeven aan welke activiteit de werknemer de cheque wil besteden en dat door werkgever en werknemer ondertekend is. $\mathrm{Na}$ goedkeuring door $\mathrm{A}+\mathrm{O}$ kan de werknemer de gemaakte kosten rechtstreeks of via de werkgever declareren bij $\mathrm{A}+\mathrm{O}$.

\section{Communicatie en begeleiding}

De Ontdekcheque is o.a. door een mailing vanuit het ledenbestand van het pensioenfonds voor de Metalektro (PME) en via affiches en flyers in bedrijven onder de aandacht gebracht van de werknemers. Ook heeft $\mathrm{A}+\mathrm{O}$ een aantal bedrijfsbezoeken afgelegd om het gebruik van de cheque te stimuleren.

17. Bronnen: Stichting A+O Metalektro (2005), Eindrapportage experiment Ontdekcheque: Employability in de Metalektro september 2003 - september 2005, Leidschendam (interne publicatie); Voorlichtingsbrief aan bedrijven en voorlichtingskrant voor werknemers m.b.t. de Ontdekcheque door Stichting A+O Metalektro verstuurd in 2003 (interne publicaties); dhr. H. de Groot (procesmanager), $\mathrm{A}+\mathrm{O}$. 


\section{Financiering}

De Ontdekcheque en de organisatie ervan is volledig door $\mathrm{A}+\mathrm{O}$ betaald. Hiermee was een bedrag van ongeveer $€ 2,4$ miljoen gemoeid (inclusief $5 \%$ organisatiekosten).

\section{Resultaat}

Alle beschikbare cheques zijn aangevraagd. Meestal werd één activiteit per cheque gefinancierd, maar ongeveer 300 werknemers hebben meerdere activiteiten met hun cheque betaald. Gemiddeld is van elke cheque $€ 456$ daadwerkelijk besteed. Driekwart van de cheques is besteed door werknemers uit bedrijven met minder dan 200 werknemers. De cheque is gebruikt door werknemers van alle leeftijden en functieniveaus. Ongeveer de helft van de gevolgde activiteiten is gericht geweest op employability (d.w.z. niet functiegericht, maar ter verbreding van het huidige werkveld) en ongeveer $40 \%$ op vrijetijdsbesteding. De cheque is nauwelijks gebruikt voor oriëntatietests of stages $(\mathrm{I}, 4 \%)$.

\subsubsection{Leertegoedbon in de Metaalbewerking ${ }^{18}$}

\section{Beschrijving}

Het O\&O-fonds voor het Metaalbewerkingsbedrijf (OOM) heeft begin 2006 leertegoedbonnen beschikbaar gesteld van $€ 500$ voor de werknemers uit deze sector met als doel hun inzetbaarheid te vergroten. De bon is geldig tot eind 2006, wat inhoudt dat de aanvraag voor de bon voor die datum moet zijn gebeurd, anders vervalt de bon. Aangezien dit een eenmalig pilot is, is van cumulatie geen sprake.

\section{Uitvoering en beheer}

De werknemers moeten aan één van de volgende voorwaarden voldoen om voor de bon in aanmerking te komen: deel hebben genomen aan een workshop 45+, een POP hebben opgesteld met een OOM-regiomanager, een EVC-traject volgen, lange tijd geen opleiding hebben gevolgd of zojuist een vakdiploma hebben gehaald of ouder zijn dan 45 jaar en werkend in een klein bedrijf, leidinggevende of zij-instromer zijn. De bon kan worden besteed aan een opleiding of cursus, maar ook aan een loopbaanadvies of een ontwikkelingstraject uit een gelimiteerd aanbod. $\mathrm{Na}$ ontvangst van de leerbon activeert de werknemer deze via de website en maakt een keuze uit het aanbod. De keuze vult de werknemer digitaal in op een formulier dat hij afdrukt, door de werkgever laat ondertekenen en opstuurt naar OOM. Naar aanleiding van deze keuze via internet neemt het cursusinstituut contact op met de deelnemer en na deelname stuurt het cursusinstituut de factuur naar OOM. Wanneer een werknemer een opleiding nodig heeft buiten het standaard aanbod en/of dat duurder is dan $€ 500$, dan is ook de volgende route mogelijk: de werknemer kiest, regelt en betaalt zelf de opleiding en stuurt vervolgens zijn leertegoedbon en de rekening op naar OOM. Vervolgens

I8. Bronnen: dhr. M. van het Schip (projectleider) en mevr. J. Janssen (beleidsmedewerker), OOM; Metaaljournaal Winter 'os-'o6 en Metaaljournaal Zomer 2006 uitgegeven door OOM. 
makk OOM de werkelijke kosten tot een maximum van $€ 500$ aan de werknemer over.

\section{Communicatie en begeleiding}

Speciale website, berichten in het Metaaljournaal, bedrijfsbezoeken door OOM, werkgevers.

\section{Financiering}

De leertegoedbonnen zijn volledig betaald door OOM dat hiervoor o.a. gebruik heeft gemaakt van subsidies uit het Europees Sociaal Fonds (ESF).

\section{Resultaat}

Van de 43.000 beschikbare bonnen zijn er 2.285 besteed $(5,3 \%)$ met een gemiddeld besteed bedrag van $€ 465$. Door gebrekkige animo in het begin is het oorspronkelijke aantal doelgroepen uitgebreid. Het gebruik is verspreid over de leeftijdsgroepen, maar het gebruik onder ouderen is verhoudingsgewijs lager: $37 \%$ van de leerbonnen is gebruikt door werknemers tot en met 35 jaar, $32 \%$ door $36-45$ jarigen, $24 \%$ door 46-55 jarigen en 7\% van de gebruikers is tussen de 56 en de 65 jaar oud. De bon is gebruikt door werknemers met allerhande functies en functieniveaus zoals productiemedewerkers, administratief medewerkers, engineers en directeuren. Ook de gekozen cursussen beslaan een breed spectrum. Ongeveer een derde van de bonnen is besteed aan vaktechnische cursussen (o.a. verspaning, CAD en elektrotechniek), een derde aan niet-technische vakcursussen (o.a. administratief/commercieel, automatisering en personeelszaken), ruim $20 \%$ aan algemene cursussen (o.a. talen en communicatie) en $15 \%$ aan managementcursussen. De leertegoedbon is inmiddels vervangen door een andere regeling, de persoonlijke trainingstoelage (PTT).

\subsubsection{Experiment Individuele Leerrekening AGF/CKO ${ }^{19}$}

\section{Beschrijving}

In de sector AGF (groothandel en detailhandel voor aardappels, groenten en fruit) heeft een aantal werknemers in de periode 2006/2007 de beschikking gekregen over een Individuele Leerrekening (ILR) van $€$ I.ooo. De ILR is aan een aantal werknemers in de AGF sector uitgereikt in het kader van een experiment uitgevoerd door ECBO onder werknemers uit een viertal sectoren met maximaal een mbo-opleiding. Het AGF Centrum voor Kennis en Ontwikkeling (AGF/CKO) heeft 2Io deelnemers geworven (o.a. door vrijwillige aanmelding) waarvan ongeveer de helft, IO7 personen, een Individuele Leerrekening (ILR) heeft ontvangen, de andere helft fungeerde als controlegroep en ontving geen ILR.

19. Bronnen: Doets, C. en T. Huisman (2009), De effectiviteit van een Individuele Leerrekening, 's-Hertogenbosch/Amsterdam: Ecbo; dhr. M. Stolwijk (scholingsmanager), AGF/CKO. 


\section{Uitvoering en beheer}

Alleen werknemers met maximaal een mbo-opleiding hebben zich aan kunnen melden voor een ILR welke binnen een jaar is te besteden aan een opleiding, cursus of workshop bij een aanbieder naar keuze. Met elke deelnemer die een ILR heeft ontvangen is een POP-gesprek gevoerd door een scholingsmanager van AGF/CKO om de leerwens en de bijbehorende opleiding, cursus of workshop te formuleren. Deze leerwens is met de werkgever afgestemd en in geval van grote discrepantie is een vervolggesprek gehouden met werkgever, werknemer en scholingsmanager. De werknemer regelt vervolgens zelf de opleiding en betaalt deze van de ILR. De ILR bestaat in dit experiment namelijk uit een daadwerkelijke bankrekening, waarop het AGF/CKO $€$ I.O०o heeft gestort. Ter controle overlegt de werknemer de nota van de opleidingsaanbieder aan AGF/CKO.

Communicatie en begeleiding

Scholingsmanagers van $\mathrm{AGF} / \mathrm{CKO}$ en de werkgevers.

\section{Financiering}

AGF/CKO heeft het bedrag van $€$ I.ooo per ILR betaald. Daarnaast hebben sommige werkgevers vrijwillig een bijdrage hier aan toegevoegd wanneer de gekozen cursus meer dan $€ \mathrm{I} .000$ kostte.

\section{Resultaat}

Het aanvankelijke enthousiasme voor het experiment onder de werknemers in de sector was niet groot: AGF/CKO heeft zich moeten inspannen om de deelnemers aan het experiment te werven (ondanks de $€$ I25 die elke deelnemer kreeg, ILR-ontvanger of niet). Ongeveer de helft van de ILR-bezitters heeft (een deel van) het bedrag daadwerkelijk gebruikt. Volgens AGF/CKO is gemiddeld $€ 700$ per ILR besteed. De ILR was vaak niet toereikend om de gekozen cursus volledig te financieren en werd daarom aangevuld door een bijdrage van de werkgever of een bijdrage van de werknemer. Mannen hebben de ILRs vaker gebruikt dan vrouwen en het gebruik was ook groter onder de werknemers vanaf 35 jaar. De ILR heeft tot meer cursusdeelname geleid: van de ILR-ontvangers heeft $70 \%$ een cursus gevolgd tegenover 50\% van de nietILR-ontvangers. Het gebrek aan opbrengst en enthousiasme in combinatie met de al aanwezige ruime subsidiemogelijkheden in de sector via de werkgevers heeft geleid tot de beslissing om de ILR geen vervolg te geven. Vanuit AGF/CKO denkt men dat het profiel van de sector (kleine familiebedrijven, lange werkdagen, veel herintreders, self-made) er voor zorgt dat de sector niet zo vertrouwd is met opleiden. ${ }^{20}$

20. Uit het onderzoek onder alle deelnemers afkomstig uit de vier sectoren blijkt dat werknemers met een ILR in een bedrijf met minder dan 20 werknemers minder vaak een opleiding volgen dan ILR-bezitters werkzaam in een bedrijf met 20 of meer werknemers. 


\subsubsection{Experiment Individuele Leerrekening RBO Groningen ${ }^{21}$}

\section{Beschrijuing}

In maart 200I heeft het Regionaal Bureau Onderwijs (RBO) Groningen bij wijze van experiment een aantal Individuele Leerrekeningen (ILR) met daarop minstens f I.000 verdeeld onder werknemers van bedrijven in de installatiebranche en onder werknemers van bedrijven in het $\mathrm{MKB}$, grootbedrijf, gemeentelijke instellingen en not-forprofitinstellingen in Noord-Nederland. Het ILR-bedrag moet binnen een jaar besteed worden. Omdat het een eenmalig experiment betreft, is cumulatie niet mogelijk.

\section{Uitvoering en beheer}

De doelgroep van dit ILR-experiment bestaat uit werknemers die een scholingsachterstand hebben of behoefte hebben om hun kennis en vaardigheden verder te ontwikkelen. Hun opleidingsniveau is doorgaans laag tot maximaal mbo+. De ILR mag worden besteed aan opleidingen in brede zin gericht op werk en inkomen. In de installatiebranche hebben Ioo werknemers een ILR ontvangen. Het aantal verstrekte ILRs in de overige deelnemende organisaties is niet bekend. Voorafgaand aan het experiment zijn er door RBO samenwerkingsovereenkomsten met de werkgevers opgesteld. De werkgever benadert vervolgens potentiële deelnemers die met RBO Groningen een gesprek hebben over de opleidingsvraag en advies ontvangen over de scholingsmogelijkheden. De deelnemer bepaalt zijn of haar scholing, maar wel in overleg met werkgever en RBO.

\section{Communicatie en begeleiding \\ Werkgevers en RBO.}

\section{Financiering}

De rekening wordt door de overheid gevuld met $\mathrm{f}$ I.00o op voorwaarde dat zowel werkgevers en werknemers ook bijdragen met een bedrag tussen de $f 250$ en $f$ I.000. Hierover verschillen de afspraken per organisatie. In het geval van de installatiebedrijven stort het Opleidings- en ontwikkelingsfonds voor het Technisch InstallatieBedrijf (OTIB) f 250 uit naam van de werkgever en werknemer tezamen op elke ILR.

\section{Resultaat}

Er zijn geen gegevens bekend over het precieze gebruik van de ILRs. Wel blijkt dat werkgevers de door de overheid minimaal vereiste bijdrage hebben gestort waardoor de motivatie voor werknemers om bij te dragen gering is geweest. Het experiment heeft laten zien dat ondersteuning en begeleiding van de werknemers heel belangrijk is bij het vinden van de juiste scholing.

2I. Bron: De Korte, A.W. e.a. (200I), Eindrapport verkenning van de POR: een onderzoek naar de mogelijkheden tot invoering van een persoonlijke ontwikkelingsrekening in Nederland, Utrecht: Berenschot en PriceWaterhouseCoopers. 


\subsubsection{WeGebAU, stimulering door het federale arbeidsbureau (Duitsland) ${ }^{22}$}

\section{Beschrijving}

In het subsidieprogramma WeGebAU vergoedt het federale arbeidsbureau de werkelijk gemaakt kosten van bij- of nascholingen en in sommige gevallen een deel van het arbeidsloon. Het programma is in 2006 van start gegaan en is in ieder geval tot en met $20 I 0$ van kracht geweest.

\section{Uitvoering en beheer}

De doelgroep bestaat uit (I) laagopgeleiden, (2) werknemers die ouder zijn dan 45 jaar en werkzaam zijn in bedrijven met minder dan 250 werknemers, (3) personen die in verband met arbeidstijdverkorting deelnemen aan bij- of nascholing en na afloop van de verkorte werktijd door WeGebAU verder gesteund zouden kunnen worden, en (4) werknemers die hun beroepsdiploma minstens vier jaar geleden hebben behaald en/of die in de afgelopen vier jaar niet hebben deelgenomen aan door de overheid gefinancierde bij- of nascholing. Advies bij aanvraag van WeGebAU is wettelijk verplicht en moet worden gegeven door het federale arbeidsbureau. De bemiddelingsdeskundige/ scholingsadviseur geeft daarbij informatie over de subsidiemogelijkheden en uitleg over de basisvoorwaarden voor subsidiëring. Ook stelt de bemiddelingsdeskundige de behoefte aan bij- of nascholing vast. Het federale arbeidsbureau beslist over de subsidiëring.

De bij- of nascholing moet verder gaan dan een kortstondige arbeidsplaatsgerelateerde aanpassingsactiviteit en plaatsvinden buiten het bedrijf waarbij de medewerker in dienst is. De aanbieders van bij- en nascholing moeten door de overheid erkend zijn en voldoen aan bepaalde eisen. De deelnemer kan de scholingsvoucher binnen de geldigheidsduur bij een goedgekeurde aanbieder naar keuze inwisselen voor deelname aan een goedgekeurde activiteit met een scholingsdoel dat past bij de scholingsvoucher. Bedrijven mogen de subsidie ook aanvragen, maar hiermee mogen geen bedrijfsscholingsactiviteiten worden gefinancierd.

\section{Financiering}

Het programma wordt gefinancierd uit de middelen van het federale arbeidsbureau en derhalve uit de bijdragen van werkgevers en werknemers aan de werkloosheidsverzekering. In 2010 bedroeg deze bijdrage $2,8 \%$ van het bruto maandsalaris.

22. Bronnen:

http://www.icos-akademie.de/foerdermittel/foerderprogramm-wegebau/wegebau-info-a-z (I7 december 20IO); Lott, M. en E. Spitznagel (2010), Impulse für die berufliche Weiterbildung im Betrieb. IAB-Kurzbericht II/20IO. http://www.upl-lichtenberg.de/servlets/sfs;jsessionid=3DCDoo $\mathrm{BB}_{48080}{ }_{9} \mathrm{EE}_{37} 58 \mathrm{~F}_{9} 6 \mathrm{EE}_{4} \mathrm{EF}_{9} \mathrm{E}_{9}$ ? $\mathrm{s}=$ WykHisHESAvbj4fEwJa\&t=/documentManager/sfdoc.file. supply\&e=UTF-8\&i=II402220I $5742 \& \mathrm{l}=\mathrm{I} \&$ fileID=I244703750837 (I7 december 20IO); http://doku. iab.de/chronik/3I/2006 02 30 3I Wegebau.pdf (I7 december 20IO). 


\section{Resultaat}

In totaal zijn tussen 2007 en eind april 2010 217.088 subsidieverzoeken ingewilligd. Laagopgeleiden maken drie keer zo vaak gebruik van de regeling dan werknemers ouder dan 45 jaar. Twee derde van de gebruikers is man, een derde vrouw. Het gebruik van de subsidieregeling WeGebAU neemt vooral bij middelgrote en grote bedrijven toe. Daarentegen wordt de subsidie nog weinig gebruikt in kleine bedrijven en in bedrijven waar minstens 30\% van het personeel laag is opgeleid. De bekendheid van het programma onder bedrijven is groeiende, al geldt dit meer voor bedrijven vanaf Ioo werknemers dan voor de kleinere bedrijven. Deze grotere bedrijven maken ook meer gebruik van de regeling dan de kleinere: in 2008 gebruikte ruim $40 \%$ van de grotere bedrijven de regeling tegenover een kwart van de kleinere bedrijven.

\subsubsection{Bildungsscheck Nordrhein-Westfalen (Duitsland) ${ }^{23}$}

\section{Beschrijving}

De "Bildungsscheck NRW" is begin 2006 ingevoerd door het ministerie van Werkgelegenheid, Volksgezondheid en Maatschappelijk Werk van de deelstaat Nordrhein-Westfalen en is in de loop der tijd meerdere keren aangepast. Door de grote vraag naar vouchers en de landelijke invoering van de scholingspremie is de regeling eind 2008 versoberd: werknemers kunnen jaarlijks maximaal één scholingsvoucher krijgen via individuele toegang en werkgevers in het MKB kunnen maximaal tien vouchers per jaar aanvragen via toegang bedrijf. Met de scholingsvoucher kan telkens één bij- of nascholingsactiviteit die inhoudelijk op de scholingsvoucher vermeld staat, voor de helft worden betaald met een maximum van $€ 500$ per voucher.

\section{Uitvoering en beheer}

De scholingsvoucher is bestemd voor werknemers in loondienst van het MKB, startende ondernemers in de eerste vijf jaar en herintreders mits deze in het jaar van afgifte van de scholingsvoucher en/of in het voorgaande jaar niet hebben deelgenomen aan bij- of nascholing. Met de voucher kan beroepsrelevante bij- of nascholing worden betaald, wat ruim wordt geïnterpreteerd. Een adviesgesprek met een adviesdienst, waarin het voldoen aan de toelatingsvoorwaarden alsmede de subsidieerbaarheid van de activiteit worden vastgesteld, is verplicht. Er wordt echter niet op arbeidsmarktrelevantie getoetst. De aanbieders van bij- of nascholing moeten officieel erkend zijn en voldoen aan bepaalde certificeringseisen. De rekening van de scholing moet op naam van de persoon (individuele toegang) of het bedrijf (bedrijfstoegang) worden gesteld.

23. Bronnen: http://www.arbeit.nrw.de/pdf/arbeit/bildungsscheck_info_zugang_20Io_06_28.pdf (8 september 20IO); Onderzoek verricht onder ontvangers van de vouchers door het Gesellschaft für innovative Beschäftigungsförderung (G.I.B.); SALSS (2008), Evaluierung des „Bildungsscheck NRW“: Endbericht, Bonn: Sozialwissenschaftliche Forschungsgruppe. 


\section{Financiering}

De voucher wordt gefinancierd via ESF-middelen. Eind maart is voor ongeveer I09.000 ingewisselde vouchers $€ 35,2$ miljoen subsidie verleend. Dit komt neer op een uitkering van ongeveer $€ 322$ per voucher. De advieskosten zijn betaald door de deelstaat Nordrhein-Westfalen.

\section{Resultaat}

Sinds de invoering in januari 2006 tot eind maart 2008 werden in totaal 236.477 scholingsvouchers verstrekt in NRW (42\% op individuele basis, de rest via bedrijfsaanvragen) waarvan eind maart $46 \%$ was ingewisseld. Dit percentage stijgt vermoedelijk nog naar $70 \%$. 58\% van de in 2007 gebruikte vouchers is verzilverd door vrouwelijke werknemers. Werknemers met een buitenlandse nationaliteit gebruiken de scholingvoucher zelden. II\% van de ontvangers van een scholingsvoucher heeft een diploma "Hauptschule", een laag of in het geheel geen diploma. 31\% beschikt over een diploma op middelhoog niveau, terwijl $58 \%$ een diploma van een hogeschool of universiteit heeft. Met betrekking tot de leeftijd en nationaliteit zijn er daarentegen slechts zeer kleine verschillen. Laagopgeleiden worden beter bereikt via de ondernemingen.

\subsubsection{Individual Learning Accounts, ILAs (Verenigd Koninkrijk) ${ }^{24}$}

\section{Beschrijving}

Deze regeling is in september 2000 ingevoerd door de regering en in november $200 \mathrm{I}$ weer afgeschaft. De regeling bestond uit een leerrekening geopend bij een bank waar de overheid $£ 150$ ( $€$ I80) op voorwaarde dat het individu minstens $£ 25$ ( $€ 30$ ) stortte. De deelnemers kregen tevens een korting van $20 \%$, met een maximum van $£$ IOO ( $€$ I 20$)$, op de cursustarieven bij standaardcursussen en van $80 \%$, met een maximum van $£ 200$ ( $€ 240$ ), voor cursussen op het gebied van communicatie, rekenen en basisinformatica. Het beschikbare budget kon voor meerdere activiteiten worden gebruikt, maar verviel indien het aan het einde van het jaar nog niet gebruikt of opgebruikt was.

\section{Uitvoering en beheer}

De ILA kon worden aangevraagd door elke burger die ouder was dan i9 jaar en een leerrekening bij een bank had geopend. Met het geld dat op de leerrekening werd gestort, konden opleidingsactiviteiten ter verbetering van de beroepsmatige kwaliteiten bij geregistreerde aanbieders worden ingekocht. De registratie-eisen waren licht. Er vond geen advisering of andere begeleiding van individuele personen plaats en ook geen toetsing op arbeidsmarktrelevantie. Het model werd bewust zo onbureaucratisch mogelijk gehouden en had als één van de doelen het aanbod van bij- en nascholing uit te breiden en nieuwe aanbieders op de markt te krijgen.

24. Bron: McLaughlin, Daniel (2007), Individual Learning Accounts - Lesson Learned: England, paper presented at the Regional Offices of Administration, Florence (Tuscany, Italy). 


\section{Financiering}

De regering had een budget beschikbaar van $£$ I5O miljoen ( $€$ I80 miljoen) voor twee jaar, genoeg voor één miljoen leerrekeningen. Hoewel in het eerste jaar 2,6 miljoen rekeningen werden geopend, is dit budget niet dramatisch overschreden aangezien ongeveer de helft van deze rekeningen niet werden benut en de regering het gestorte bedrag na opheffing van de rekening weer terugkreeg.

\section{Resultaat}

De regeling is voortijdig stopgezet en vervolgens afgeschaft. Dit werd enerzijds veroorzaakt door het enorme succes: binnen het eerste jaar waren al 2,6 miljoen rekeningen geopend terwijl er budget was voor I miljoen rekeningen in twee jaar. Anderzijds makkte een klein aantal aanbieders misbruik van de regeling deels door te weinig kwaliteit te leveren en deels door regelrechte fraude, tot het vervalsen van handtekeningen toe. De doelstelling om het aanbod van scholing en het aantal aanbieders te vergroten is gehaald, hoewel niet altijd met de gewenste kwaliteit.

\subsubsection{Individual Learning Accounts, ILAs (Wales) ${ }^{25}$}

\section{Beschrijving}

Deze ILA is volgens een heel ander model opgezet, waarbij men heeft geprobeerd te leren van de fouten bij de oorspronkelijke VK-brede ILA. In deze variant ontvangt men $£$ IOO $(€$ I2O) tot maximaal $£ 200(€ 240)$ per jaar om een cursus te kunnen betalen. De eigen bijdrage varieert al naar gelang de kosten van de cursus en tot welke doelgroep men behoort (zie Uitvoering en beheer).

\section{Uitvoering en beheer}

De maatregel geldt voor I8-jarigen en ouder die woonachtig zijn in Wales. Daarnaast worden twee doelgroepen onderscheiden. De eerste groep bestaat uit personen die een opleidingsniveau hebben van hoogstens Level 2 óf een sociale uitkering ontvangen óf waarvan de partner een sociale uitkering ontvangt. Deze groep ontvangt maximaal $£ 200$ ( $€ 240)$ per jaar voor een cursus en is een eigen bijdrage alleen vereist wanneer de kosten van de cursus hoger zijn dan $£ 200$ (€240). De tweede groep bevat iedereen van minimaal i8 jaar die niet tot de eerste groep behoort. Voor de personen in de tweede groep wordt via de ILA 50\% van de cursuskosten, met een maximum van $£$ IOO ( $€$ I2O) vergoed. Overige eisen zijn dat bedrijfsscholingen niet voor subsidie in aanmerking komen en dat de cursus gevolgd moet worden bij een geregistreerde aanbieder. Er vindt geen toetsing plaats van de arbeidsmarktrelevantie van de gekozen cursus.

Communicatie en begeleiding

Er is niet voorzien in advies of begeleiding.

25. Bron: Welsch Assembly Government (20I0), Individual Leaning Accounts Wales op http://wales.gov. uk/topics/educationandskills/learners/I6plusineducation/fe/ila/?skip=I\&lang=en (I5 september 20IO). 


\subsubsection{Individuele leerrekeningen Vlaanderen (België)}

\section{Beschrijuing}

In België heeft het Vlaamse gewest in het jaar 2002 een modelproject Leerrekeningen opgezet, waarmee personen vouchers voor bij- of nascholing kunnen krijgen. Door middel van een aanbesteding werden vier bemiddelingsorganisaties geselecteerd, die deelnamen aan verschillende uitvoeringen en opzetten voor dit proefproject. Elke organisatie moest tussen de 75 en I5O rekeningen openen, die elk door de overheid met $€ \mathrm{I} .000$ werden medegefinancierd. Het proefproject liep van begin 2003 tot begin 2004 .

\section{Uitvoering en beheer}

Twee van de vier bemiddelingsorganisaties richtten zich op laagopgeleiden (respectievelijk werklozen of personen die kans liepen werkloos te worden) terwijl de twee andere zich concentreerden op werknemers in de kledingindustrie en de sociale beroepen. Daaraan gekoppeld was ook een verscheidenheid aan aanbod, waaronder voor werklozen of vertegenwoordigers van maatschappelijke minderheden en risicogroepen, ook beroepsoriëntatie viel. Bedrijfsscholing kwam niet voor vergoeding in aanmerking en voor zover bekend vond geen toetsing op arbeidsmarktrelevantie plaats.

Communicatie en begeleiding

Bij de leerrekening is advies vereist.

\section{Financiering}

De overheidssubsidie bedroeg maximaal $€$ I.00o waardoor de totale kosten voor het Vlaamse gewest op maximaal $150 \times 4 \mathrm{x} € \mathrm{I} .000=€ 600.000$ zouden uitkomen.

\subsubsection{Trainingscheques Vlaanderen (België) $)^{26}$}

\section{Beschrijving}

Naast het proefproject met leerrekeningen (zie paragraaf 2.3.Io) werd in september 2003 ook een trainingscheque voor werknemers ingevoerd. Deze cheques dekken 50\% van de kosten en vergoeden maximaal $€$ I25 per cursus per jaar. De eigen bijdrage van de werknemers is dus minstens 50\% van de directe bij- of nascholingskosten. Voor sommige doelgroepen geldt een ruimere vergoeding (zie Uitvoering en beheer).

26. Augustyns, M. e.a. (2009), Individual learning accounts in Flanders, in Cedefop: Individual learning accounts, Cedefop Panorama series I63, Luxembourg: Cedefop; VDAB (2008), Jaarverslag 2008, Brussel: Vlaamse Dienst voor Arbeidsbemiddeling en Beroepsopleiding;

VDAB (2009), Jaarverslag 2009, Brussel: Vlaamse Dienst voor Arbeidsbemiddeling en Beroepsopleiding. 


\section{Uitvoering en beheer}

Voorwaarde voor het verkrijgen van de cheque is een dienstverband, eventueel een overeenkomst voor beperkte tijd ("tijdelijke kracht"), mits de arbeidstijd minstens 80 uur per maand bedraagt. De cheque kan vervolgens worden ingewisseld voor cursussen bij erkende scholingsinstituten of worden gebruikt voor beroepsoriëntatie (loopbaanadvies, competentiemeting). Er zijn geen thematische of beroepsspecifieke beperkingen met betrekking tot de aard van de bij- of nascholing en er vindt geen toetsing plaats van de arbeidsmarktrelevantie. Bedrijfsscholing komt echter niet voor vergoeding in aanmerking. Verder moeten de activiteiten buiten de normale werktijd plaatsvinden. Personen zonder middelbareschooldiploma krijgen een tegemoetkoming van maximaal $€ 250$ per jaar zonder eigen bijdrage. Verder kan bij gehandicapte en oudere werknemers (vanaf 45 jaar oud) het subsidiebedrag worden verhoogd met de kosten van loopbaanadvisering, bijvoorbeeld wanneer het loopbaanadvies direct tot bij- of nascholing leidt.

\section{Communicatie en begeleiding}

Anders dan bij de leerrekening is bij de trainingscheque geen advies vereist, maar gaat het uitsluitend om een financiële tegemoetkoming.

\section{Resultaat}

Ongeveer de helft van de gebruikers heeft een universitaire opleiding afgerond en circa $15 \%$ is laag opgeleid, hoewel $24 \%$ van alle werknemers in Vlaanderen tot deze groep behoort. De beschikbare cijfers over het gebruik van trainingcheques in Vlaanderen gedurende de jaren $2005 \mathrm{t} / \mathrm{m} 2009$ laten een gestage toename van het jaarlijks verstrekte aantal cheques en de daarvoor uitgetrokken middelen zien; in 2005 ging het om ongeveer $€ 25$ miljoen, in 2009 al om circa $€ 37,5$ miljoen. Jaarlijks worden gemiddeld circa 240.000 cheques afgegeven.

\subsubsection{Scholingsrekeningen en vouchers van de deelstaten (Oostenrijk) ${ }^{27}$}

\section{Beschrijving, Uitvoering en beheer}

De meeste Oostenrijkse deelstaten stimuleren de individuele bij- en nascholing met behulp van vouchers of vergelijkbare instrumenten, waarbij er aanzienlijke verschillen zijn in de hoogte van de tegemoetkoming, de doelgroep, het voor vergoeding in aanmerking komende scholingsaanbod en de naam. Het principe is echter altijd hetzelfde: de betrokkenen krijgen een deel van de kosten na afloop van een bij- of nascholingsactiviteit vergoed. Hieronder volgen enkele voorbeelden:

27. Dohmen, D. (2007), Aktuelle Trends der nachfrageorientierten Weiterbildungsfinanzierung in Europa: Eine Synopse, FiBS-Forum Nr. 40, Berlin: FiBS; Eichbauer, C. (2007), Weiterbildungsfinanzierung in Österreich, Auszug aus WISO 4/2007, Linz: WISO; Bauer, F. (2009), Individual learner accounts in Upper Austria, in Cedefop: Individual learning accounts, pp. 25-33, Luxembourg: Cedefop. 
In de deelstaat Niederösterreich wordt voor werknemers jonger dan 45 jaar en ontvangers van een vergoeding voor kinderopvang 50\% van het cursustarief, tot maximaal $€ 2.640$, vergoed in een tijdsperiode van zes jaar. Herintreders na ouderschapsverlof die bij de AMS als werkzoekend geregistreerd staan, werknemers ouder dan 45 jaar en bijstandsgerechtigden ontvangen een hogere tegemoetkoming van $80 \%$ van het cursusgeld. Niet-gebruikte tegoeden kunnen in deze tijd worden gebruikt voor verdere scholingsactiviteiten. Als de aanvrager al een tegemoetkoming van de werkgever of een andere subsidieverlener ontvangt, wordt 50\% tot $80 \%$ van het verschil met de totale kosten vergoed.

De deelstaat Oberösterreich vergoedt 50\% van de kosten, met een maximum van $€ 900$ voor bij- en nascholingscursussen en een maximum van $€ \mathrm{I} .800$ voor scholingsactiviteiten met een beroepsdiploma, mits deze beroepsgerelateerd zijn, aan bepaalde kwaliteitsnormen voldoen en met succes worden afgesloten. De looptijd bedraagt maximaal vijf jaar. Voor personen met ouderschapsverlof of herintreders wordt de tegemoetkoming verhoogd tot $70 \%$ met een totaalbedrag van $€ 2.200$.

In Tirol kunnen activiteiten ter verhoging van de beroepskwalificatie worden gefinancierd met een zogenaamde scholingsgeld "update". Deze ondersteuning is eenmalig en bestaat uit een basistegemoetkoming van maximaal $35 \%$ van het cursusgeld met een minimum van $€ \mathrm{I} 80$ en een maximum van $€ 700$ per jaar. Als met de cursus een publiekrechtelijk erkend diploma wordt behaald, wordt na een met succes afgelegd afsluitend examen nog eens $25 \%$ van het cursusgeld als extra tegemoetkoming uitgekeerd, wanneer het cursusgeld minstens $€ 500$ bedraagt. De jaarlijkse extra tegemoetkoming bedraagt maximaal $€ 500$. Vanaf 2012 zal het subsidiebedrag worden verlaagd. Vanaf dan wordt slechts $30 \%$ in plaats van $35 \%$ en nog slechts $€ 500$ in plaats van $€ 700$ vergoed. Met "Update" kunnen werknemers, werklozen, personen met ouderschaps- of studieverlof, zelfstandige ondernemingen in handel en nijverheid met maximaal vijf werknemers een tegemoetkoming krijgen.

\section{Resultaten}

Jaarlijks stelt Oberösterreich $€ 9,5$ miljoen beschikbaar het stimuleren van beroepsmatige bij- en nascholing, waarvan ongeveer 20.000 werknemers profiteren. Het gemiddelde bedrag dat wordt uitgekeerd bedraagt $€ 468$.

\subsubsection{Scholingsvouchers van de werknemerskamers}

\section{Beschrijving}

Naast de deelstaten bieden ook de regionale werknemerskamers sinds 2002 hun leden scholingsvouchers voor bij- en nascholing aan. Deze leden zijn werknemers in loondienst die verplicht bij deze kamers zijn aangesloten. De vouchers hebben waardes variërend van $€ 50$ tot $€ 200$ en soms $€ 300$ (afhankelijk van de regio) en moeten 
doorgaans allemaal binnen het betreffende jaar of semester worden ingewisseld, anders komen ze te vervallen.

\section{Uitvoering en beheer}

Met dit instrument kunnen alle drie miljoen leden van de werknemerskamers worden bereikt, maar in enkele regio's zijn er beperkingen met betrekking tot de doelgroep, zodat scholingsvouchers alleen aan bepaalde personen worden verstrekt, bijvoorbeeld herintreders. De vouchers kunnen slechts bij geselecteerde cursusaanbieders - doorgaans Berufsförderungsinstitute (BFI), volksuniversiteiten (VHS) en bij- en nascholingsinstituten van de handelskamers (WIFI) - worden ingewisseld, meestal ook slechts voor bepaalde cursussen, bijvoorbeeld vreemde talen- of informaticacursussen. In enkele deelstaten, respectievelijk bij enkele werknemerskamers is een combinatie met gereduceerde deelnemersbijdragen of andere subsidiemiddelen mogelijk.

\section{Communicatie en begeleiding}

De werknemerskamers bieden de mogelijkheid van scholingsadvies aan.

\section{Financiering}

De vouchers worden betaald uit de bijdragen van de leden.

\section{Resultaat}

De totale omvang is waarschijnlijk sterk beperkt, want het gebruik ligt in de lagere eencijferige percentages: in Wenen heeft bijvoorbeeld slechts $2 \%$ van de rechthebbenden de voucher gebruikt.

\subsubsection{Geneefs scholingsvouchermodel (Zwitserland) ${ }^{28}$}

\section{Beschrijuing}

In Zwitserland is bij- en nascholing voornamelijk privé georganiseerd en gefinancierd; slechts een klein deel wordt gerealiseerd door openbare aanbieders. Omdat bij een pure marktoplossing echter lacunes worden geconstateerd, wordt naast de ondersteuning door aanbieders van bij- en nascholing de afgelopen tijd steeds meer gesproken over vraaggerichte instrumenten zoals scholingsvouchers en belastingaftrek. Sinds 200I worden bij- en nascholingsactiviteiten in Genève gestimuleerd met scholingsvouchers (chèques annuels de formation $(\mathrm{CAF})$ ). Er worden vouchers van maximaal CHF 750 (circa $€ 550$ ) per persoon per jaar beschikbaar gesteld in hoogstens drie opeenvolgende jaren. De hoogte van de daadwerkelijk verstrekte tegemoetkoming is afgestemd op het inkomen van de aanvrager.

28. EVD (2009), Bericht des EVD über eine neue Weiterbildungs-politik des Bundes, Bern: Eidgenössisches Volkswirtschaftsdepartement in Zusammenarbeit mit dem Eidgenössischen Departement des Innern (EDI); (CEPP) (2006), Evaluation du Chèque Annuel de Formation sur Mandat du Conseil d'Etat: Version Complète, Geneve: Commission externe d'évaluation des politiques publiques. 


\section{Uitvoering en beheer}

Met de vouchers probeert men vooral vrouwen, deeltijdwerkers en laagopgeleiden te bereiken omdat hun deelname in bij- en nascholing achterblijft. Beroeps(her)intreders behoren ook tot de doelgroep, voor zover de kosten voor de beoogde kwalificatieactiviteiten niet door het arbeidsbureau worden vergoed. Het bestrijden van de werkloosheid in de regio is ook een doel waaraan de voucher kan bijdragen. De vouchers kunnen worden ingewisseld voor volledige of gedeeltelijke financiering van cursussen ter verkrijging van beroepskwalificaties, beroepsmatige bij- of nascholing en/of omscholing. De voor subsidiëring in aanmerking komende cursussen moeten formeel erkend zijn en minstens 40 lesuren omvatten. Een lijst van meer dan 800 geschikte cursussen en ongeveer 70 aanbieders is op internet te raadplegen. Daar kan de aanvrager een passende bij- of nascholingsactiviteit kiezen, contact opnemen met de aanbieder en zich inschrijven.

\section{Resultaat}

Uit een evaluatie van de jaren $200 \mathrm{t} / \mathrm{m} 2004$ blijkt dat in de verslagperiode bijna 6.00o personen vouchers hebben aangevraagd.

\subsubsection{Voucherexperiment (Zwitserland) ${ }^{29}$}

\section{Beschrijving}

Om het effect van openbare financiering van bij- en nascholing door middel van scholingsvouchers te onderzoeken, is in 2006 door de federale dienst voor de beroepsopleiding en technologie (BBT) opdracht gegeven voor een pilotproject. Daarbij werden bij- en nascholingsvouchers met verschillende waardes (CHF 200, 750, I.500) (€ I45, 550, I.IO0) verstrekt aan meer dan 2.400 willekeurig gekozen personen, die deze vrij konden besteden aan bij- en nascholingsactiviteiten. Hun leergedrag werd vergeleken met dat van circa Io.000 personen die geen voucher kregen.

\section{Uitvoering en beheer}

Het moest gaan om individuele bij- of nascholing, d.w.z. bedrijfsscholing was uitgesloten.

\section{Communicatie en begeleiding}

De mogelijkheid van gratis advies was bij de helft van de vouchers gegeven, in de andere gevallen niet.

29. Wolter, S., en D. Messer (2009), Weiterbildung und Bildungsgutscheine: Resultate aus einem experimentellen Feldversuch, Schweiz: Forschungsstelle für Bildungsökonomie an der Universität Bern in Zusammenarbeit mit dem Bundesamt für Statistik; EVD (2009), Bericht des EVD über eine neue Weiterbildungs-politik des Bundes, Bern: Eidgenössisches Volkswirtschaftsdepartement in Zusammenarbeit mit dem Eidgenössischen Departement des Innern (EDI). 


\section{Resultaten}

Van de 2.437 vouchers die in het kader van dit experiment zijn uitgereikt, werd I8,4\% daadwerkelijk gebruikt voor het volgen van een scholingsactiviteit. Echter, nog eens $22 \%$ van de voucherontvangers volgde ook een scholingsactiviteit, maar leverde daarvoor de voucher niet in. Deels omdat de voucher te laat werd ontvangen (de cursus was al betaald) en deels omdat de werkgever de scholing betaalde. In totaal lag het deelnamepercentage aan bij- en nascholing van de experimentele groep rond de $40 \%$ en dat van de controlegroep op $34 \%$. Het aantal ingewisselde vouchers nam ook toe naarmate de nominale waarde van de voucher hoger was: van de vouchers van CHF 200 (€ I45) is 7\% ingewisseld, terwijl $22 \%$ van de vouchers van CHF I.500 (€ I.IOO) is ingewisseld. Het deadweight loss ${ }^{30}$ was aanzienlijk: twee derde van de personen met een opleiding na de leerplichtige leeftijd heeft een voucher ingewisseld voor bij- of nascholing, waaraan hij of zij ook zonder een voucher zou hebben deelgenomen. Bij universitair opgeleiden bedroeg het deadweight loss bijna 90\%. ${ }^{3 \mathrm{I}}$ Typische gebruikers van de vouchers waren Zwitsers in de leeftijdsgroep van 2I tot 45 jaar, die gehuwd, kinderloos en hoog opgeleid waren. Onder de belangrijkste doelgroep, de laagopgeleiden, is amper IO\% van de gebruikers van de vouchers te vinden. De reden daarvoor is onder andere het ontbreken van een doelgroepspecifiek aanbod. Over het algemeen blijkt dat personen die eerder aan bij- of nascholing hebben deelgenomen, dit wederom doen. Echter, de vouchers werden ook ingewisseld door personen die in de voorgaande jaren 2004 en 2005 niet aan bij- of nascholing hadden deelgenomen. De uitkomsten gaven aan dat in zeer geringe mate gebruik werd gemakkt van advies, waaruit de onderzoekers concludeerden dat advies zelf van beperkt belang is voor het succes van een vouchermodel.

\subsubsection{Samenvatting}

De vijftien pilotprojecten die in deze paragraaf uitgebreid in de 'spotlights' zijn gezet zijn zeer divers, maar er is wel een aantal gemene delers te bespeuren. Om met de gemene delers te beginnen: de budgetten zijn vaak niet bestemd voor iedereen, zoals wel het geval was bij de meeste bedrijfsinitiatieven, maar exclusief beschikbaar voor één of enkele doelgroepen. Bij leerbudgetten die aan een breder publiek werden aangeboden was het leerbudget voor een bepaalde doelgroep vaak hoger dan voor personen buiten die doelgroep. Laagopgeleiden, 45-plussers, herintreders, werklozen, mensen werkzaam bij kleine bedrijven of startende ondernemers zijn in de pilotprojecten vaak als doelgroep aangemerkt.

30. Het deadweight loss geeft aan hoeveel subsidie naar partijen gaat, die ook zonder de subsidie hadden geïnvesteerd in scholing. In geval van deadweight loss betaalt de overheid dus voor scholing die daarvoor of normaal gesproken toch wel gevolgd werd, maar dan betaald door werknemers en werkgevers zelf.

3I. Dit bleek uit het feit dat deze personen aangaven het besluit tot het volgen van de scholingsactiviteit al hadden genomen of al met de scholing bezig waren op het moment dat ze de voucher aanvroegen. (EVD 2009, p. 49). 
Wat betreft de variëteit, die zit hem onder andere in de hoogte van het bedrag, de termijn en het advies: leerbudgetten die binnen een jaar besteed moeten worden, variëren van $€ 50$ tot $€ \mathrm{I}$.O०O, terwijl dit bij de meerjarige budgetten op kan lopen tot $€ 2.640$ te besteden binnen een termijn van zes jaar. Daarnaast gaat aan de toekenning van diverse budgetten een (soms verplicht) adviesgesprek vooraf.

Verder blijken de Nederlandse initiatieven enkele elementen met elkaar gemeen te hebben ten opzichte van de buitenlandse initiatieven. Zo zijn de Nederlandse pilotprojecten (op één na) door de bedrijfssector georganiseerd, terwijl de buitenlandse pilots georganiseerd worden door de regio (of deelstaat). Daarnaast kenmerken de Nederlandse leerbudgetten zich door een wat vrijere/bredere keuzemogelijkheid qua cursusonderwerpen, terwijl de buitenlandse initiatieven meer gericht zijn op het verbeteren of behalen van (erkende) beroepskwalificaties. Verder is de werkgever in de Nederlandse initiatieven meer betrokken in het keuzeproces dan in het buitenland het geval is. Tot slot vergoeden de budgetten in de Nederlandse pilots de volledige kosten tot het maximale budget is bereikt, terwijl men in het buitenland vaak slechts een bepaald percentage van de gemaakte opleidingskosten vergoed tot een maximum bedrag.

Het is niet eenvoudig om, op basis van de beschikbare data, een goed oordeel te vellen over de behaalde resultaten van de verschillende projecten. Enerzijds heeft dit te maken met ontbrekend cijfermateriaal over het gebruik van de vouchers, cheques e.d. Anderzijds is de informatie die over de verschillende projecten beschikbaar is moeilijk onderling vergelijkbaar. Zo is bij diverse initiatieven een beperkt aantal cheques beschikbaar en heeft het deelnamepercentage betrekking op het aandeel van de beschikbare cheques dat besteed is. Bij andere projecten is wel bekend hoeveel vouchers, cheques, e.d. er verstrekt zijn, maar niet hoe deze aantallen zich verhouden tot de omvang van de doelgroep. 


\section{Lessen uit de theorie en de pilot- projecten: Leerpunten voor de Ontwikkelingscheque}

Op basis van de theoretische noties en praktijkvoorbeelden die in het vorige hoofdstuk zijn besproken, zullen in dit hoofdstuk leerpunten worden geformuleerd, die als input dienen voor hoofdstuk 4, waarin een uitvoeringsmodel voor de Ontwikkelingscheque wordt gepresenteerd. Dit hoofdstuk opent met een uitleg over de manier waarop de leerpunten tot stand gekomen zijn (paragraaf 3.I) gevolgd door vier paragrafen waarin de leerpunten gegroepeerd per onderwerp aan bod komen: beschrijving (paragraaf 3.2), uitvoering en beheer (paragraaf 3.3), communicatie en begeleiding (paragraaf 3.4) en tot slot financiering (paragraaf 3.5).

\subsection{Het proces: hoe leerpunten te destilleren uit de praktijk}

Wat kunnen al deze voorbeelden uit het vorige hoofdstuk waarin individuen de beschikking krijgen over eigen middelen om leeractiviteiten mee te bekostigen ons leren met betrekking tot de ontwikkeling van een Ontwikkelingscheque? In potentie veel, echter, een aantal zaken beperkt de leerpotentie van de beschreven voorbeelden.

Een voor de hand liggende werkwijze zou zijn om van de voorbeelden die succesvol zijn geweest de bepalende elementen over te nemen en de elementen van de voorbeelden die niet zo succesvol zijn geweest te vermijden. Deze werkwijze vereist zowel een eenduidige succesmaatstaf als adequate resultaatmetingen. Bij vrijwel alle projecten ontbreekt echter een heldere succesmaatstaf. Bovendien zijn bij de meeste projecten de resultaten niet of slechts gebrekkig gemeten.

Een derde complicerende factor is dat de verschillende vormen van individuele leerbudgetten zich richten op heel verschillende doelgroepen. Zo is het employabilitybudget bij ING (zie paragraaf 2.2.2) gericht op het stimuleren van de ontwikkeling van de eigen werknemers, die over het algemeen middelbaar- tot hoogopgeleid zijn, terwijl er bij de pilot in Vlaanderen (zie paragraaf 2.3.IO) vouchers werden uitgedeeld aan laagopgeleiden, werklozen of mensen die werkloos dreigden te worden. Wanneer zowel hoog- als laagopgeleiden van eenzelfde regeling gebruik mogen maken, blijkt 
dat het individueel leerbudget meer gebruikt wordt door de hoger- dan door de laagopgeleiden. Daardoor is er meestal sprake van een aanzienlijk deadweight loss. Dit verklaart ook waarom sommige leerpunten elkaar lijken tegen te spreken. Daarom zal voor zover dat mogelijk is bij de leerpunten de betreffende doelgroep waar het leerpunt betrekking op heeft, vermeld worden. Doordat de mate van succes van de beschreven projecten onderling niet eenvoudig te vergelijken is, is er bij het destilleren van de leerpunten deels uitgegaan van de subjectieve succesmaatstaf die de betrokkenen bij het project hanteerden en hun inschatting van de sterke en zwakke elementen van het project. Tot slot zijn ook enkele leerpunten van experts toegevoegd die betrekking hebben op andere projecten dan die zijn besproken in het vorige hoofdstuk. Deze leerpunten zijn herkenbaar aan een asterix $\left(^{*}\right)$.

We zullen de leerpunten van ons verkennend onderzoek presenteren volgens de onderstaande structuur:

- Beschrijving:

naam, bezit, bedrag, geldigheidsduur

- Uitvoering en beheer:

doelgroep, bestedingsdoel/-vrijheid, wijze van aanvragen

- Communicatie en begeleiding: communicatie, begeleiding (voor wie, door wie)

- Financiering:

wie (overheid, sociale partners, bedrijf, individu) levert welke bijdrage

\subsection{Beschrijving}

\section{Naam}

De theorie van het labeling effect laat zien, dat door een budget een bepaalde naam mee te geven, de ontvanger eerder geneigd zal zijn het bedrag ook daadwerkelijk aan het doel dat in de naam beschreven wordt, uit te geven. Het is dus van belang om het bestedingsdoel van de cheque expliciet in de naam op te nemen. Zo mag verwacht worden dat de naam "Ontwikkelingscheque" bevordert dat mensen goed nadenken over de trainingen, e.d. die belangrijk zouden kunnen zijn voor hun eigen ontwikkeling.

\section{Bezit}

De endowment theorie leert ons dat het raadzaam is om werknemers een Ontwikkelingscheque daadwerkelijk in hun bezit te geven. Het bezit van een waardecheque wordt immers hoger aangeslagen dan een recht dat men niet daadwerkelijk in handen heeft.

\section{Bedrag}

- De hoogte van het bedrag en de bestedingstermijn varieert bij de in hoofdstuk 2 beschreven projecten van $€ 50$ te besteden binnen een jaar tot $€ 2.640$ te 
besteden binnen zes jaar. Een te klein budget leidt niet tot een toename van de scholingsparticipatie. Echter, naarmate het bedrag hoger wordt, neemt ook de kans op deadweight loss toe.

- Het bedrag van de Ontwikkelingscheque moet dusdanig hoog zijn, dat een aanzienlijk deel van de gemaakte kosten gedekt kunnen worden. Bij een beperkt overheidsbudget is het beter een cheque van voldoende omvang aan een kleine groep ter beschikking te stellen dan iedereen een cheque te geven met een relatief klein bedrag.

\section{Geldigheidsduur}

- Volgens de endowment theorie is het zinvol om de mogelijkheid in te bouwen dat werknemers de Ontwikkelingscheque op een bepaald moment kunnen verliezen door de geldigheidsduur te beperken. Dit zorgt ervoor dat werknemers de Ontwikkelingscheque minder vaak ongebruikt laten liggen, omdat dit als een gevoelig verlies van een bezit zal worden ervaren. Ook in de communicatie rond de Ontwikkelingscheque kan het inspelen op een mogelijk verlies van bezit worden ingezet als motivator om de cheque te gebruiken.

- Ook uit diverse projecten valt te leren dat het beperken van de bestedingstermijn van het individueel leerbudget aan te raden is, zodat werknemers op een bepaald moment gedwongen worden om na te denken over de besteding ervan, maar communiceer wel tijdig dat het einde van de bestedingstermijn nadert.

- De bestedingstermijn van de cheque moet langer zijn naarmate het bedrag van het individueel leerbudget hoger is, omdat het tijd kost voor werknemers om uit te zoeken wat ze precies willen. Zeker bij hogere bedragen wil men deze 'goed' besteden en gaat men liever niet over één nacht ijs.*

\subsection{Uitvoering en beheer}

\section{Doelgroep}

- Stel het individueel leerbudget voor iedereen beschikbaar, want iedereen heeft baat bij ontwikkeling. Deze insteek wordt doorgaans gehanteerd bij leerbudgetten die binnen één bedrijf worden uitgegeven, al beperkt men de uitgifte tot werknemers die onder de bedrijfs-cao vallen en in enkele gevallen tot degenen met een vast contract.

- Stel het individueel leerbudget beschikbaar voor degenen die er het meest baat bij hebben en zonder een dergelijk budget waarschijnlijk geen leeractiviteiten ontplooien. Meestal betreft dit laagopgeleiden. Deze insteek is terug te zien in de experimentele initiatieven en initiatieven vanuit de overheid en de sociale partners. 


\section{Bestedingsdoel/vrijheid}

- Laat de werknemer vrij in zijn of haar keuze voor de leeractiviteit, maar laat de keuze wel schriftelijk of mondeling motiveren als onderdeel van de aanvraagprocedure.

- Neem ook stages en loopbaanadviestrajecten op als mogelijke bestedingsdoelen van het individueel leerbudget. Door middel van een stage kunnen werknemers een nieuwe functie eerst uitproberen alvorens ze starten met de opleiding die voor deze nieuwe functie nodig is. Loopbaanadviestrajecten kunnen helpen om een nieuw perspectief te bieden en zo een opstap vormen naar het volgen van een leeractiviteit.*

- Wanneer werknemers het individueel leerbudget volledig vrij kunnen besteden (dus ook zonder dat er een relatie is met hun werk) kan dit stimulerend werken op de zin om weer te gaan leren.

- Zorg dat bij- en nascholing dicht bij de werkplek kan plaatsvinden (met inachtneming van de vereiste afbakening ten opzichte van functiespecifieke bij- en nascholing, die door de werkgever moet worden betaald). Diverse ervaringen ondersteunen het idee dat bij- en nascholing in de buurt van de werkplek tot een positievere beeldvorming leidt over het belang van leren, op voorwaarde dat men ervaart dat de scholing het werk makkelijker maakt en/of het werk er beter door wordt.

- Er zou een kwaliteitsborging moeten plaatsvinden, om te garanderen dat er geen slechte aanbieders op de markt actief zijn, die de validiteit van het hele systeem zouden kunnen ondermijnen.

\section{Wijze van aanvragen}

- Om de administratieve lasten laag te houden is een digitale volledig geautomatiseerde aanvraagprocedure waarbij de werknemer via de computer de hele aanvraag zelf regelt, aan te bevelen.

- Leg de gemaakte afspraken over de te volgen leeractiviteit (wat, wanneer, waar, etc.) schriftelijk vast en laat dit door de betrokken partijen ondertekenen. Dit zal de betrokkenheid van de partijen bij de leeractiviteit vergroten.

- Een model waarin de leidinggevende/werkgever goedkeuring moet geven aan het bestedingsdoel van het individueel leerbudget ${ }^{32}$ is wenselijk, ook uit het oogpunt van het op gang brengen van de dialoog tussen werknemer en werkgever over de loopbaanontwikkeling van de medewerker en het stimuleren van de betrokkenheid van de werkgever bij het leerbudget. Wanneer dit, bijvoorbeeld vanwege de administratieve belasting niet wenselijk is, dan is een uitgebreid, vooraf goedgekeurd aanbod van opleidingen, e.d. waaruit de werknemer vrij zijn of haar keuze kan maken een goed alternatief.

- Houd, zeker bij laagopgeleiden, de aanvraagprocedure zo eenvoudig mogelijk en werk bij voorkeur met één aanspreekpunt/contactpersoon voor de hele aanvraagprocedure. Tegelijkertijd moet misbruik worden voorkomen. Elke als

32. In de voorbeelden worden diverse namen (leerbon, employabilitybudget, ontdekcheque) gebruikt. 
gecompliceerd of omslachtig ervaren aanvraagprocedure zal het gebruik ervan door laagopgeleiden verminderen.

- Laat werknemers niet eerst zelf de kosten betalen om deze via een declaratie later weer terug te krijgen, maar geef ze een cheque die ze direct als betaalmiddel kunnen gebruiken. Immers, mensen die het geld niet hebben om de kosten voor te schieten, zullen dit als een drempel ervaren om aan een leeractiviteit deel te nemen.*

- Koppel het in aanmerking komen voor het individueel leerbudget aan een Persoon Ontwikkelingsplan (POP) of het volgen van een workshop gericht op de toekomstige loopbaan. Op die manier is het budget geen losstaand instrument, maar maakt het deel uit van een groter geheel.

\subsection{Communicatie en begeleiding}

\section{Communicatie}

- Het individueel leerbudget moet veelvuldig, herhaaldelijk en via diverse kanalen (internet, mailings, mededelingen tijdens werkoverleg, functioneringsgesprekken, etc.) onder de aandacht worden gebracht. De juiste kanalen verschillen per doelgroep, maar een persoonlijke benadering heeft de voorkeur, vooral bij laagopgeleiden.

- Wanneer een O\&O-fonds een individueel leerbudget verstrekt, is het zinvol dat O\&O-fondsen de bedrijven bezoeken zodat werkgever en werknemers goed worden geïnformeerd. In het eerste bezoek zal men vooral informatie moeten geven over het leerbudget en in een tweede bezoek zal men vragen moeten beantwoorden.

\section{Begeleiding}

- Reserveer een deel van de voor het individueel leerbudget beschikbare middelen voor de begeleiding van de werknemers bij het maken van een keuze uit het soms overweldigende aanbod van leeractiviteiten.

- Zorg dat leidinggevenden en het management goed op de hoogte zijn van het individueel leerbudget en er positief tegenover staan. Zo kunnen zij de vragen van hun werknemers beantwoorden, hen begeleiden en het gebruik van het budget stimuleren.

- Ondersteuning van de werkgevers is belangrijk, met name als deze ook bij de financiering betrokken zijn. Aan hen moet duidelijk worden gemaakt wat voor henzelf de meerwaarde is van ondersteuning van het stimuleren van de ontwikkeling van de doelgroep.

- Zet adviseurs van de O\&O-fondsen in voor het begeleiden van werknemers en bedrijven in het keuze- en aanvraagproces.

- Het inwinnen van advies is weliswaar een belangrijk punt, maar mag niet als een barrière worden gezien (vooral bij laagopgeleiden speelt dit risico). Naast het individuele advies is het ook belangrijk dat de eigen peergroup een acti- 
verende en motiverende rol speelt. Hierbij zou de ondernemingsraad ook een aanjagende functie kunnen vervullen.

- Soms volgen werknemers geen leeractiviteit die gericht is op een andere functie, terwijl ze dit wel zouden willen, omdat ze bang zijn daarmee het signaal af te geven dat zij de huidige werkgever willen verlaten. Wanneer weerstand tegen een leeractiviteit wordt opgemerkt, dient de begeleider door te vragen om te achterhalen of dergelijke redenen een rol spelen.

\subsection{Financiering}

\section{Tijdsinvestering door de werknemer}

- Wanneer werknemers de leeractiviteiten onder werktijd kunnen volgen, is de bereidheid om een op het werk gerichte leeractiviteit te ondernemen waarschijnlijk groter. De planning van de leeractiviteit dient dan wel in goed overleg met de direct leidinggevende plaats te vinden vanwege de afwezigheid van de werknemer.

- Wanneer werknemers de leeractiviteit in eigen tijd volgen, kan de bereidheid van werknemers om een leeractiviteit te volgen lager zijn. Degenen die de activiteit in eigen tijd volgen zijn echter waarschijnlijk gemotiveerder, wat de kans op het succesvol afronden van de activiteit vergroot. Ook zal de bereidheid van werkgevers om aan de leeractiviteit mee te betalen groter zijn, als de verletkosten niet voor hun rekening komen. 


\section{Uitvoeringsmodel Ontwikkelingscheque}

De praktijk en de theorie uit hoofdstuk 2 en de daaruit volgende leerpunten uit hoofdstuk 3 vormen de input voor enkele uitvoeringsmodellen voor de Ontwikkelingscheque. Paragraaf 4.I start met een beschrijving van de contouren van het hier voorgestelde uitvoeringsmodel. In paragraaf 4.2 wordt dit model uitgewerkt in een meer specifiek model voor werknemers zonder startkwalificatie. Paragraaf 4.3 geeft een indicatie van de mogelijke kosten van de invoering van een Ontwikkelingscheque, wanneer die beschikbaar zou komen voor alle werkenden, of alleen de laagopgeleiden enlof 50+'ers. Tot slot wordt in paragraaf 4.4 aangegeven welke eerste stappen gezet zouden kunnen worden om de Ontwikkelingscheque te realiseren.

\subsection{Het model}

De in het vorige hoofdstuk geformuleerde leerpunten vormen een belangrijke basis voor het model van een individueel leerbudget dat in dit hoofdstuk gepresenteerd zal worden. Het hier voorgestelde model van de Ontwikkelingscheque is tot stand gekomen in een aantal fases. In de eerste fase is een conceptmodel opgesteld op basis van de leerpunten vanuit eerdere projecten en de theorievorming met betrekking tot vouchers. Ook is rekening gehouden met een aantal door de projectdirectie Leren en Werken gestelde randvoorwaarden. Dit conceptmodel is vervolgens uitgebreid besproken in individuele gesprekken met dertien experts (vertegenwoordigers van werkgeversvereniging, vakbeweging, diverse Opleidings- en Ontwikkelingsfondsen, lagere overheden en onderzoekers). ${ }^{33}$ Op basis van de feedback van zowel de experts als de projectdirectie is vervolgens het definitieve voorstel voor de opzet van een Ontwikkelingscheque geformuleerd.

33. Het overzicht van de geraadpleegde experts vindt $\mathrm{u}$ in de Bijlage. 


\subsubsection{Beschrijving}

\section{Naam}

Om het endowment effect maximaal te benutten, kan het individueel leerbudget het beste de vorm krijgen van een fysieke cheque. Werknemers krijgen de cheque dan daadwerkelijk in bezit, waardoor zij eerder geneigd zullen zijn deze te gebruiken dan wanneer het om een virtueel budget zou gaan. Ook de in hoofdstuk 2 beschreven projecten die werken met een daadwerkelijke rekening, cheque, of voucher ondersteunen deze keuze.

Gelet op het doel van de cheque (het stimuleren van het jezelf ontwikkelen door het wegnemen van een financiële barrière) en waar de cheque aan besteed mag worden (zie hieronder) is het passender om te spreken van een "Ontwikkelingscheque" in plaats van een opleidingscheque. Zoals in paragraaf 2.I reeds werd aangeven mag van deze naam een goed labeling effect verwacht worden. Bovendien geeft een Ontwikkelingscheque aan dat de cheque niet alleen aan trainingen of cursussen besteed kan worden, maar ook aan andere loopbaangerichte activiteiten, zoals bijvoorbeeld EVC of loopbaancoaching. Dit labeling effect zal echter verdwijnen als gekozen wordt voor een bredere term zoals 'vitaliteitscheque'. Deze term zal eerder geassocieerd worden met het op peil houden van iemands fysieke of geestelijke gezondheid.

\section{Bedrag}

De Ontwikkelingscheque bestaat uit twee cheques die stapelbaar zijn. Beide cheques worden jaarlijks uitgekeerd en zijn elk maximaal drie jaar geldig, waardoor sparen mogelijk wordt en ook iets duurdere cursussen of trainingen kunnen worden gevolgd. De toch beperkte geldigheidsduur van de cheques kan voorkomen dat de besteding van de cheques eindeloos wordt uitgesteld, waardoor veel cheques uiteindelijk niet besteed zullen worden.

De eerste cheque van $€ 500$ wordt gefinancierd en verstrekt door de overheid. De tweede cheque van $€ 500$ wordt gefinancierd door het O\&O-fonds. Wanneer de werknemer niet onder een $\mathrm{O} \& \mathrm{O}$-fonds valt, zal de werknemer de tweede cheque van de werkgever ontvangen. De werknemer draagt bij aan de Ontwikkelingscheque door de cursus of training in eigen tijd uit te voeren. De hoogte van het bedrag en de spaarmogelijkheid is gebaseerd op het feit dat een leerbudget dat te klein is vaak niet wordt besteed, mede omdat bepaalde leeractiviteiten nogal kostbaar zijn en met een te klein budget niet binnen het bereik komen van het individu. Het totaalbedrag van $€ \mathrm{I}$.০o० per jaar valt ook binnen de range van wat in eerdere experimenten daadwerkelijk aan opleidingen werd besteed. In het bovenstaande voorstel is er voor gekozen om de hoogte van de overheidsbijdrage niet te relateren aan de hoogte van de bijdrage van het O\&O-fonds of de werkgever. In dat geval zullen immers juist de werkenden in sectoren waar de scholingsdeelname erg laag is geen goede impuls krijgen om het behulp van de Ontwikkelingscheque hun competenties verder te ontwikkelen. 


\subsubsection{Uitvoering en beheer}

\section{Waar aan te besteden?}

De Ontwikkelingscheque is te besteden aan niet-functiegerichte leeractiviteiten (trainingen, workshops, cursussen) en activiteiten die gericht zijn op de loopbaanontwikkeling (assessments, loopbaanadvies, EVC-procedures, stages, etc.). In het vervolg van dit rapport worden met de term leeractiviteiten zowel niet-functiegerichte leeractiviteiten als de activiteiten die zijn gericht op de ontwikkeling van de loopbaan bedoeld. Onder niet-functiegerichte leeractiviteiten worden leeractiviteiten verstaan die niet gericht zijn op of nodig zijn voor de huidige functie. De werkgever wordt namelijk verantwoordelijk gehouden voor het financieren van functiegerichte leeractiviteiten. ${ }^{34}$ Er worden zo min mogelijk beperkingen aan de bestedingsruimte van de Ontwikkelingscheque gesteld, omdat de ervaringen met eerdere individuele leerbudgetten laten zien dat mensen zich eerder aan een leeractiviteit zullen wagen die ze zelf hebben mogen kiezen en waar hun interesse naar uitgaat. De activiteiten dienen te worden ingekocht bij gecertificeerde aanbieders om zo een bepaalde kwaliteit van de activiteiten te waarborgen. ${ }^{35}$ Ook dienen de gevolgde leeractiviteiten bij voorkeur te leiden tot een kwalificatie in of te passen in het te ontwikkelen $\mathrm{NLQF}^{36}$ maar dit is geen harde eis.

\section{Uitgifte}

De Ontwikkelingscheque hoeft niet te worden aangevraagd, maar wordt aan het begin van elk kalenderjaar automatisch aan de rechthebbenden verzonden. Het recht op een Ontwikkelingscheque wordt gebaseerd op de status die iemand heeft per I januari van het betreffende kalenderjaar. De Ontwikkelingscheque die wordt verstrekt door de overheid zal centraal worden uitgegeven door een reeds bestaande overheidsinstantie, bijvoorbeeld het Agentschap SZW of DUO. ${ }^{37}$ Hierdoor zal er geen tijd en geld verloren gaan met het opzetten van een nieuwe organisatie. De beide genoemde organisaties hebben ervaring met het verdelen van gelden en de administratie daarvan. Om afstemmingsproblemen te voorkomen en de O\&O- fondsen of individuele werkgevers niet op te zadelen met omvangrijke administratieve werkzaamheden, is het wenselijk dat ook de Ontwikkelingscheque die door het O\&O-fonds of de werkgever wordt gefinancierd door het Agentschap SZW of DUO wordt uitgegeven.

34. Uit de feedback van de experts is gebleken dat dit in theorie wel zo is of zo zou moeten zijn, maar dat de praktijk weerbarstiger is. Bij de uitwerking van het specifieke model voor werknemers zonder startkwalificatie wordt hiermee rekening gehouden (zie paragraaf 4.2).

35. Bepaalde leeractiviteiten die door (nog) niet-gecertificeerde aanbieders worden aangeboden, kunnen voor bepaalde groepen werknemers zeer nuttig zijn. Bij de uitwerking van het specifieke model voor werknemers zonder startkwalificatie wordt met deze praktijk rekening gehouden (zie paragraaf 4.2).

36. NLQF refereert aan het Nationaal Kwalificatie Kader. In dit kader probeert men het formele onderwijs, het non-formele onderwijs en de verder ontwikkeling van EVC samen te brengen. Bron: CINOP (20IO), Een kader dat niet knelt, 's-Hertogenbosch: CINOP.

37. Dienst Uitvoering Onderwijs is in januari 2010 ontstaan uit een fusie van de IB-Groep en CFI. 


\section{Inwisselen}

De werknemer besteedt de cheque(s) door het invullen van een (digitaal) formulier waarop wordt aangegeven welke leeractiviteit hij of zij wil volgen, waar en wanneer de activiteit plaatsvindt en wat deze kost. Ook moet de werknemer kort motiveren waarom deze leeractiviteit gewenst is. Hierbij zou bijvoorbeeld kunnen worden gerefereerd aan een POP of een vergelijkbaar loopbaaninstrument. Deze procedure is gebruikt bij eerdere individuele leerbudgetten. Doordat de procedure relatief eenvoudig is, hoeft het geen belemmering te zijn voor het gebruik van de cheque. Het verzoek om enige informatie te geven over de reden waarom een werknemer voor een bepaalde leeractiviteit kiest, dient twee doelen: enerzijds om de werknemers hun plannen concreet te laten maken, anderzijds voor de informatieverzameling over het gebruik van de cheque en voorkoming van fraude.

\section{Toetsing en controle}

Het formulier wordt ondertekend door de werknemer en één van de volgende partijen: de werkgever, het O\&O-fonds of het servicepunt Leren en Werken. Dit om er voor te zorgen dat de werknemer enige begeleiding c.q. feedback heeft gehad bij de keuze van de leeractiviteit. Het is echter aan de werknemer om te kiezen wie het formulier mede ondertekent. Hiervoor is gekozen om de werknemer alternatieven te bieden in het geval deze niet bij zijn of haar werkgever terecht wil of kan. Het formulier wordt vervolgens naar het centrale uitgiftepunt gestuurd met de factuur en de cheque(s), zodat het bedrag naar de aanbieder kan worden overgemaakt na controle door het uitgiftepunt. Indien een cheque niet volledig is besteed, ontvangt de werknemer een nieuwe cheque met het restbedrag. De toetsings- en controleprocedure wordt bewust zo eenvoudig mogelijk gehouden, omdat volgens diverse experts en eerdere pilots een zwaardere procedure drempels op zou kunnen werpen en derhalve negatief zou kunnen uitwerken op het gebruik van de cheque.

\subsubsection{Communicatie en begeleiding}

\section{Introductie}

Via allerlei mogelijke kanalen (tv- en radiospotjes, een internetpagina, social media, Ontwikkelingscheque-On-Tour bussen, bijeenkomsten bij de werkgever, bedrijfsbezoeken door O\&O-fondsen, vakbonden, e.d.) wordt de Ontwikkelingscheque op verschillende momenten veelvuldig onder de aandacht gebracht van de werknemers.

\section{Begeleiding}

Wie dat wil, kan op vrijwillige basis begeleiding krijgen in het keuzeproces. Deze begeleiding kan in eerste instantie gezocht worden bij de werkgever. Daarbij zou het midden- en kleinbedrijf gefaciliteerd moeten worden door O\&O-fondsen, brancheorganisaties, vakbonden of de servicepunten Leren en Werken. Eventueel kunnen ook andere organisaties voor de begeleiding worden ingeschakeld zoals uitzendbureaus, het UWV WERKbedrijf en de loopbaancoaches van de vakbonden. Diverse experts 
geven aan dat vrijwilligheid van de begeleiding belangrijk is, omdat het opdringen ervan of begeleiding als onderdeel van formele trajecten drempelverhogend kan werken, zeker bij bepaalde groepen zoals laagopgeleiden. In paragraaf 4.2 wordt de begeleiding voor de werknemers zonder startkwalificatie nader uitgewerkt. Verder verdient het aanbeveling om voor de begeleiding gebruik te maken van bestaande vertrouwensrelaties die de werknemer al heeft en dat de begeleiding in plaats en tijd makkelijk toegankelijk is (ruime openingstijden, lokaal, via telefoon en internet/e-mail bereikbaar). Bovendien moeten met de organisaties die de begeleiding ter hand nemen duidelijke afspraken worden gemaakt over de te leveren prestaties.

\subsection{Specifiek model voor de doelgroep werknemers zonder startkwalificatie}

Zoals in hoofdstuk I is aangegeven, adviseert de Denktank Leren en Werken om een Ontwikkelingscheque eerst te introduceren bij die groepen werknemers die momenteel het minst participeren in leeractiviteiten. Dit zijn werknemers zonder startkwalificatie, werknemers van 50 jaar en ouder en werknemers met een deeltijdbaan van maximaal 24 uur per week. Uit diverse onderzoeken is gebleken dat hoogopgeleiden meer in leeractiviteiten participeren dan laagopgeleiden..$^{38}$ Dit geldt overigens ook voor de oudere hoogopgeleiden en hoogopgeleide parttimers. Oftewel het opleidingsniveau heeft een grotere invloed op het participeren in leeractiviteiten dan de leeftijd of de omvang van de werkweek. Daarom wordt in deze paragraaf aangegeven in hoeverre het generieke model dat in paragraaf 4.I is beschreven, aangepast zou moeten worden om het geschikt te maken voor werknemers zonder startkwalificatie voor de arbeidsmarkt.

\subsubsection{Uitvoering en beheer}

\section{Doelgroep}

De doelgroep bestaat uit werknemers zonder 'startkwalificatie' voor de arbeidsmarkt, dat wil zeggen degenen die geen diploma op minimaal MBO niveau 2 hebben.

\section{Waar aan te besteden?}

Laagopgeleiden hebben vaker het idee dat ze geen loopbaanperspectief hebben dan hoogopgeleiden. Om die reden zien laagopgeleiden vaak het nut niet in van deelname aan leeractiviteiten, vooral als deze niet direct met hun huidige functie te maken hebben. Niet zelden hebben laagopgeleiden slechte ervaringen met het schoolsysteem en vervult leren hen met angst en onzekerheid. ${ }^{39}$ Daarom is het van groot belang om hen te laten ervaren dat nieuwe dingen leren ook leuk kan zijn, waardoor ze hun

38. Zie bijvoorbeeld Ministerie van Sociale Zaken en Werkgelegenheid (20I0), Trendrapport Aanbod van arbeid 2009, Den Haag.

39. Zie D. Fouarge, T. Schils en A. de Grip (2010), Prikkels voor postinitiële scholing van laagopgeleiden, s-Hertogenbosch/Amsterdam: ECBO. 
angst en onzekerheid kwijtraken. Ook hebben laagopgeleiden vaak nog de noodzaak om zich beter te kwalificeren voor hun huidige functie en de ontwikkelingen die zich daarin voordoen. Werkgevers zijn echter minder vaak geneigd om laagopgeleiden functiegerichte scholing aan te bieden. Deze combinatie van redenen maakt het gewenst om voor deze doelgroep de bestedingsvrijheid van de Ontwikkelingscheque te vergroten en ook de mogelijkheid te bieden om de cheque te besteden aan functiegerichte leeractiviteiten.

De bestedingsvrijheid voor laagopgeleide werknemers kan ook worden vergroot door hen toe te staan om een deel van de cheque te gebruiken voor het inkopen van studietijd, bijvoorbeeld in de vorm van een extra vrije dag of een premie voor het volgen van een cursus buiten werktijd. Op die manier levert de Ontwikkelingscheque ook een bijdrage aan het lager maken van de drempel 'geen tijd' die mensen ervan weerhoudt om aan leeractiviteiten deel te nemen.

Om het leren zo drempelloos mogelijk te maken is het van belang om het leren, waar dat kan op de werkvloer, maar anders dichtbij huis te laten plaatsvinden, bijvoorbeeld in het wijkcentrum. De certificeringseisen voor aanbieders zouden moeten worden verlaagd, bijvoorbeeld in slechts het hebben van een Kamer van Koophandelregistratie. ${ }^{40}$ Ook zou het leren zo praktijkgericht mogelijk moeten zijn.

\section{Inwisseling \& Toetsing en controle}

De te doorlopen stappen voor het inwisselen van de Ontwikkelingscheque(s) en de toetsing en controle is hetzelfde als in het generieke model. Er zal echter aan de betrokken partijen (werkgever, vakbonden, O\&O-fondsen, servicepunten Leren en Werken, etc.) moeten worden gevraagd extra aandacht te besteden aan deze doelgroep, aangezien laagopgeleiden waarschijnlijk meer begeleiding nodig hebben bij de besteding van de cheque, ondanks het feit dat de procedure relatief eenvoudig is. In de volgende subparagraaf wordt hier verder op ingegaan.

\subsubsection{Communicatie en begeleiding}

\section{Introductie}

Het sleutelwoord bijzowel de introductieals de begeleidingvan deOntwikkelingscheque voor deze doelgroep is "persoonlijk contact". De cheque moet bij laagopgeleiden ook onder de aandacht gebracht worden in individuele gesprekken, of in gesprekken in hun peergroup. Bij voorkeur op momenten die passen in het dagelijks werk of leven, zoals tijdens de lunch in de kantine, tijdens werkoverleg, op het vakbondsspreekuur, e.d.

40. Deze aanpak is succesvol gebruikt door de provincie Noord-Brabant bij de Leerbon (zie paragraaf 2.3.I). 


\section{Begeleiding}

Ook voor de begeleiding tijdens het keuzetraject en de procedures voor inwisseling, toetsing en controle geldt dat persoonlijk contact cruciaal is. Bij voorkeur steeds met dezelfde persoon zodat een vertrouwensband kan worden opgebouwd. En bij voorkeur met iemand die dichtbij de werknemer staat. Denk hierbij aan seniorcollega's, ondernemingsraadsleden of vakbondsleden die hiervoor worden opgeleid. Hoewel het van belang is de begeleiding op vrijwillige basis aan te bieden, omdat het verplichten hiervan contraproductief kan werken, moet er wel actief op deze doelgroep worden afgestapt. Laagopgeleiden zullen waarschijnlijk niet uit zichzelf om hulp vragen. De begeleiding zou er bijvoorbeeld als volgt uit kunnen zien:

- In een persoonlijk gesprek bespreekt een begeleider/adviseur met de werknemer een toekomstig probleem of behoefte; bijvoorbeeld dat iemand vanwege de fysieke zwaarte van zijn of haar werk niet tot aan het pensioen door kan blijven werken in dezelfde functie of sector.

- Het doen van een test via internet of met een begeleider waaruit een diagnose of advies volgt.

- In een tweede persoonlijk gesprek met een begeleider/adviseur wordt de diagnose of het advies verder besproken en omgezet in mogelijke concrete acties.

Om de leeractiviteiten in de loop van de tijd naar een hoger plan te tillen, is het van belang dat gemonitord wordt welke leeractiviteiten iemand volgt, zodat de begeleider adviezen kan geven die de ontwikkeling van iemands leeractiviteiten in een bepaalde richting sturen.

\subsection{Financiering en verwachte kosten}

Aan de invoering van de Ontwikkelingscheque hangt vanzelfsprekend een prijskaartje. Maar hoe hoog is de prijs op dat kaartje en zijn de financiële middelen daarvoor (structureel) aanwezig bij de betrokken partijen? Om die vragen te kunnen beantwoorden kijken we in deze paragraaf naar welke partijen een bijdrage zouden moeten leveren aan de Ontwikkelingscheque en hoe groot die bijdrage is.

\section{Wie financiert wat?}

De Ontwikkelingscheques worden bekostigd door zowel de overheid als het O\&O-fonds of de werkgever. Daarnaast levert de werknemer een bijdrage in natura door de leeractiviteit in eigen tijd te volgen. Eventueel kan van werknemers die al in het bezit zijn van een startkwalificatie een financiële bijdrage worden gevraagd, bovenop de eerdergenoemde bijdrage in natura.

Naast de financiering van de Ontwikkelingscheque zelf, is het van belang dat de overheid ook middelen reserveert voor enkele aanvullende faciliteiten. Ten eerste is er geld nodig voor de begeleiding van de werknemers in hun keuzeproces door diverse partijen waaronder servicepunten Leren en Werken, UWV WERKbedrijf, etc. Ten 
tweede zijn er middelen nodig om de uitgiftetaak van de Ontwikkelingscheque door bijvoorbeeld het Agentschap SZW of DUO te bekostigen.

\section{Financieringsbronnen}

De bekostiging van de Ontwikkelingscheque kan worden gezocht in een aantal bronnen. Ten eerste is er momenteel een lappendeken van allerhande regelingen die het volgen van postinitiële scholing proberen te bevorderen. ${ }^{4 \mathrm{I}}$ Door deze versnippering zien betrokkenen door de bomen het bos niet meer. Het verdient aanbeveling deze regelingen zoveel mogelijk te schrappen en de vrijgekomen middelen te gebruiken voor de bekostiging van de Ontwikkelingscheque die de overheid uitgeeft. Het is echter onduidelijk welke bedragen er vrijkomen als deze regelingen worden afgeschaft. Ook is onduidelijk in hoeverre de regelingen op korte termijn kunnen worden afgeschaft en de middelen kunnen worden vrijgemaakt voor de Ontwikkelingscheque.

Ten tweede worden werkgevers en werknemers momenteel via een aantal regelingen gestimuleerd om opleidingen te (laten) volgen via de Wet Vermindering Afdracht onderwijs (werkgevers) en de aftrekpost voor studiekosten, spaarloon en levensloopregeling (werknemers). Door het afschaffen of aanpassen van deze regelingen zouden ook middelen voor de Ontwikkelingscheque kunnen worden vrijgemaakt. ${ }^{42}$

Ten derde kan worden gedacht aan het inzetten van WW-gelden voor de Ontwikkelingscheque op basis van het preventieve effect op werkloosheid dat uit kan gaan van het stimuleren van de ontwikkeling van met name laagopgeleide werknemers. ${ }^{43}$

\section{Verwachte kosten}

In tabel 4.I staat een overzicht van de verwachte kosten van de Ontwikkelingscheque voor zowel de overheid als de O\&O-fondsen/werkgevers. De berekeningen zijn uitgevoerd voor vier verschillende scenario's. ${ }^{44}$

I. een Ontwikkelingscheque voor alle werkenden

2. een Ontwikkelingscheque voor alleen de laagopgeleiden

3. een Ontwikkelingscheque voor alleen de so+'ers

4. een Ontwikkelingscheque voor alle laagopgeleiden en so+'ers

4I. Zo bieden Opleidings- \& Ontwikkelingsfondsen en andere fondsen, de Europese commissie, de landelijke overheid en provinciale en gemeentelijke overheden gezamenlijk ruim 500 verschillende subsidies en regelingen aan voor scholingsgerelateerde activiteiten (Bron: http://www.regelingenvoorscholing.nl/ (28 februari 20II)).

42. Zie tabel $\mathrm{B}_{3}$ in de Bijlage voor een indicatie van het budgettaire beslag van deze regelingen in 2010.

43. Zie ook SER (2OII) Werk maken van baan-baanmobiliteit, Den Haag, paragraaf 5.4.3.

44. De werkenden in deeltijd worden hier buiten beschouwing gelaten omdat de omvang van de werkweek veel minder bepalend is voor de participatie in leven lang leren dan het opleidingsniveau (zie paragraaf 4.2). Met andere woorden de deeltijdwerkers zonder startkwalificatie zijn al opgenomen in de doelgroep werknemers zonder startkwalificatie en het stimuleren van de deeltijdwerkers met een startkwalificatie heeft een lagere prioriteit. 
Omdat de verwachte kosten afhankelijk zijn van het daadwerkelijk gebruik van de Ontwikkelingscheque, zijn per doelgroep telkens twee bedragen berekend: een bedrag gebaseerd op I00\% besteding van de Ontwikkelingscheques en een bedrag gebaseerd op een besteding van 50\% van de cheques. Het bestedingspercentage van $50 \%$ is enerzijds gebaseerd op het hoogst behaalde bestedingspercentage in de eerdere projecten van $45 \%$ (Individueel inzetbaarheidbudget van KPN, zie paragraaf 2.I.I). Anderzijds blijkt uit de ROA Leven lang leren enquête 2010 dat $58 \%$ van de werkenden het waarschijnlijk acht dat ze gebruik gaan maken van een door de overheid uitgegeven opleidingsvoucher, terwijl $23 \%$ zegt dat de kans daarop 50-50 is. Bij de belangrijkste doelgroep, de laagopgeleide werkenden, liggen deze percentages lager: van de werkenden met maximaal een VMBO-diploma zegt $44 \%$ een overheidscheque te zullen gaan gebruiken en $32 \%$ schat de kans in op 50-50. Hoewel deze percentages hoger zijn dan de gerealiseerde bestedingspercentages in de in hoofdstuk 2 beschreven projecten, betreft dit slechts intenties, terwijl verwacht mag worden dat het daadwerkelijk gebruik lager zal zijn. ${ }^{45}$

\section{Tabel 4.1}

Verwachte kosten Ontwikkelingscheque naar doelgroep

\begin{tabular}{|c|c|c|c|c|}
\hline & \multicolumn{2}{|c|}{$100 \%$ besteding } & \multicolumn{2}{|c|}{$50 \%$ besteding } \\
\hline & $\begin{array}{l}\text { Vereiste bijdrage } \\
\text { overheid }\end{array}$ & $\begin{array}{l}\text { Vereiste bijdrage 0\&0- } \\
\text { fondsen/werkgevers }\end{array}$ & $\begin{array}{l}\text { Vereiste bijdrage } \\
\text { overheid }\end{array}$ & $\begin{array}{l}\text { Vereiste bijdrage 0\&0- } \\
\text { fondsen/werkgevers }\end{array}$ \\
\hline $\begin{array}{l}\text { Ontwikkelingscheque voor } \\
\text { alle werkenden: }\end{array}$ & $\begin{array}{l}\text { 7.112.000 personen } x \\
€ 500= \\
€ 3.556 \mathrm{mln} .\end{array}$ & $\begin{array}{l}7.112 .000 \text { personen } x \\
€ 500= \\
€ 3.556 \mathrm{mln} .\end{array}$ & $\begin{array}{l}3.556 .000 \text { personen } x \\
€ 500= \\
€ 1.778 \mathrm{mln} .\end{array}$ & $\begin{array}{l}3.556 .000 \text { personen } x \\
€ 500= \\
€ 1.778 \mathrm{mln} .\end{array}$ \\
\hline $\begin{array}{l}\text { Ontwikkelingscheque } \\
\text { voor werkenden zonder } \\
\text { startkwalificatie: }\end{array}$ & $\begin{array}{l}1.980 .500 \text { personen } x \\
€ 500= \\
€ 990,25 \mathrm{mln} \text {. }\end{array}$ & $\begin{array}{l}1.980 .500 \text { personen } x \\
€ 500= \\
€ 990,25 \mathrm{mln} \text {. }\end{array}$ & $\begin{array}{l}990.250 \text { personen } x \\
€ 500= \\
€ 495,125 \mathrm{mln} .\end{array}$ & $\begin{array}{l}990.250 \text { personen } x \\
€ 500= \\
€ 495,125 \mathrm{mln} .\end{array}$ \\
\hline $\begin{array}{l}\text { Ontwikkelingscheque voor } \\
\text { werkenden } 50+\text { : }\end{array}$ & $\begin{array}{l}1.861 .000 \text { personen } x \\
€ 500= \\
€ 930,5 \mathrm{mln} .\end{array}$ & $\begin{array}{l}1.861 .000 \text { personen } x \\
€ 500= \\
€ 930,5 \mathrm{mln} .\end{array}$ & $\begin{array}{l}930.500 \\
\text { personen } x \\
€ 500= \\
€ 465,25 \mathrm{mln} .\end{array}$ & $\begin{array}{l}930.500 \\
\text { personen } x \\
€ 500= \\
€ 465,25 \mathrm{mln} .\end{array}$ \\
\hline $\begin{array}{l}\text { Ontwikkelingscheque } \\
\text { voor werkenden zonder } \\
\text { startkwalificatie + } \\
\text { werkenden } 50+\text { : }\end{array}$ & $\begin{array}{l}3.248 .000 * \text { personen } x \\
€ 500= \\
€ 1.624 \mathrm{mln} .\end{array}$ & $\begin{array}{l}3.248 .000 \text { personen } x \\
€ 500= \\
€ 1.624 \mathrm{mln} .\end{array}$ & $\begin{array}{l}1.624 .000 \text { personen } x \\
€ 500= \\
€ 812 \mathrm{mln} .\end{array}$ & $\begin{array}{l}1.624 .000 \text { personen } x \\
€ 500= \\
€ 812 \mathrm{mln} .\end{array}$ \\
\hline
\end{tabular}

* Het aantal werknemers in deze gecombineerde doelgroep is niet gelijk aan de optelsom van aparte doelgroepen vanwege een aanzienlijke overlap: 593.000 werkenden zonder startkwalificatie zijn namelijk 50 jaar of ouder. Het aantal personen in deze gecombineerde doelgroep is dus als volgt berekend: $1.980 .500+1.861 .000$ $-593.500=3.248 .000$.

Het aantal werknemers per doelgroep is afkomstig uit de Enquête Beroepsbevolking (EBB) 2009 van het CBS.

45. Andere motiveringen om bij de berekening van de verwachte kosten uit te gaan van het hoge bestedingspercentage van $50 \%$ zijn:

I) de veronderstelling dat het instrument succesvoller zal zijn dan de besproken cases omdat lering is getrokken uit deze ervaringen en

2) om te voorkomen dat de Ontwikkelingscheque voortijdig moet worden stopgezet wegens budgetoverschrijding wanneer de cheque inderdaad succesvoller blijkt te zijn dan zijn voorgangers. 
Tabel 4.I laat zien dat aan de Ontwikkelingscheque een stevig prijskaartje hangt. Zo is voor het beschikbaar stellen van de Ontwikkelingscheque aan alleen de werkenden zonder startkwalificatie bij een bestedingspercentage van $50 \%$ al bijna $€ 500$ miljoen per jaar nodig. Voor de overheid, maar zeker ook voor de O\&O-fondsen is een dergelijk bedrag niet op te brengen. ${ }^{46}$ Ook lagere bedragen zullen voor veel O\&O-fondsen problematisch zijn. Enkele experts hebben namelijk aangegeven, dat ongeveer 60 van de ongeveer IIo O\&O-fondsen niet de financiële middelen hebben om de laagopgeleide werknemers in hun branche jaarlijks met een aanzienlijk bedrag te steunen. Dit geldt nog sterker voor fondsen van sectoren waarin laagopgeleiden oververtegenwoordigd zijn. In deze sectoren zullen werkgevers bij voorkeur door de CAO er toe moeten worden aangezet om zelf een bijdrage aan de Ontwikkelingscheque te leveren. Verder kan er ook gedacht worden aan de oprichting van een sectoroverstijgend O\&O-fonds dat de tweede Ontwikkelingscheque namens de werkgevers/O\&O-fondsen uitgeeft.

\subsection{De eerste stap}

De vorige paragraaf heeft laten zien dat de financiële middelen vereist voor de invoering van een Ontwikkelingscheque voor de door de Denktank geformuleerde doelgroepen, zeker op dit moment niet gemakkelijk beschikbaar zullen komen. Dit is echter geen reden om de Ontwikkelingscheque vaarwel te zeggen. Wat wel nodig is, is een verdere inperking van de doelgroep. Zoals in paragraaf 4.2 werd aangegeven is het meeste rendement te behalen door het stimuleren van de ontwikkeling van laagopgeleide werknemers. Het is echter niet mogelijk om Ontwikkelingscheque(s) van voldoende omvang (een cheque van $€ 500$ door de overheid en eenzelfde cheque van $€$ soo door O\&O-fondsen/werkgevers) uit te reiken aan de bijna 2 miljoen laagopgeleide werknemers in Nederland.

Bij het verder inperken van de doelgroep is gekeken voor welke groepen laagopgeleiden loopbaangerichte leeractiviteiten het meest belangrijk zijn. Om deze meer specifieke doelgroep te bepalen is gekeken naar de werkgelegenheidsontwikkeling in de diverse bedrijfssectoren. Laagopgeleiden die werken in bedrijfssectoren waarin de werkgelegenheid afneemt, lopen een grotere kans hun baan te verliezen dan laagopgeleiden werkzaam in sectoren waar de werkgelegenheid stabiel is of groeiende. Het verdient dan ook de voorkeur om de beperkte middelen in te zetten voor een Ontwikkelingscheque voor laagopgeleide werknemers in de 'krimp'-sectoren.

46. In 2009 bedroegen de totale lasten van de 53 algemeen verbindend verklaarde O\&O fondsen tezamen $€ 57 \mathrm{I}, 3$ miljoen. $59 \%$ van deze lasten ( $€$ 337,I miljoen) was bestemd voor opleiden en ontwikkelen. Daarnaast zijn de gezamenlijke reserves van deze fondsen eind 2009 gedaald tot $€ 540,3$ miljoen. Naast deze 53 algemeen verbindend verklaarde fondsen zijn er nog 39 niet algemeen verbindend verklaarde fondsen. Bron: W. Smits e.a. (20I0), Cao-fondsen van 2009 in beeld; financiële verkenning van avv'de ideële fondsen, Den Haag: Ministerie van Sociale Zaken en Werkgelegenheid. 
Tabel 4.2

Werkenden zonder startkwalificatie naar bedrijfssector met werkgelegenheidskrimp in de periode 2005-2009

\begin{tabular}{|c|c|c|c|}
\hline Bedrijfssector & $\begin{array}{l}\text { Werkenden* } \\
\text { (in personen) }\end{array}$ & $\begin{array}{c}\text { Werkenden zonder } \\
\text { startkwalificatie } \\
(\%)\end{array}$ & $\begin{array}{l}\text { Werkenden zonder } \\
\text { startkwalificatie } \\
\text { (in personen) }\end{array}$ \\
\hline Landbouw en visserij & 171.000 & 38 & 64.980 \\
\hline Vlees- en visverwerking & 29.000 & 52 & 15.080 \\
\hline Basischemie & 33.000 & 16 & 5.280 \\
\hline Eindproducten chemie & 33.500 & 18 & 6.030 \\
\hline Kunststofverwerking & 32.500 & 39 & 12.675 \\
\hline Basismetaal & 22.500 & 29 & 6.525 \\
\hline Metaalproducten & 95.000 & 40 & 38.000 \\
\hline Hout- en bouwmaterialen & 215.500 & 52 & 112.060 \\
\hline Papier & 18.500 & 42 & 7.770 \\
\hline Grafische industrie & 75.000 & 23 & 17.250 \\
\hline Verzekeringswezen & 91.500 & 10 & 9.150 \\
\hline Totaal krimpende sectoren & 817.000 & 36 & 294.800 \\
\hline
\end{tabular}

Tabel 4.2 geeft een overzicht van de bedrijfssectoren die in de periode 2005-2009 te maken hebben gehad met een krimpende werkgelegenheid. Ook in de komende jaren zal de werkgelegenheid in deze sectoren verder teruglopen. ${ }^{47}$ Per bedrijfssector is aangegeven hoeveel personen er in deze sector werkzaam zijn, welk percentage daarvan geen startkwalificatie heeft en het aantal werknemers zonder startkwalificatie. Opvallend is dat in de bedrijfssectoren uit tabel 4.2 relatief meer laagopgeleiden werken dan het landelijk gemiddelde, namelijk $36 \%$ versus gemiddeld $24 \% .{ }^{48}$ Dit makt het verbeteren van de inzetbaarheid van deze doelgroep extra relevant en urgent.

In tabel 4.3 is aangegeven wat de verwachte overheidskosten zouden zijn van een Ontwikkelingscheque van $€ 500$ voor de laagopgeleiden in de bedrijfssectoren met werkgelegenheidskrimp. De tweede kolom geeft aan wat de regeling per bedrijfssector maximaal zal kosten als alle rechthebbenden hun cheque zouden besteden, terwijl in de derde kolom, analoog aan tabel 4.I, wordt uitgegaan van een bestedingspercentage van $50 \%$.

47. De verwachte uitbreidingsvraag tot 2014 in deze sectoren is negatief, met andere woorden er is in deze sectoren sprake van een dalende werkgelegenheid. Bron: ROA (2009), De arbeidsmarkt naar opleiding en beroep tot 2014, ROA-R-2009/5, Maastricht.

48. Bron: CBS / EBB bewerking ROA. 
Tabel 4.3

Verwachte kosten Ontwikkelingscheque per bedrijfssector met werkgelegenheidskrimp

\begin{tabular}{|c|c|c|c|}
\hline \multirow[t]{2}{*}{ Bedrijfssector } & \multirow{2}{*}{$\begin{array}{l}\text { Werkenden zonder } \\
\text { startkwalificatie } \\
\text { (in personen) }\end{array}$} & \multicolumn{2}{|c|}{ Kosten voor de overheid } \\
\hline & & $100 \%$ besteding ${ }^{*}$ & $50 \%$ besteding ${ }^{* *}$ \\
\hline Landbouw en visserij & 64.980 & $€ 32.490 .000$ & $€ 16.245 .000$ \\
\hline Vlees- en visverwerking & 15.080 & $€ 7.540 .000$ & $€ 3.770 .000$ \\
\hline Basischemie & 5.280 & $€ 2.640 .000$ & $€ 1.320 .000$ \\
\hline Eindproducten chemie & 6.030 & $€ 3.015 .000$ & $€ 1.507 .500$ \\
\hline Kunststofverwerking & 12.675 & $€ 6.337 .500$ & $€ 3.168 .750$ \\
\hline Basismetaal & 6.525 & $€ 3.262 .500$ & $€ 1.631 .250$ \\
\hline Metaalproducten & 38.000 & $€ 19.000 .000$ & $€ 9.500 .000$ \\
\hline Hout- en bouwmaterialen & 112.060 & $€ 56.030 .000$ & $€ 28.015 .000$ \\
\hline Papier & 7.770 & $€ 3.885 .000$ & $€ 1.942 .500$ \\
\hline Grafische industrie & 17.250 & $€ 8.625 .000$ & $€ 4.312 .500$ \\
\hline Verzekeringswezen & 9.150 & $€ 4.575 .000$ & $€ 2.287 .500$ \\
\hline Totaal krimpende sectoren & 294.800 & $€ 147.400 .000$ & $€ 73.700 .000$ \\
\hline \multicolumn{4}{|c|}{$\begin{array}{l}\text { * Bedragen in deze kolom zijn als volgt berekend: aantal werkenden zonder startkwalificatie } x € 500 \text {. } \\
\text { Voorbeeld “Landbouw en visserij": } 64.980 x € 500=€ 32.490 .000 .\end{array}$} \\
\hline \multirow{2}{*}{\multicolumn{4}{|c|}{$\begin{array}{l}\text { ** Bedragen in deze kolom zijn als volgt berekend: aantal werkenden zonder startkwalificatie x } € 500 \times 0,5 \text {. } \\
\text { Voorbeeld "Landbouw en visserij": } 64.980 x € 500 \times 0,5=€ 16.245 .000 \text {. }\end{array}$}} \\
\hline & & & \\
\hline \multicolumn{4}{|c|}{ Bron: CBS / EBB bewerking ROA } \\
\hline
\end{tabular}

Door de Ontwikkelingscheque ter beschikking te stellen aan de werknemers zonder startkwalificatie in de bedrijfssectoren uit tabel 4.3 wordt een groep bediend die deze extra steun goed kan gebruiken gezien de werkgelegenheidsontwikkeling in hun sector. Bovendien kunnen de sectoren die de komende jaren te kampen krijgen met personeelstekorten erbij gebaat zijn als laagopgeleiden die werkzaam zijn in krimpsectoren anticiperen op een voortzetting van hun loopbaan in een tekortsector. Tegelijkertijd biedt deze beperkte invoering van de Ontwikkelingscheque een mogelijkheid om de effectiviteit van de Ontwikkelingscheque te testen op onvoorziene kosten, voordat deze in de toekomst eventueel verder wordt uitgerold.

Van belang is om te vermelden dat in de berekening van de verwachte kosten in zowel tabel 4.I als 4.3 geen rekening is gehouden met de additionele kosten voor de begeleiding van de laagopgeleide werknemers bij het keuzeproces en de exploitatiekosten die gemoeid zijn met de uitgifte en het beheer van de Ontwikkelingscheque (zie paragraaf 4.3). Met name de kosten voor de begeleiding van de laagopgeleiden kunnen aanzienlijk zijn, omdat deze begeleiding via persoonlijk contact dient plaats te vinden. Deze begeleiding is echter van cruciaal belang om de Ontwikkelingscheque in deze doelgroep te laten slagen. 


\section{Bijlagen}

\section{Tabel BI}

Eerste inventarisatie van individuele leerbudgetten buiten Nederland

\section{Tabel B2}

Eerste inventarisatie van individuele leerbudgetten in Nederland

\section{Overzicht experts}

\section{Tabel B3}

Budgettair beslag van huidige maatregelen in 2010 

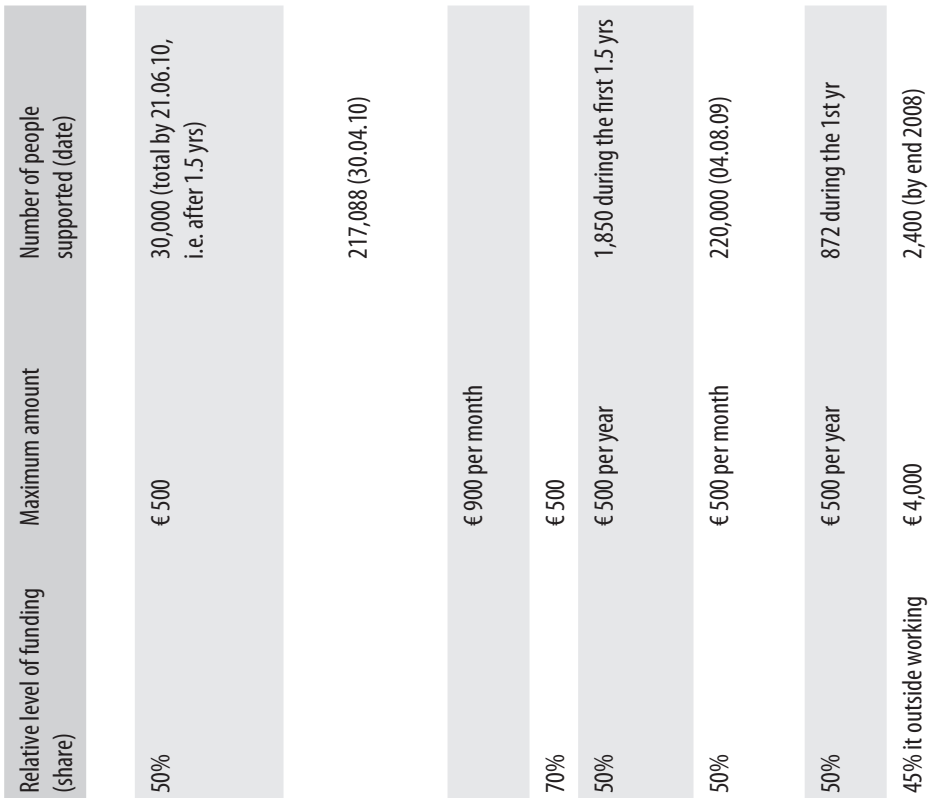

ઠे

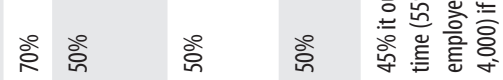
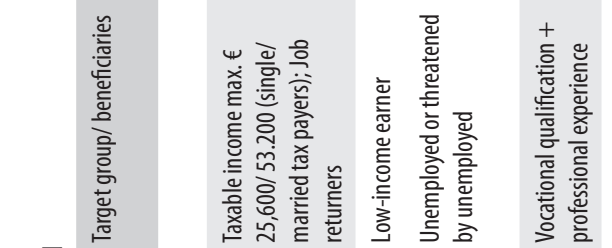

㐔 气

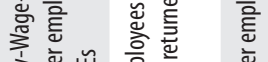
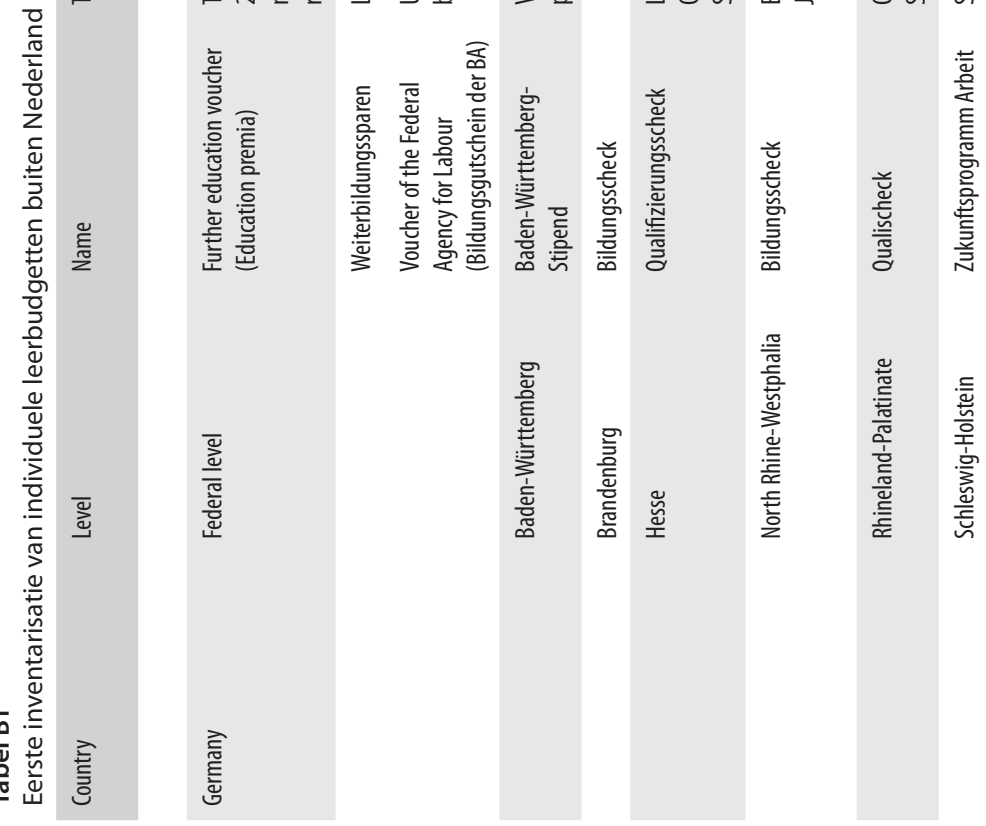

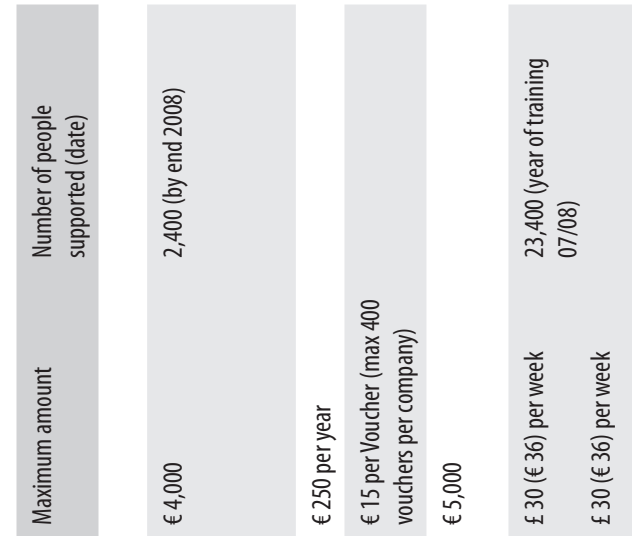

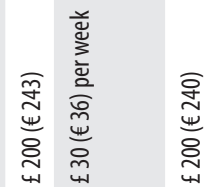

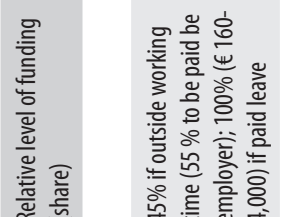

ㅇํํ ㅇํํ

ذั
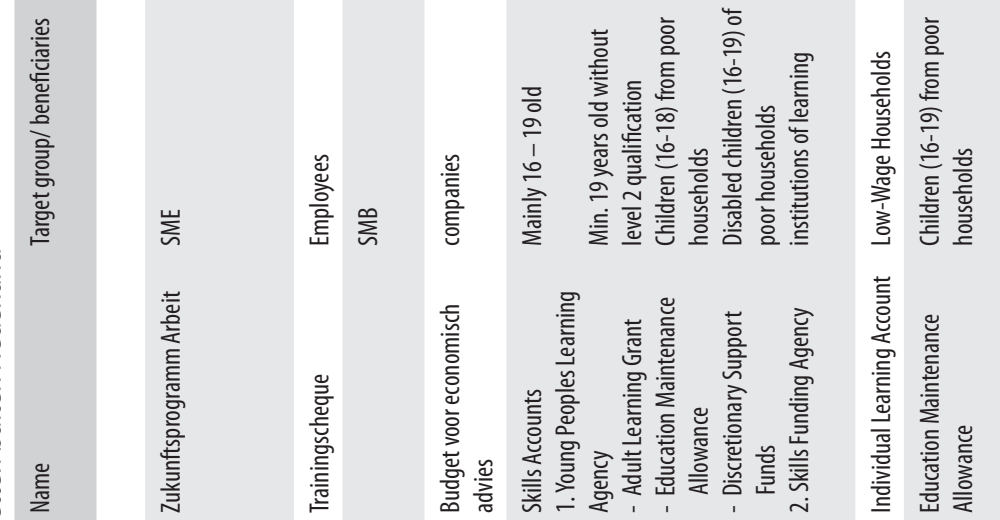

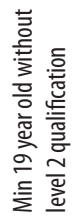
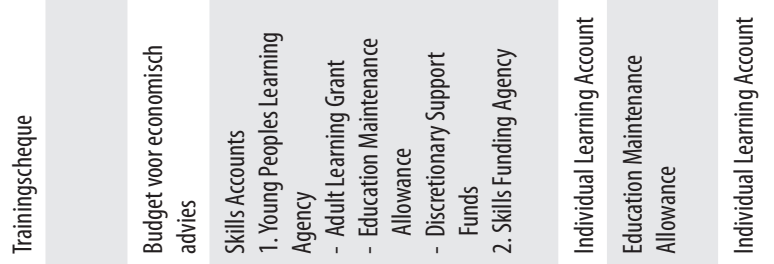

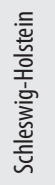

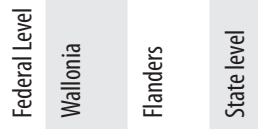

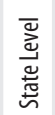

离
䒿
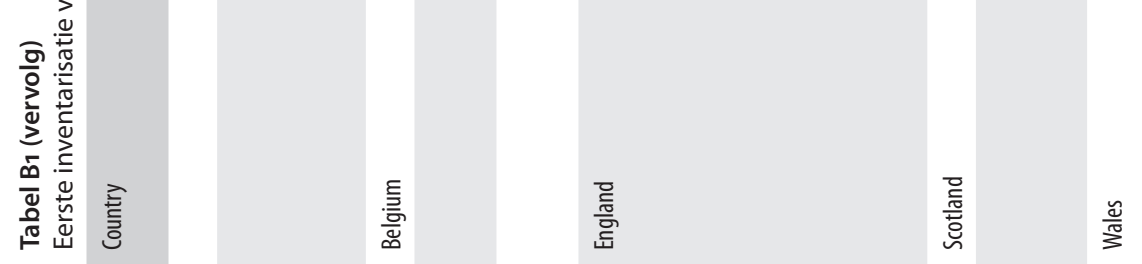

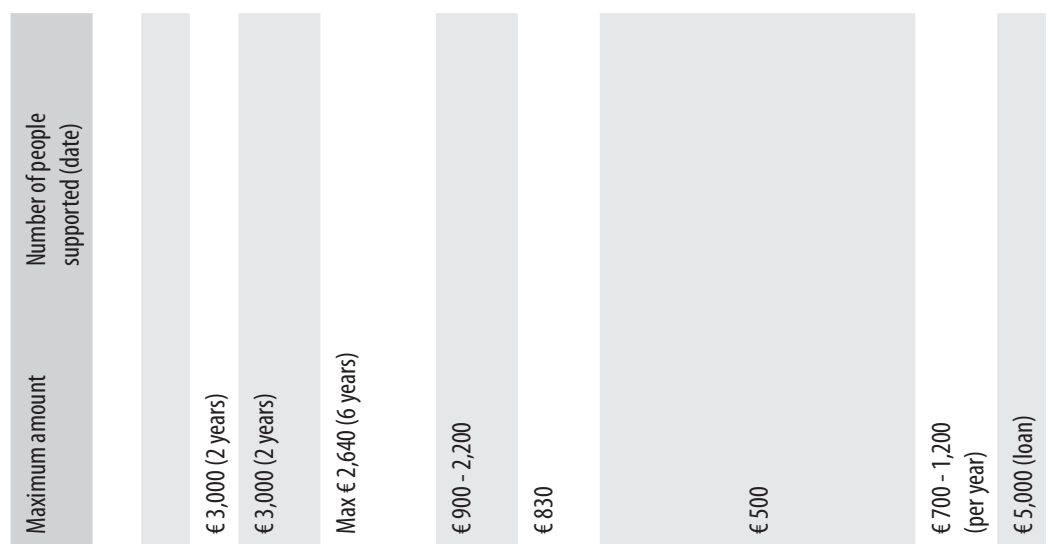

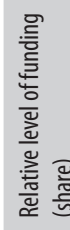

ळें

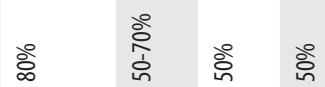

ธें

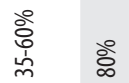
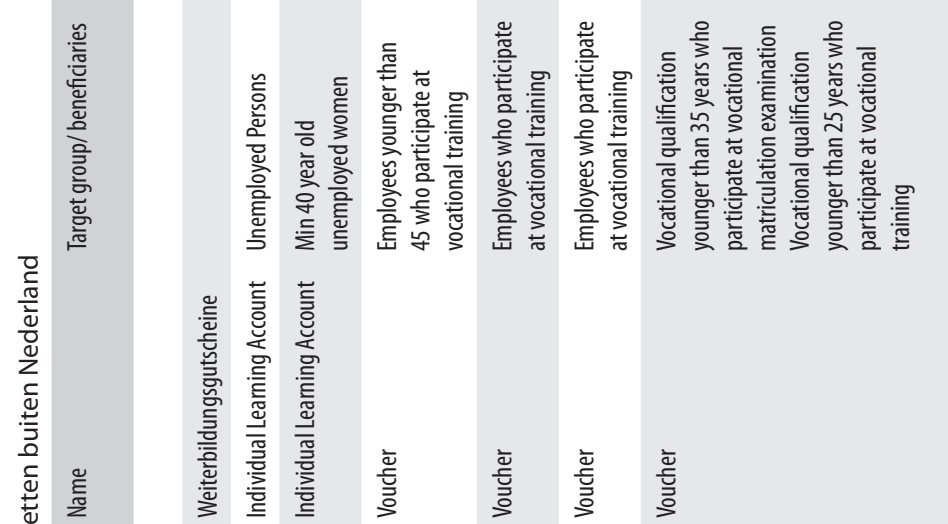

喜

咅喜咅
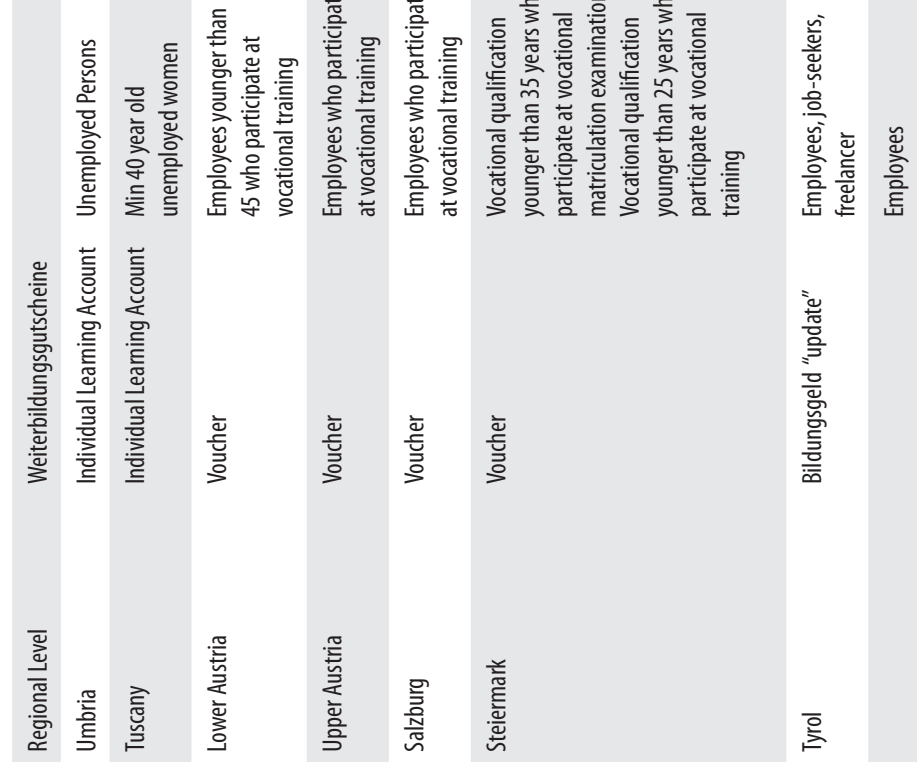

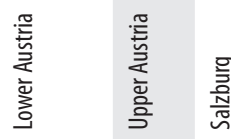

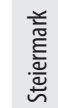

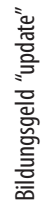

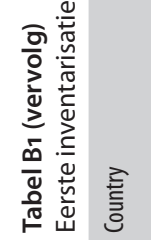

尊

曾 


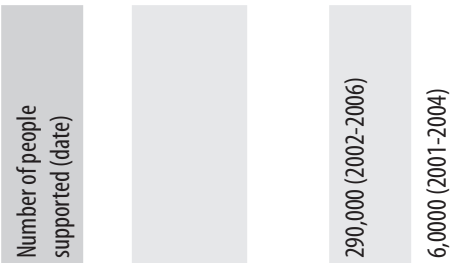

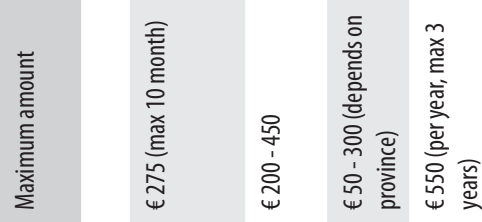
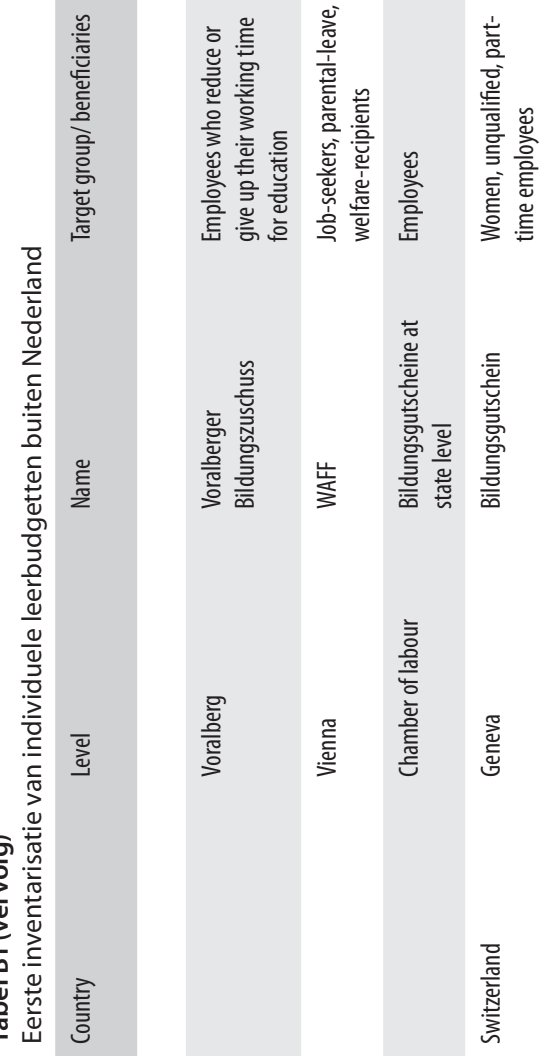


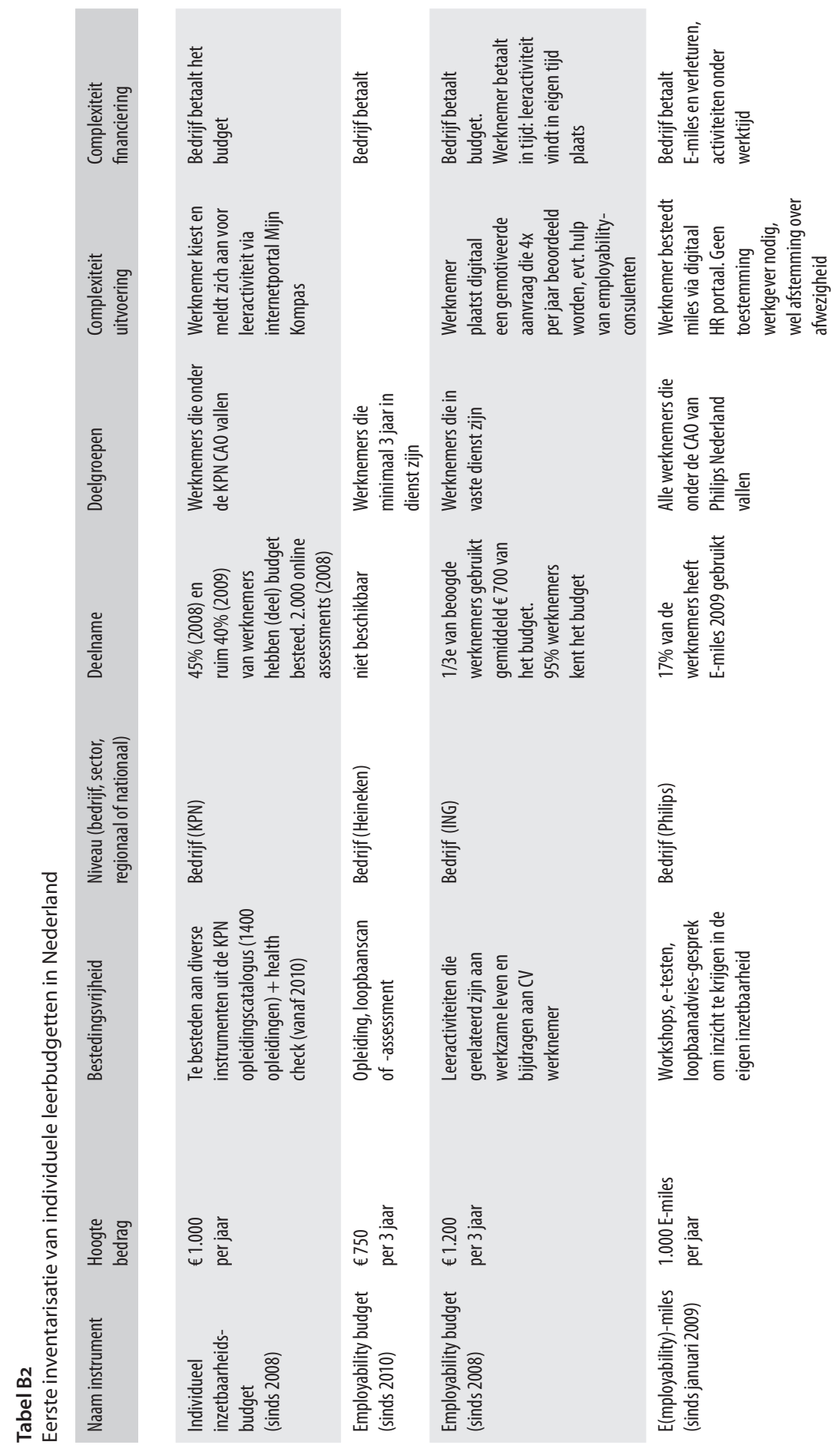



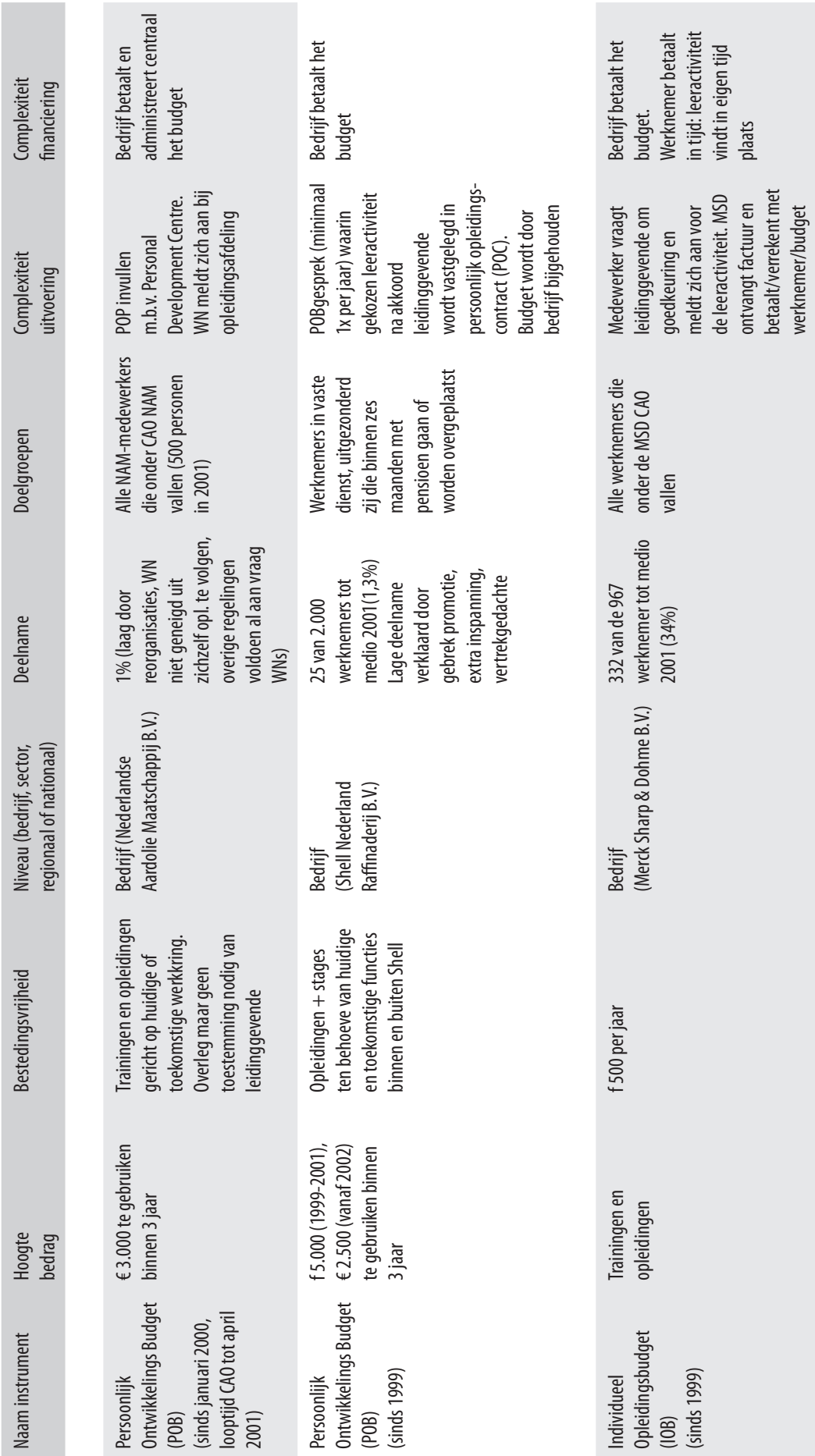

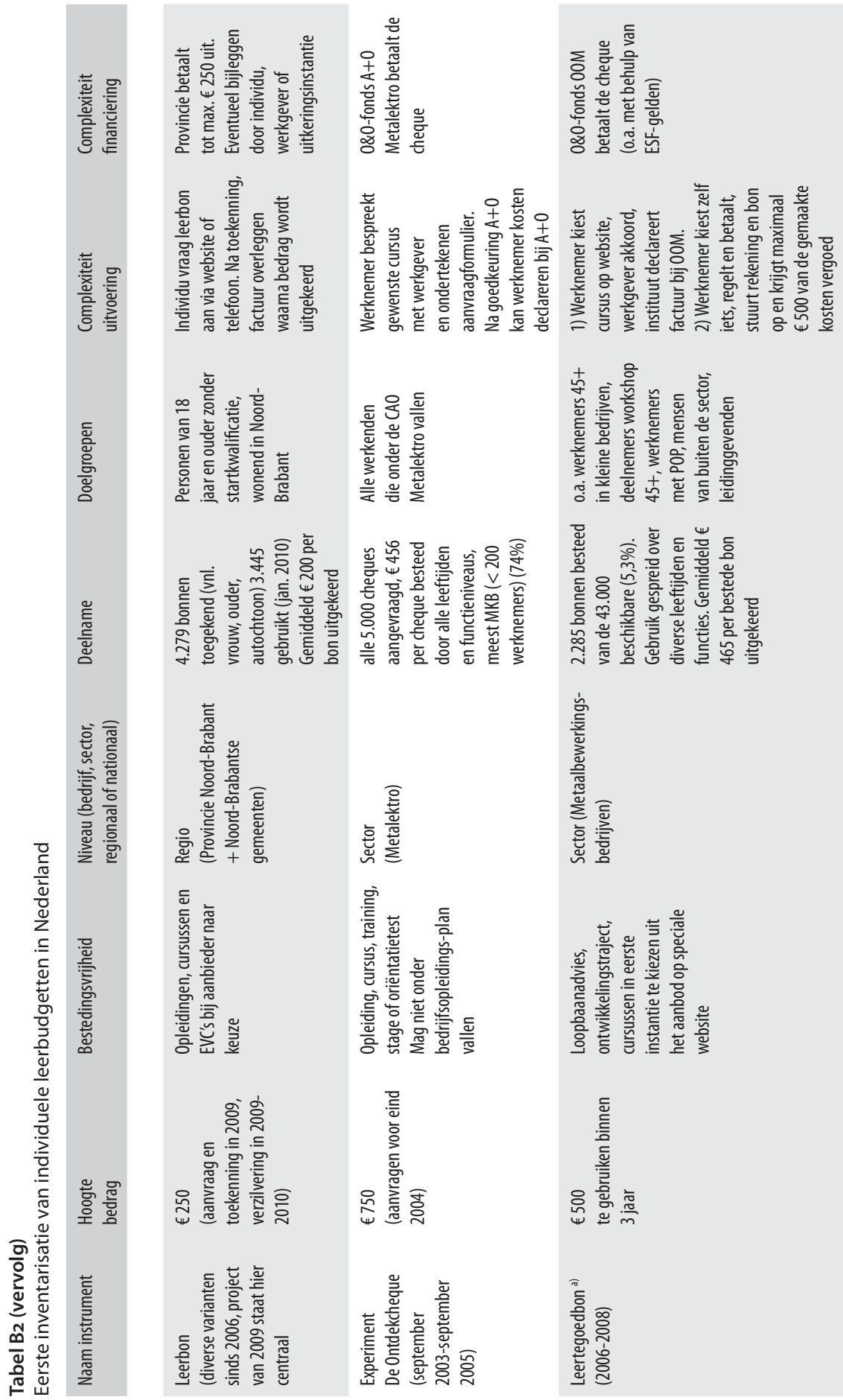


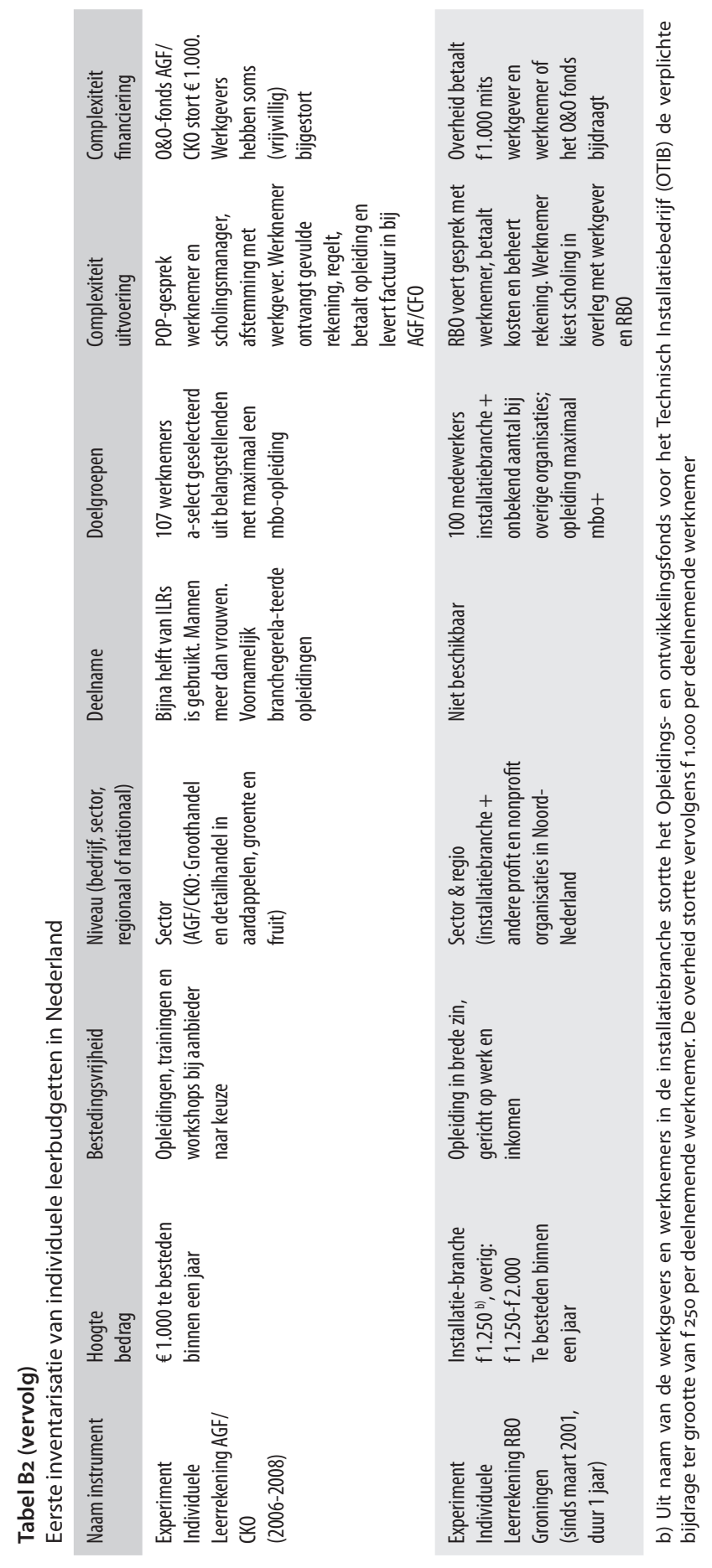




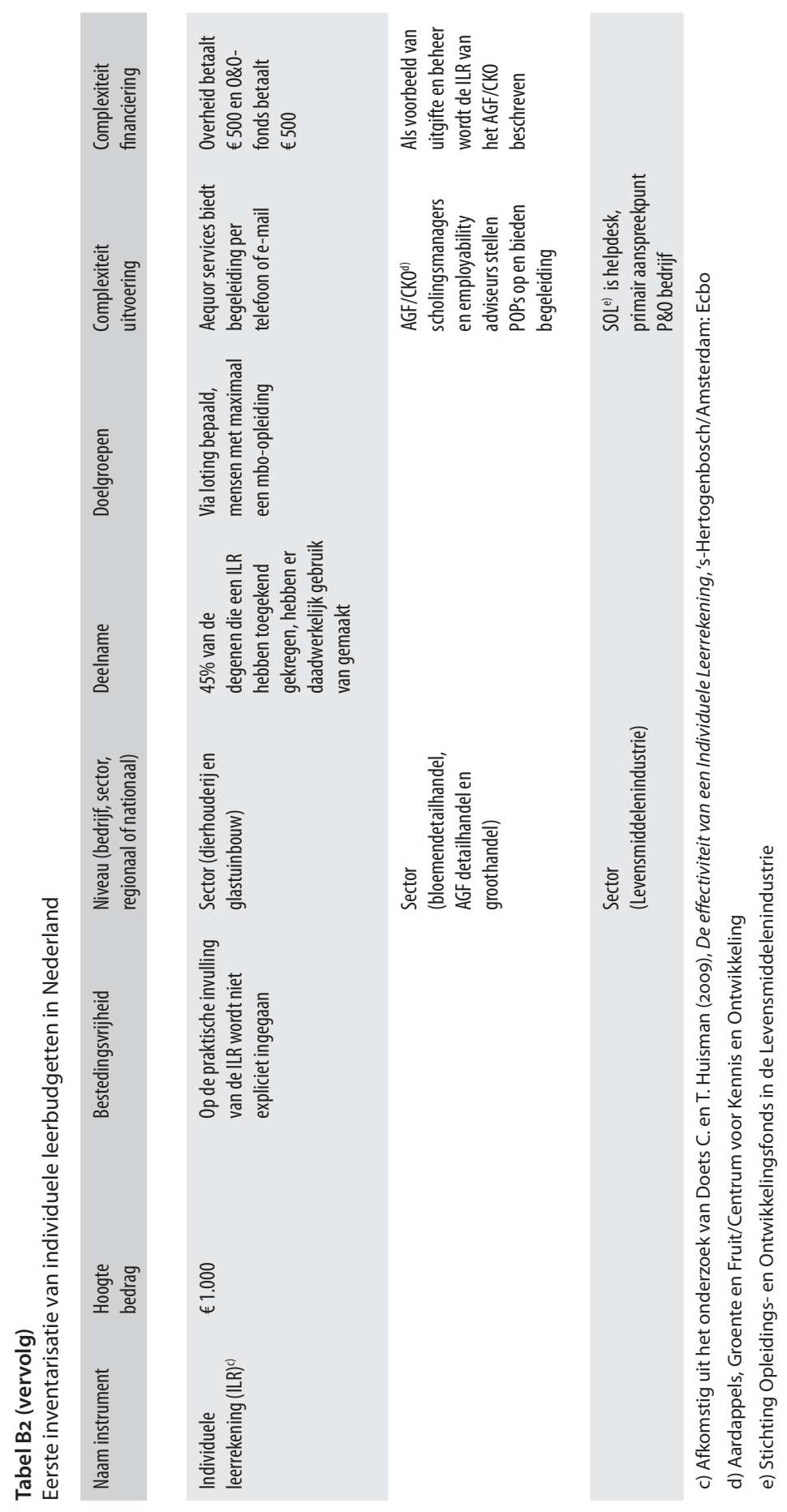




\section{Overzicht experts}

De informatie met betrekking tot de pilotprojecten in hoofdstuk 2 is deels mondeling aangeleverd door een aantal experts. Verder zijn enkele van de adviezen verwoord door enkele experts als leerpunten opgenomen in hoofdstuk 3. Tot slot is het conceptuitvoeringsmodel van de Ontwikkelingscheque met al deze experts besproken en heeft hun feedback mede geleid tot het uitvoeringsmodel zoals dat in hoofdstuk 4 is gepresenteerd.

\section{Naam}

Mevr. I. Ambos

Mevr. I. Coenen

Dhr. N. Fox

Dhr. H. de Groot

Dhr. R. Jaich

Dhr. F. Meijers

Dhr. J. Muth

Dhr. C. Schoenmakers

Mevr. A. Stel

Dhr. M. Stolwijk

Dhr. M. Tölle

Dhr. A. Verhoeff

Mevr. N. Wester

\section{Organisatie}

German Institute for Lifelong Learning

FNV Vakcentrale

Individual Learning Company, UK

Stichting Arbeidsmarkt en Opleiding in de Metalektro (A+O Metalektro)

Ver.Di - German Trade Union for Services

Sector

Meijers Onderzoek \& Advies

Gesellschaft für Innovative Beschaeftigung, NRW

Landelijk Overleg Scholingsfondsen (LOS) en Stichting AGF Centrum voor Kennis en Ontwikkeling (AGF/CKO)

Stichting Opleiding \& Ontwikkeling Flexbranche (STOOF)

Stichting AGF Centrum voor Kennis en Ontwikkeling (AGF/CKO)

Chamber of Labour Vienna/Austria Algemene Werkgeversvereniging Nederland (AWVN)

Provincie Noord-Brabant

Naast bovengenoemde experts hebben onderstaande personen informatie verschaft met betrekking tot de pilotprojecten Leertegoedbon (OOM), Employabilitybudget (ING) en de Philips E-miles beschreven in hoofdstuk 2:

\section{Naam}

Mevr. J. Janssen

Dhr. M. van het Schip

Dhr. W. Daalder

Dhr. R. Gerards

\section{Organisatie}

Opleidings- en Ontwikkelingsfonds voor de Metaalbewerking (OOM)

Opleidings- en Ontwikkelingsfonds voor de Metaal-bewerking (OOM)

ING

Universiteit Maastricht 
BIJLAGEN

\section{Tabel B3}

Budgettair beslag van huidige maatregelen in 2010

in miljoenen euro's

\begin{tabular}{llc}
\hline Werkgevers & Wet Vermindering Afdracht onderwijs, categorie EVC & 5,2 \\
\hline Werknemers & Inkomstenbelasting studiekosten & 180 \\
& Spaarloon & 207 \\
& Levensloop & 199 \\
\hline & & 53,3 \\
\hline Overig & ESF-subsidies actie D & $?$ \\
\hline & 1400 regelingen & 644,5
\end{tabular}

Bron: Ministerie van Financiën (2010) 